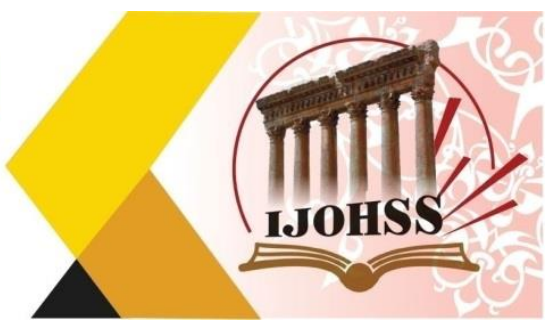

\title{
جريمة القتل بالسلاح الناري الكاتم للصوت (دراسة مقارنةً)
}

سعد عبد الواحد حمزه

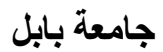

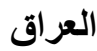

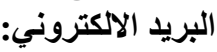
saadalzaman919@gmail.com

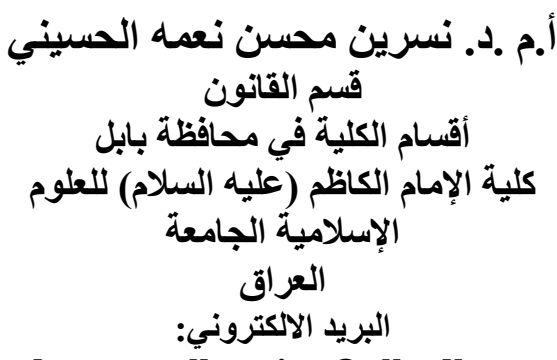

drnsreenalhusainy@alkadhumcol.edu.iq

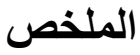

تعد جريمة القتل من ابشع الجر ائم التي عرفتها البشرية و التي حاربتها الثريعة الاسـلامية و القوانين الوضعية

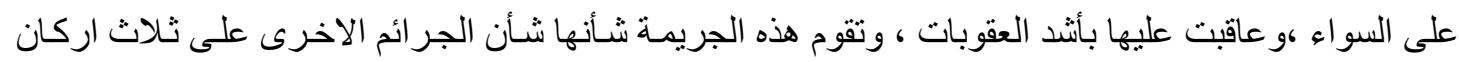

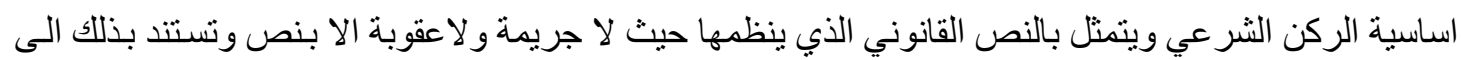
المواد ( 405 ، 406 ) من قانون العقوبات العر اقي رقم 111 لسنة 1969 المعدل بحسب القو اعد العامة وسواء

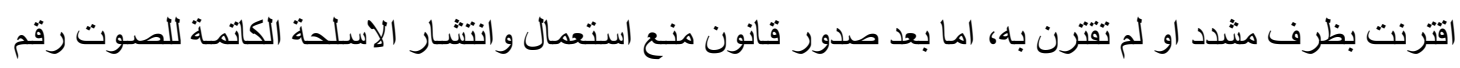

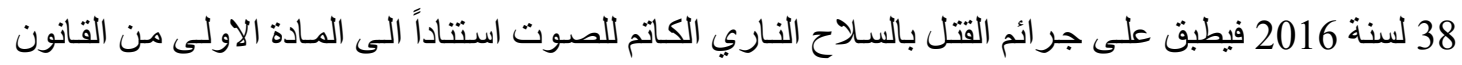

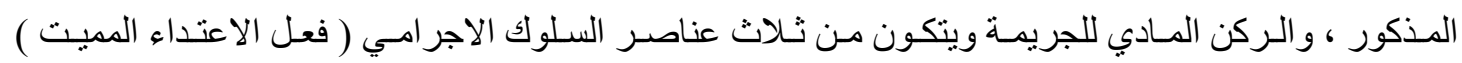
و النتيجة الجرمبة ( الوفاة ) و العلاقة السببية بينهـا ، امـا الركن المعنوي فيأخذ صسورة (القصد الجرمي ) لان الجريمة عمدية تقوم على اساس القصد العام بعنصرية العلم و الار ادة ، وتعد جريمـة القتل بالسـلاح النـاري الكاتم

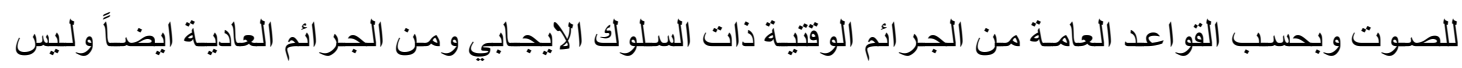

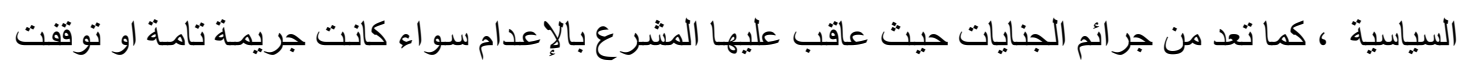

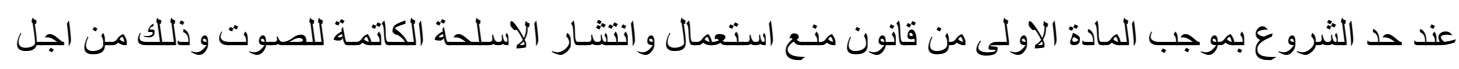

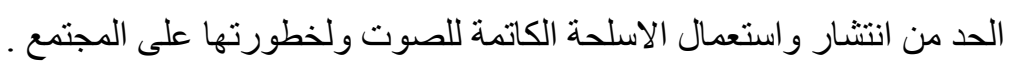
الكلمات المفتاحية: جريمة القتل، السلاح الناري الكاتم للصوت، كاتمات، مخفضات الصوت. 


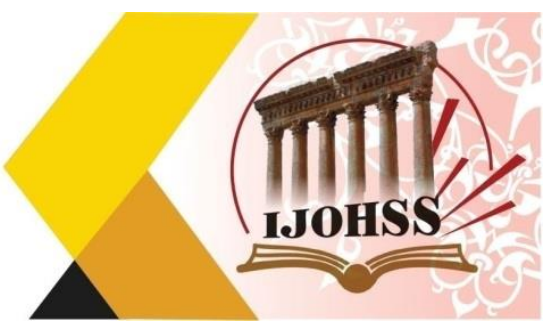

\title{
Murder with a Silenced Firearm (A comparative study)
}

\author{
Dr. Nasreen Mohsen Naama Al - \\ Husseini \\ Department of Law \\ College Sections in Babil Governorate \\ Imam Al - Kadhim College of Islamic \\ Sciences \\ Iraq \\ drnsreenalhusainy@alkadhum- Email: \\ col.edu.iq
}

\author{
Saad Abdul Wahed Hamza \\ University of Babylon \\ Iraq
}

Email: saadalzaman919@gmail.com

\begin{abstract}
The crime of murder is one of the most heinous crimes known to mankind, which was fought by Islamic Sharia and man-made laws alike, and punished with the most severe penalties. $(405,406)$ of the Iraqi Penal Code No. 111 of 1969 amended according to the general rules and whether or not accompanied by an aggravating circumstance, but after the issuance of Law No. 38 of 2016 prohibiting the use and proliferation of silenced weapons, it is applied to murder crimes with silenced firearms based on the The first article of the said law, The material element of the crime consists of three elements of the criminal behavior (the act of fatal assault), the criminal consequence (death) and the causal relationship between them. According to the general rules, it is temporary crimes with positive behavior and ordinary crimes as well as not political ones. It is also considered one of the felonies crimes where the legislator punished it with the death penalty, whether it was a complete crime or stopped at the threshold of initiation according to Article 1 of the Law on Preventing the Use and Spread of Silent Weapons, in order to Reducing the spread and use of silenced weapons and their danger to society.
\end{abstract}

Keywords: murder, silencer firearms, silencers, sound reducers. 


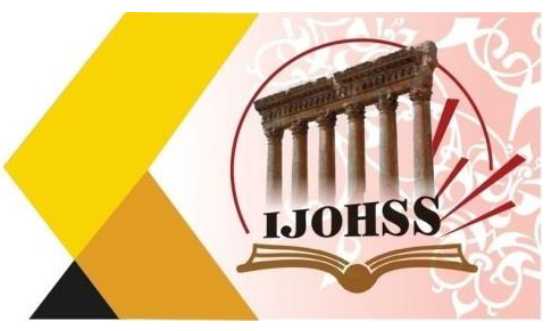

المقدمة

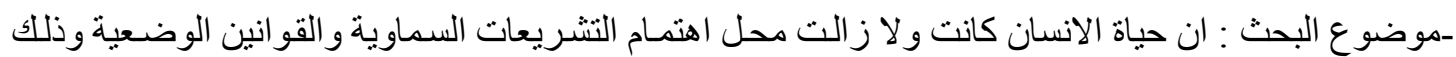

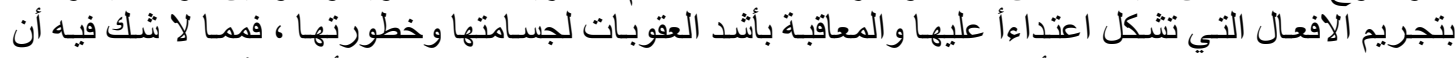

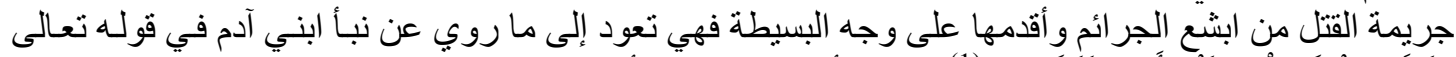

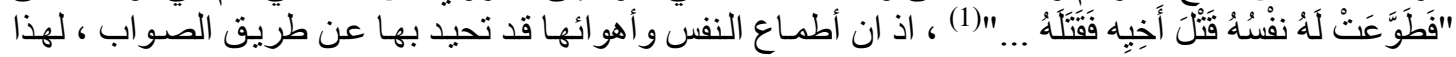

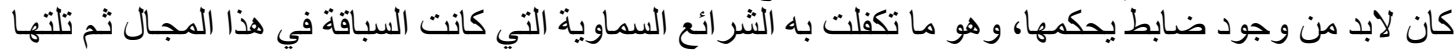

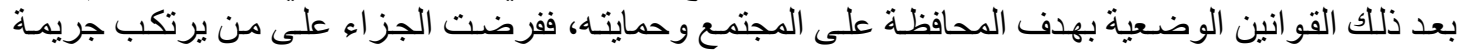

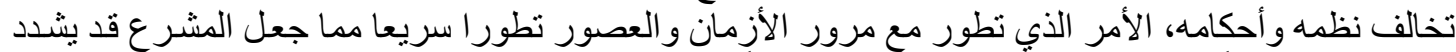

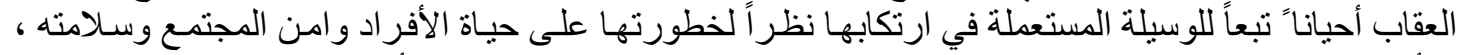

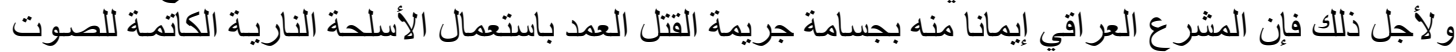

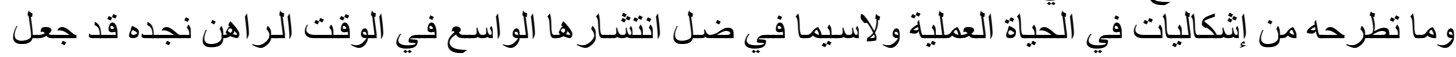

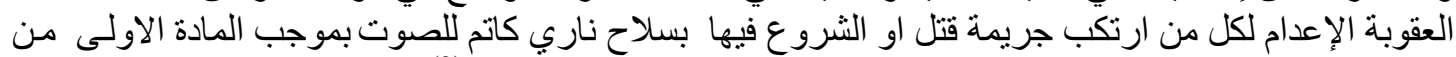

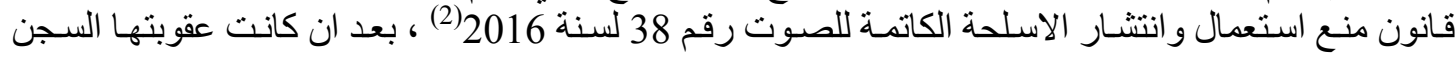

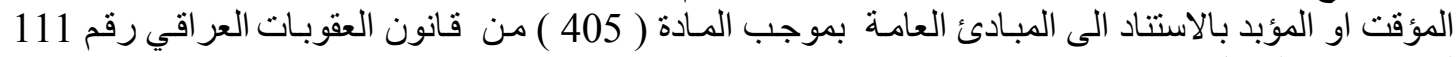
لمينة 1969 المعدل. ـمشكلة البحث: يثير موضول البثوع البحث الكثير من الاسئلة لعل اهمها مـا هو سبب تمييز جريمـة القتل باستعمال

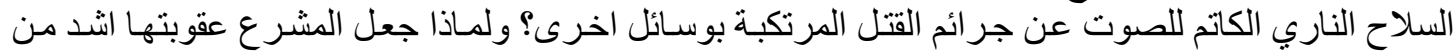

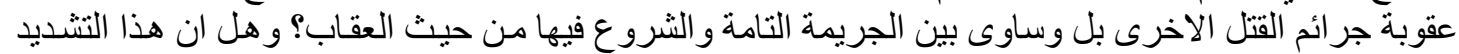

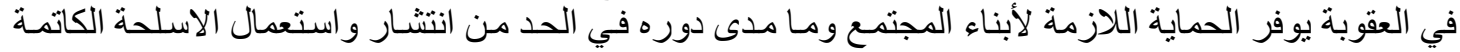

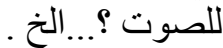

ـمنهج البحث: اعتمد البحث منهجا تحليليا مقارنا لكونه المنهج الأكثر انسجاما مع موضوع البه البحث.

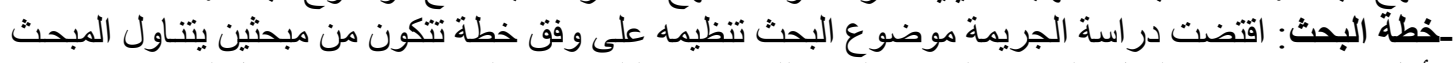

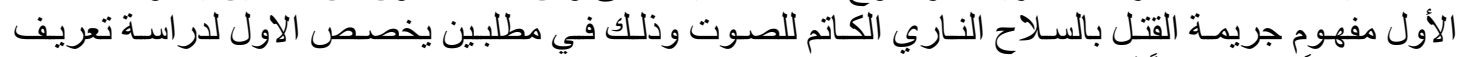

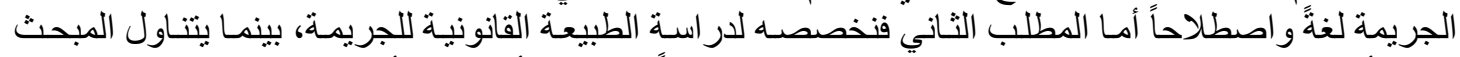

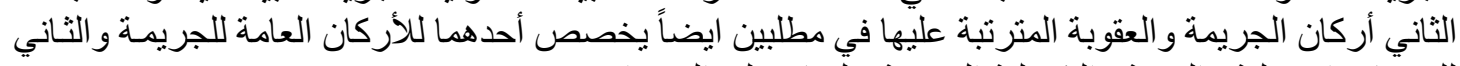

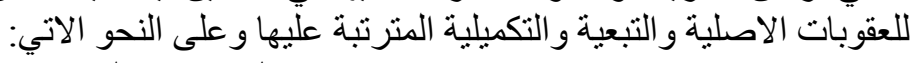

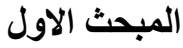

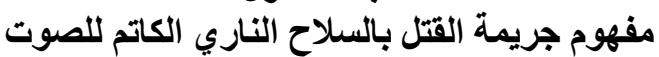

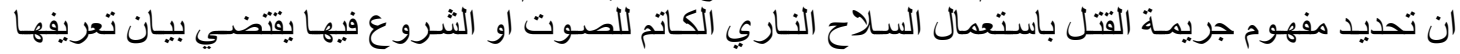

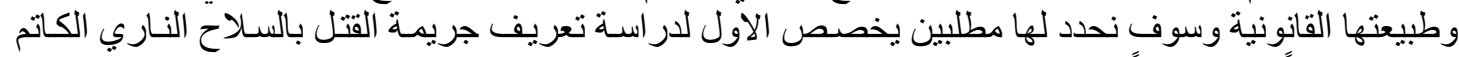

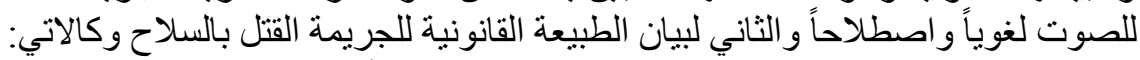

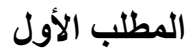

تعريف جريمة القتل بالسلاح الناري الكاتم للصوت اللإن

لغرض تعريف الجريمة لابد من بيان المعنى اللغوي و الاصطلاحي لها وذلك من خلال الفر عين الآتيين:

\section{الفرع الاول

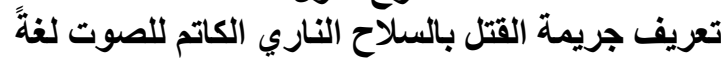

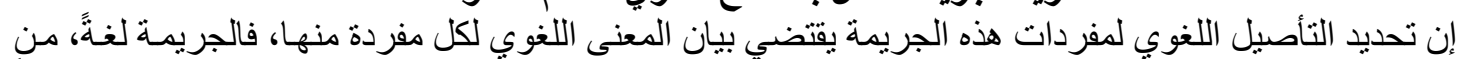

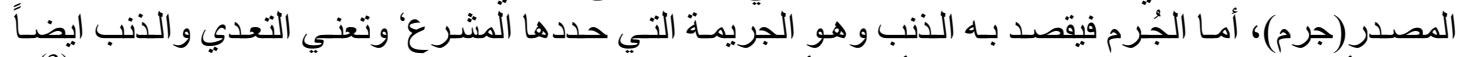

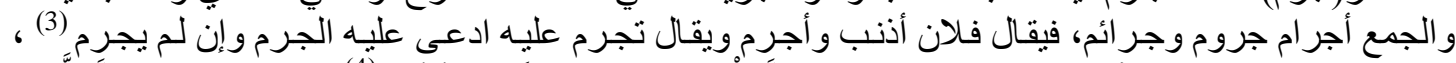

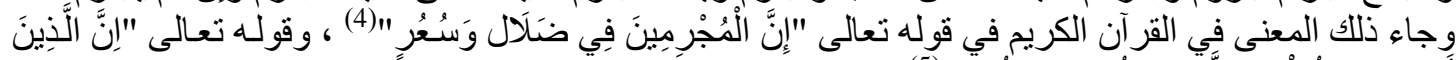

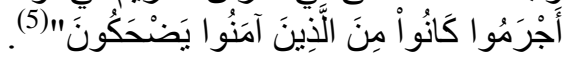




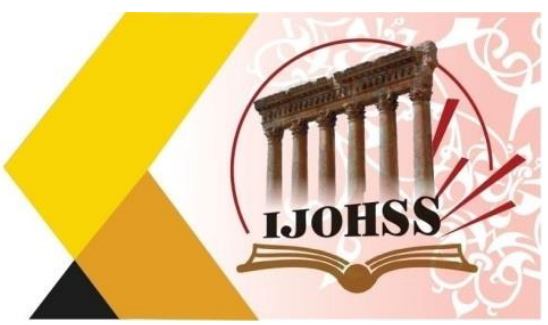

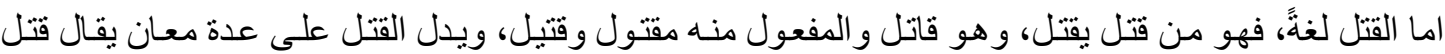

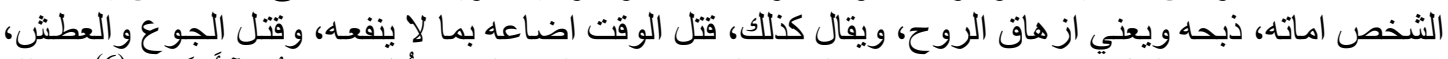

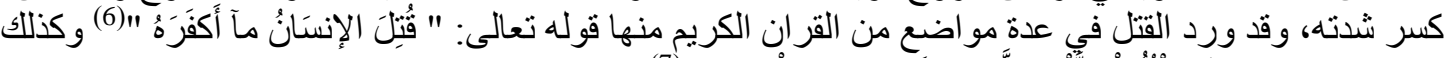

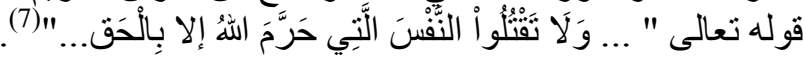

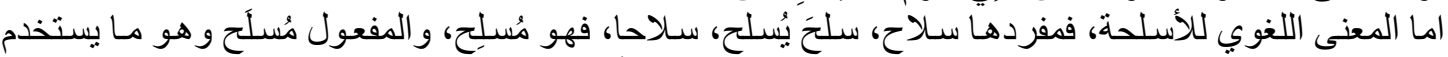

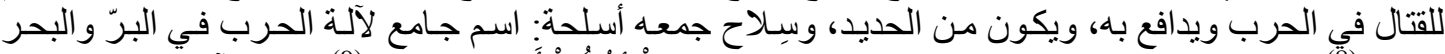

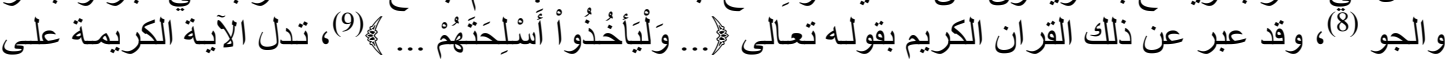
وجوب اخذ الاسلحة التي يتقوى بها المسلمين على الاعداء، ويقال اخذ القوم اسلحتهم أي كل و احد سلاحه، وتسلح

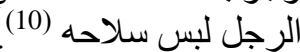

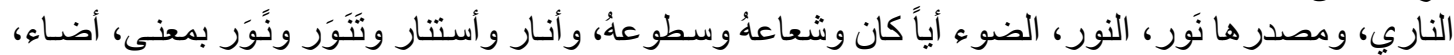

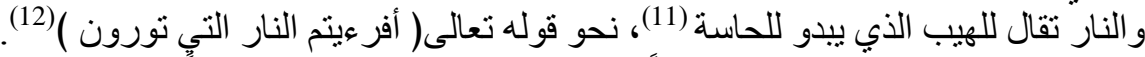

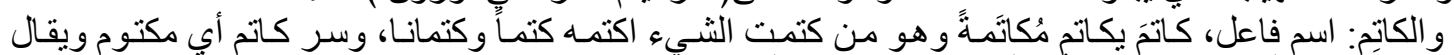

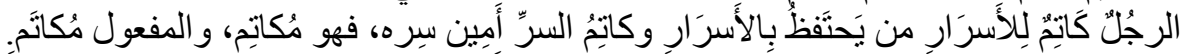

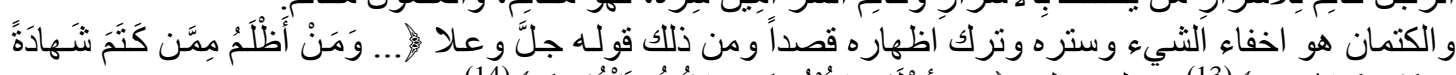

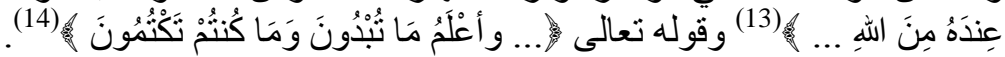

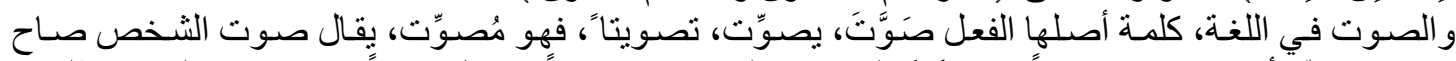

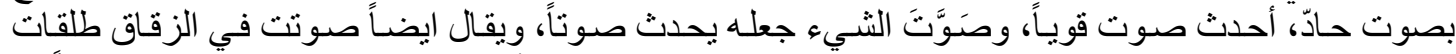

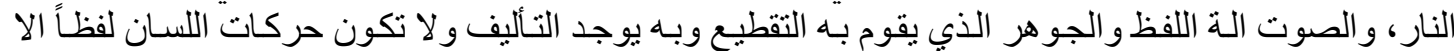

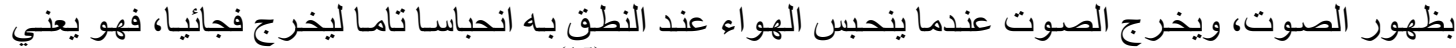
الذبذبات الهو ائية الناتجة مباشرة عن الهرت الحركات والاوضاع المبر المختلفة (15).

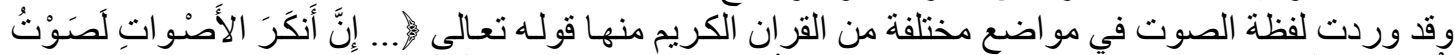

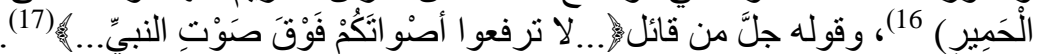
الفرع الثراني

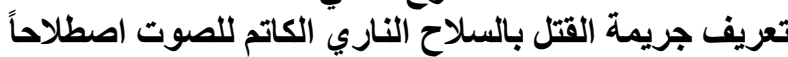

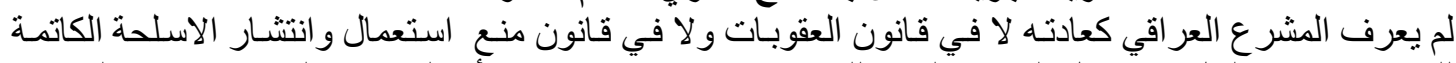

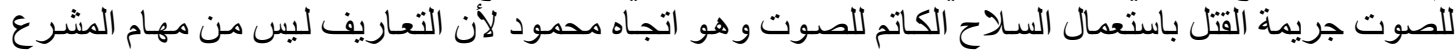

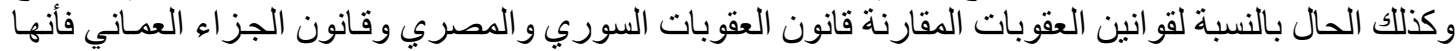

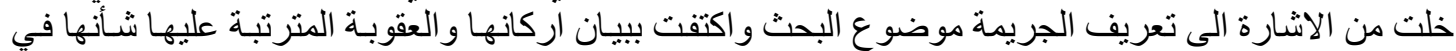

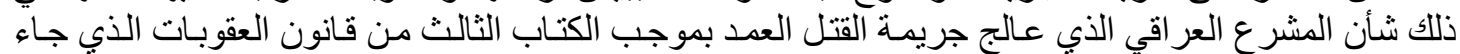

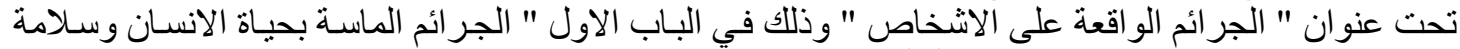

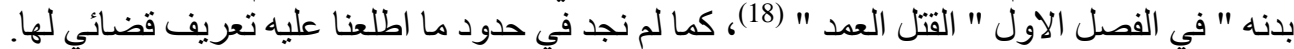

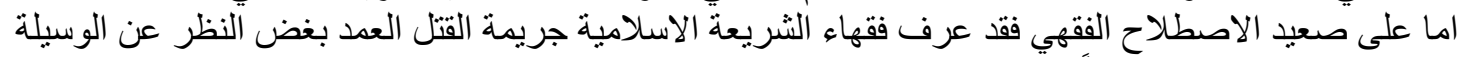

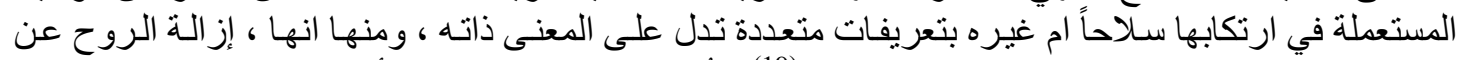

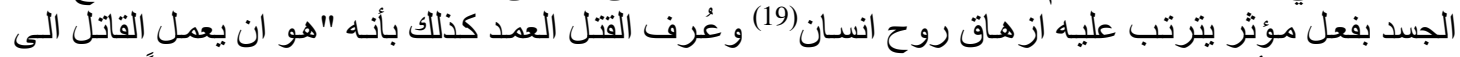

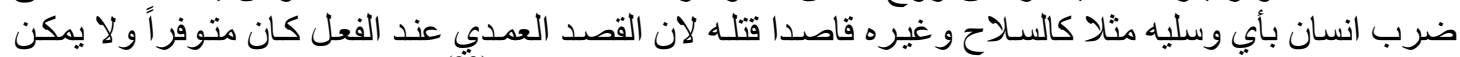

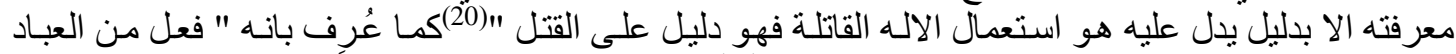

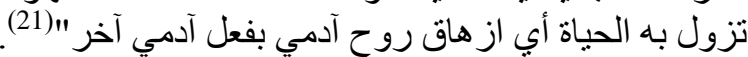

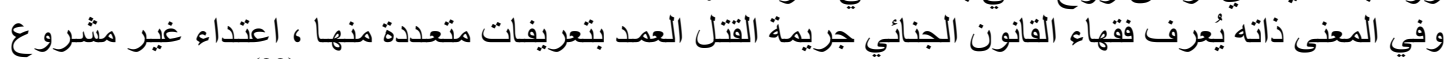

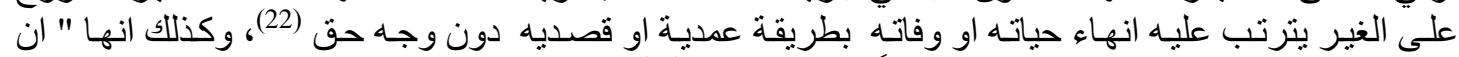

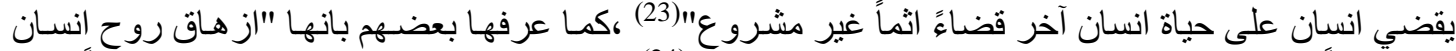

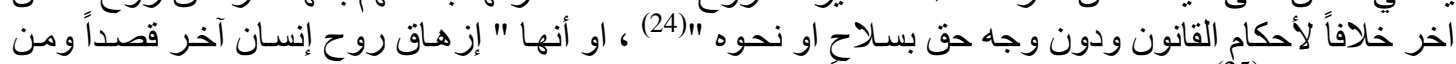

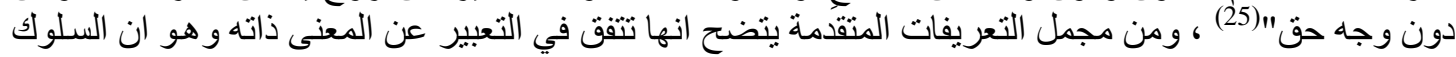




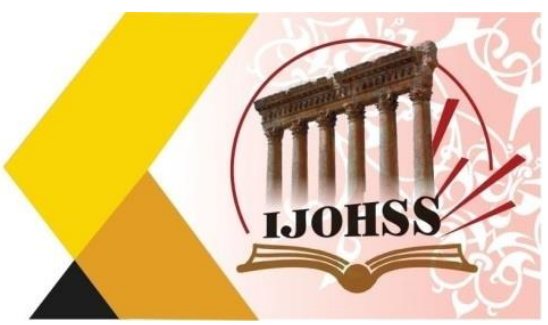

الاجر امي المكون للركن المادي لجريمة القتل العمد وبغض النظر عن الوسيلة المستعملة في ارتكابه وطبيعته

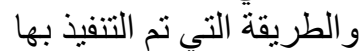

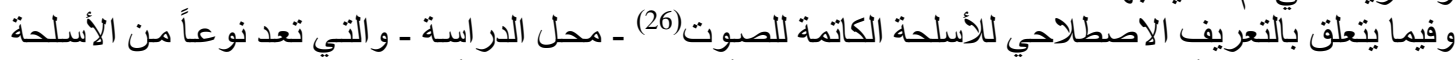

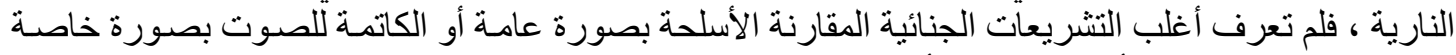

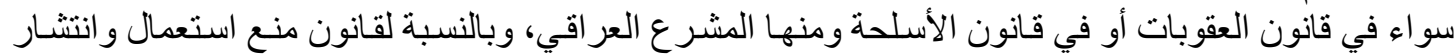

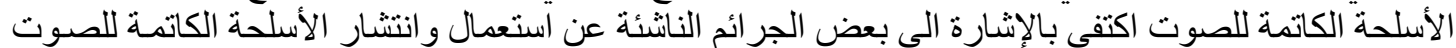

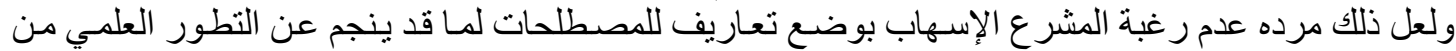

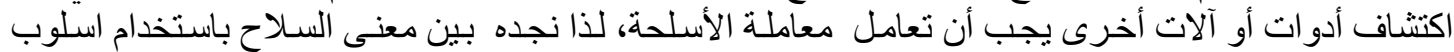

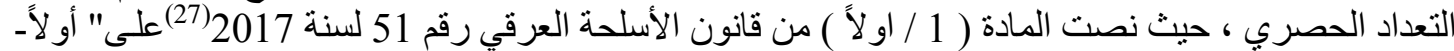

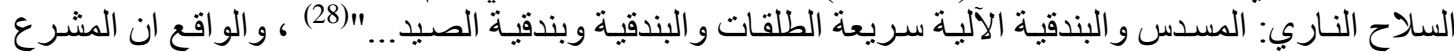

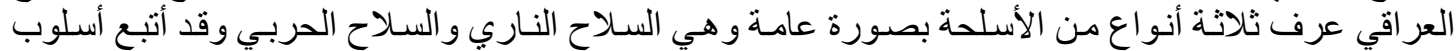

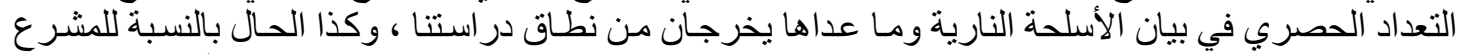

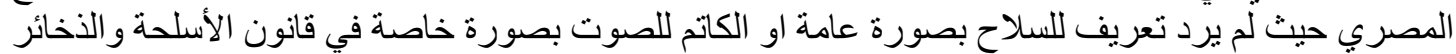

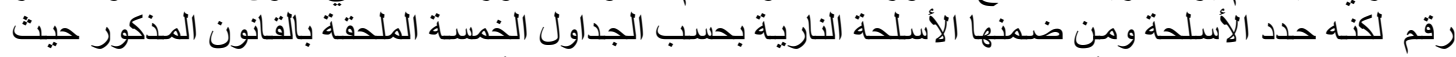

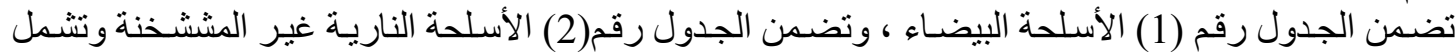

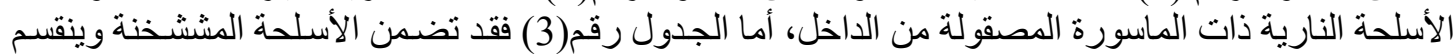

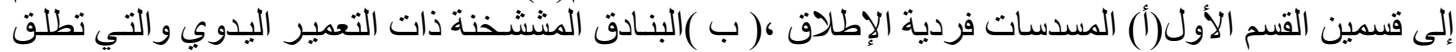

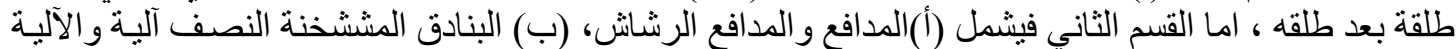

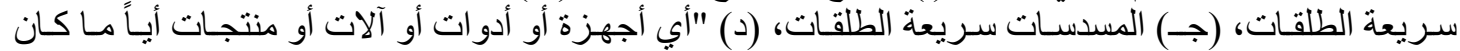

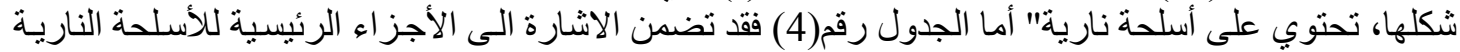

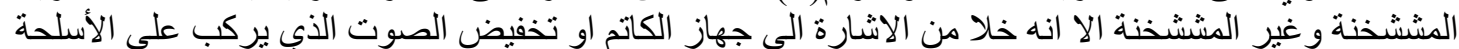

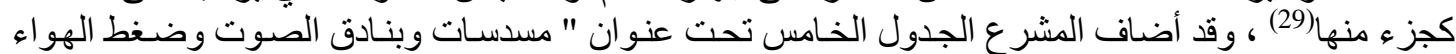

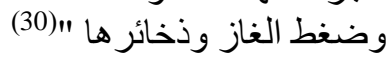

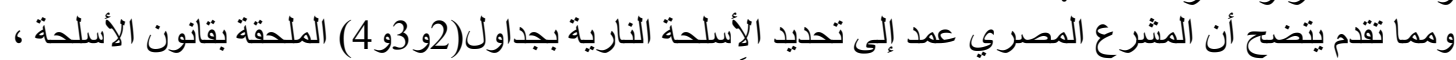

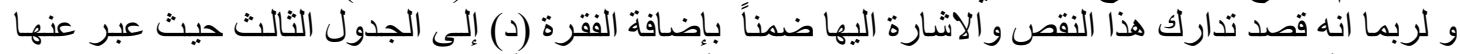

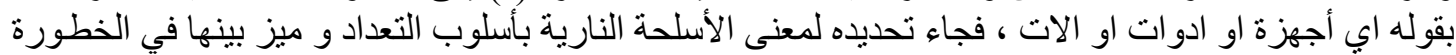

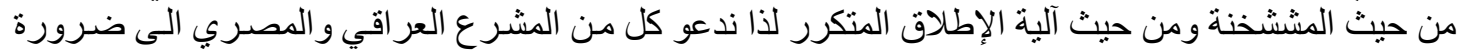

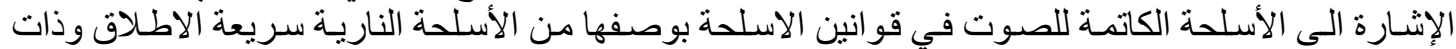

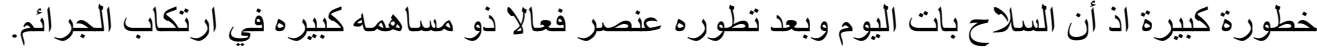

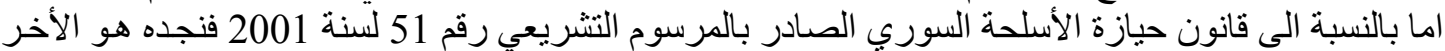

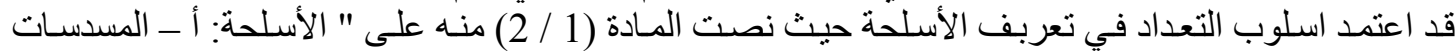

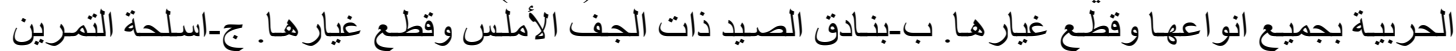

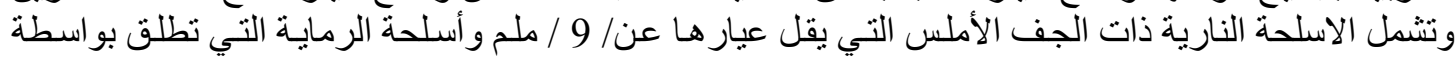

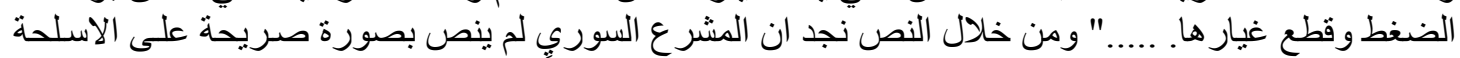

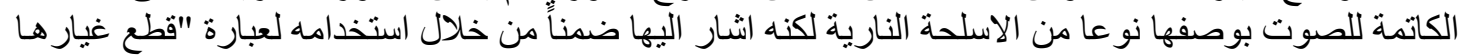

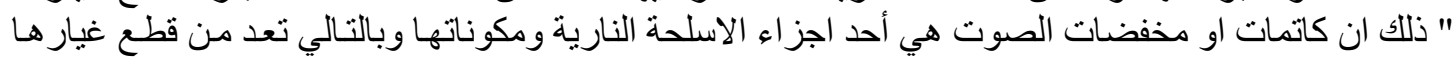

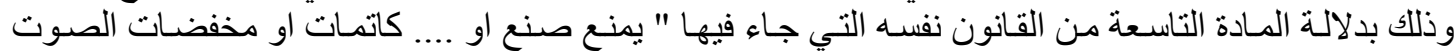
و والمناظير التي تركب على الأسلحة ....

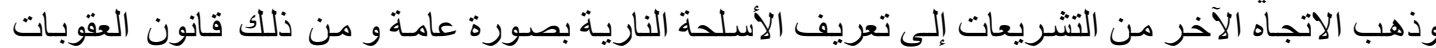

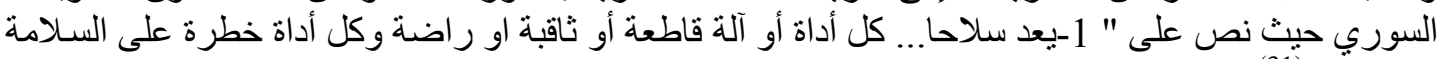

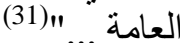

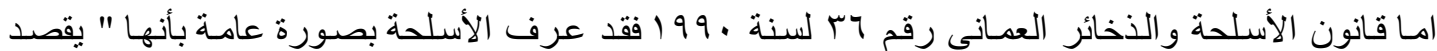

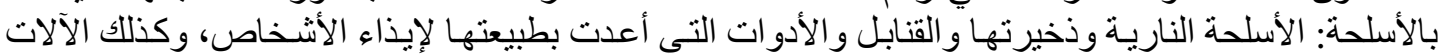




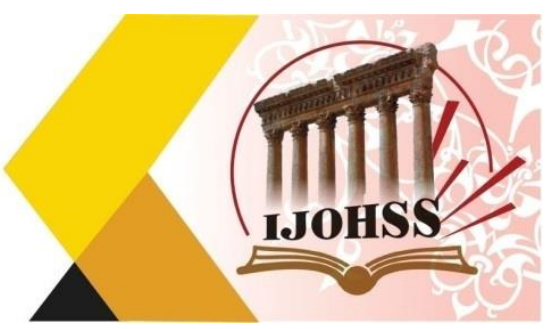

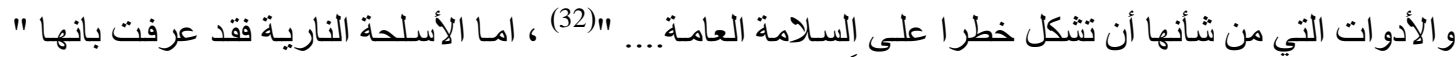

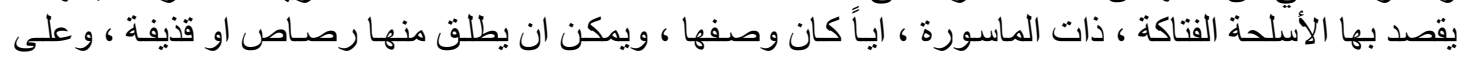

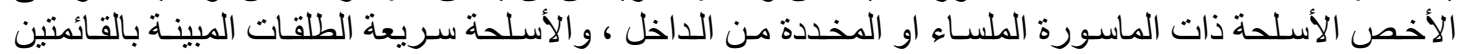

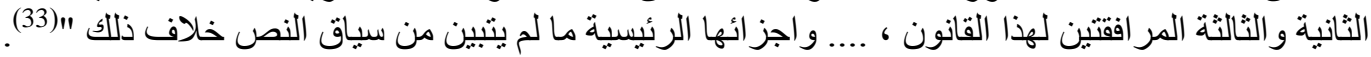

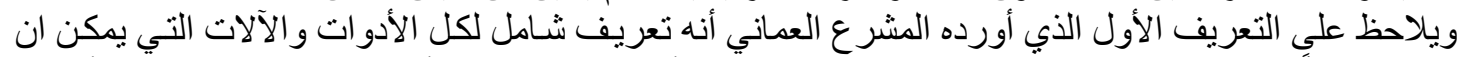

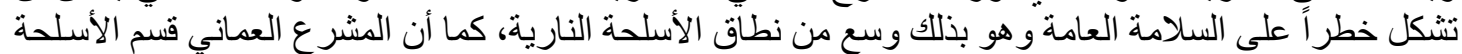

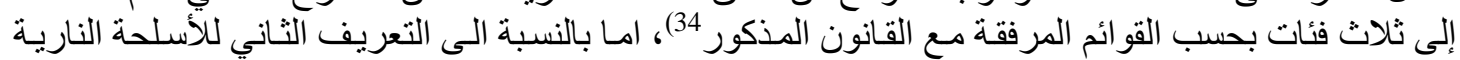

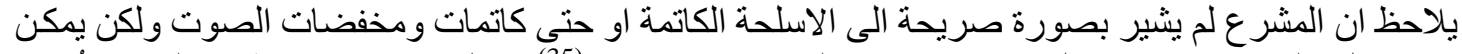

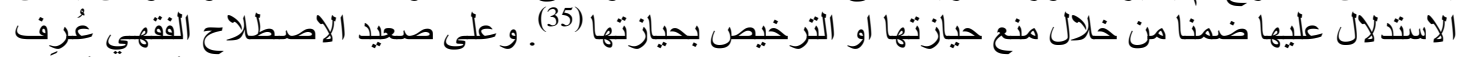

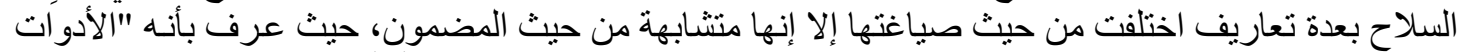

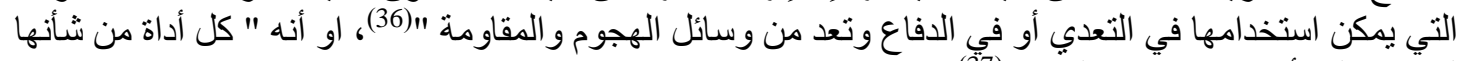

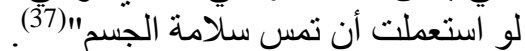

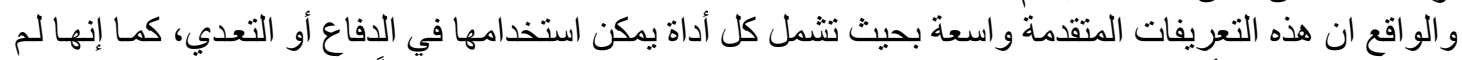

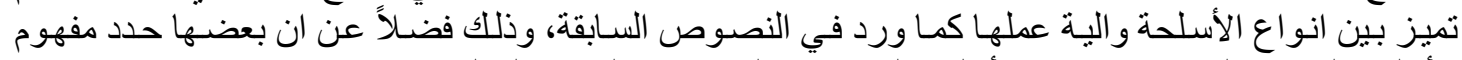

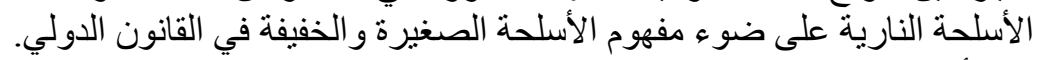

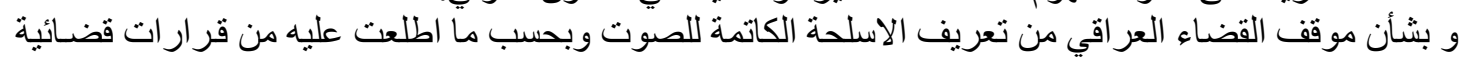

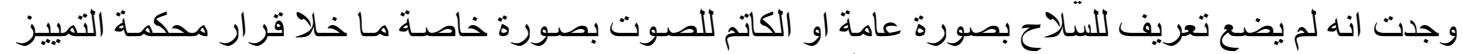

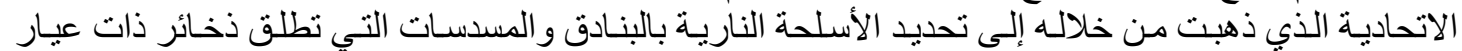

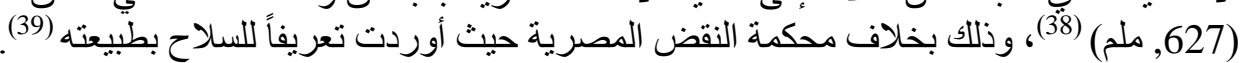

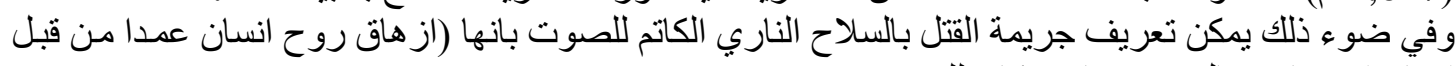
انسأن اخر باستعمال سلاح ناري كاتم للصوت فئر).

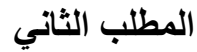

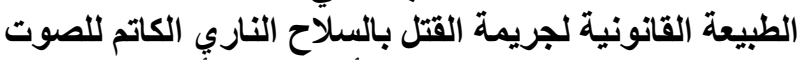

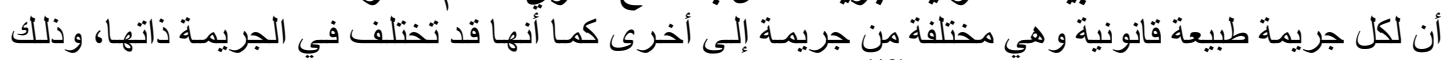

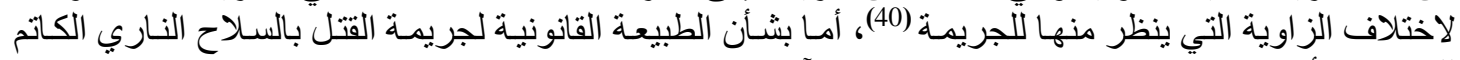

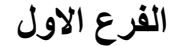

للصوت، فأنها تتميز بطيبعة خاصنة يمكن بيانها بالآتي:

\section{من حيث نوع السلوك الإجرامي وتوقيته}

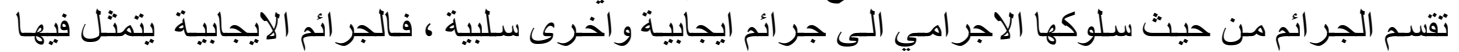

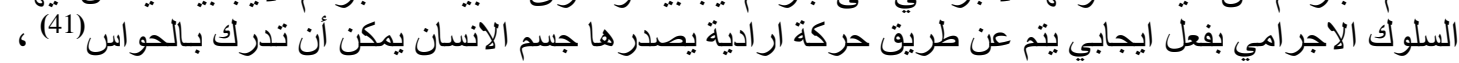

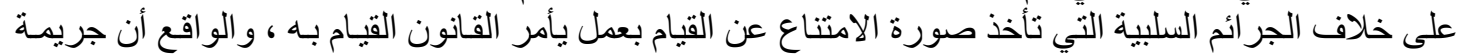

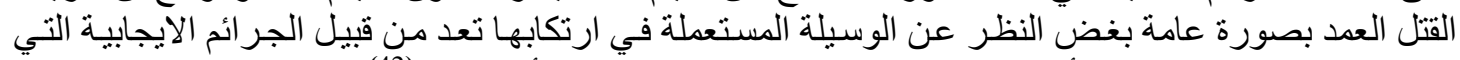

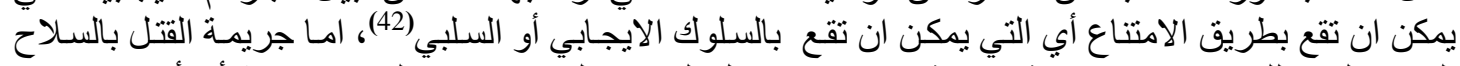

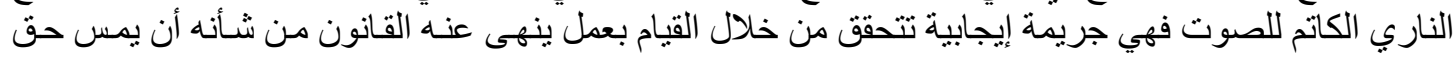

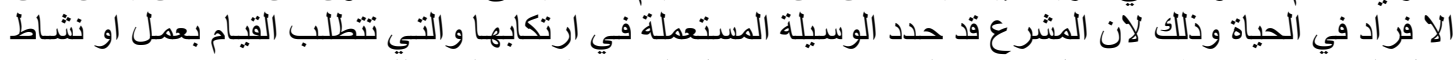

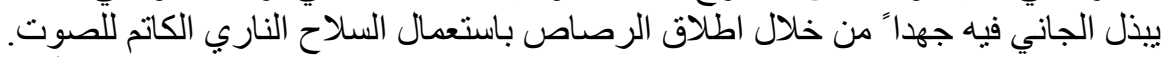

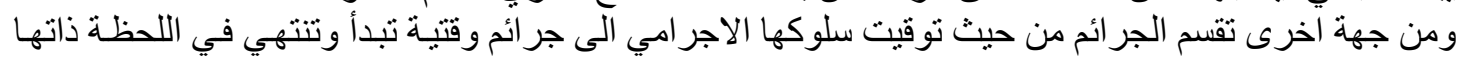

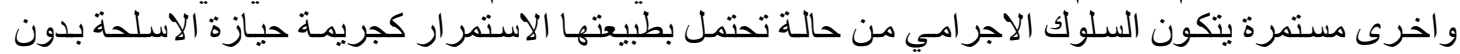

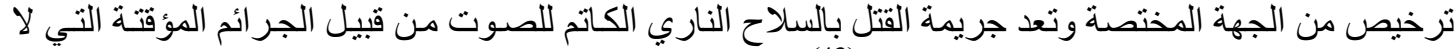
تحتاج الى وقت طويل لتنفيذ سلوكها الاجر امي (43). 


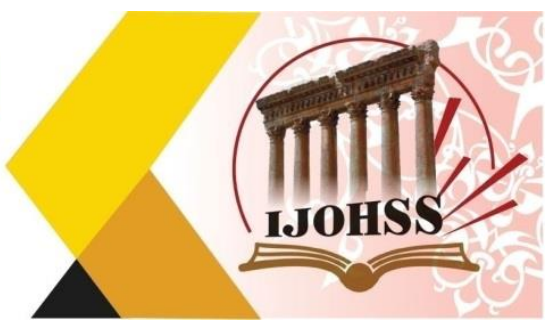

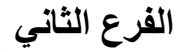 \\ من حيث تجريم السلوك أو النتيجة التئة}

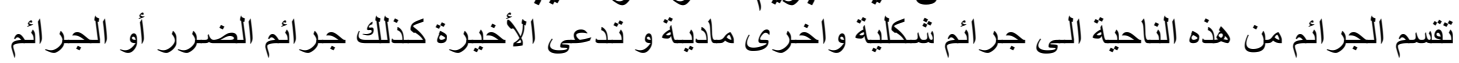

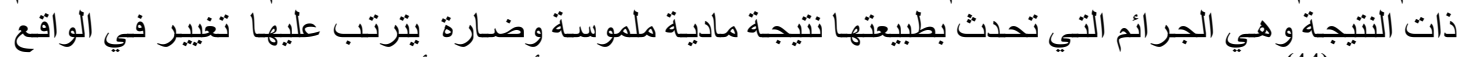

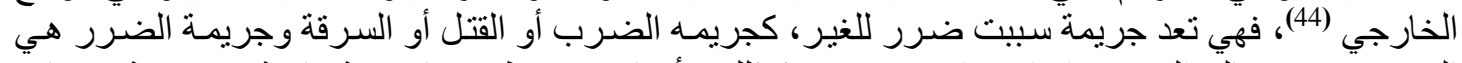

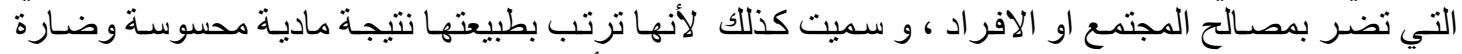
كعنصر من عناصر الركن المادي لها ، التي تتمثل بإحداث الوفاة أي إزهاق الروح في جريمة القتل باستعمال

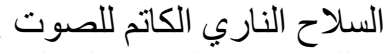

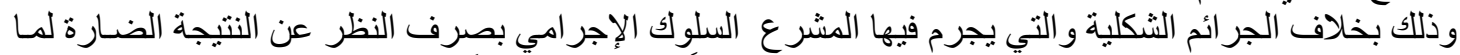

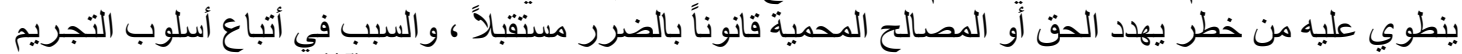

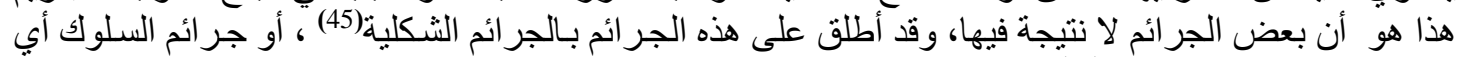

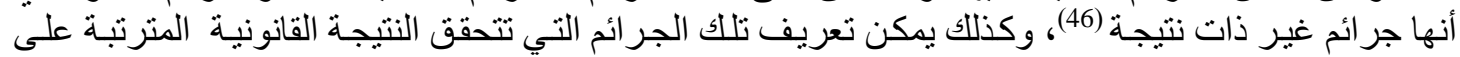

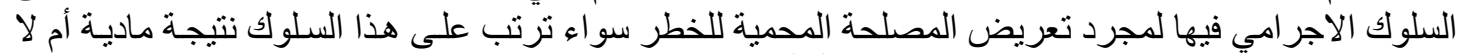

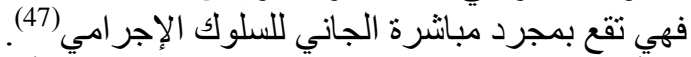

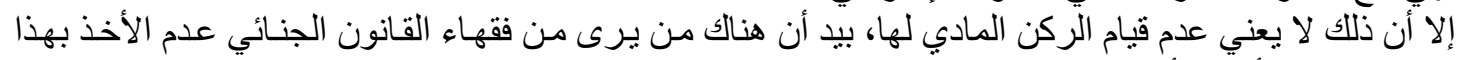

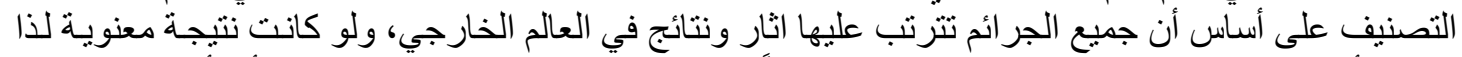

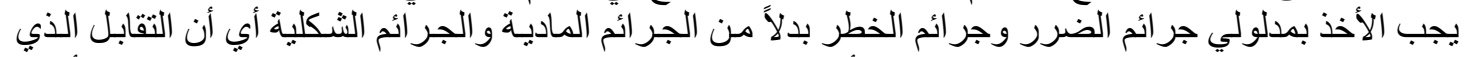

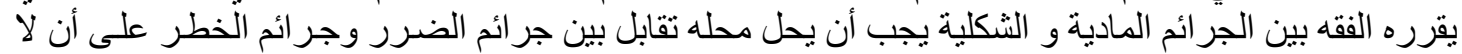

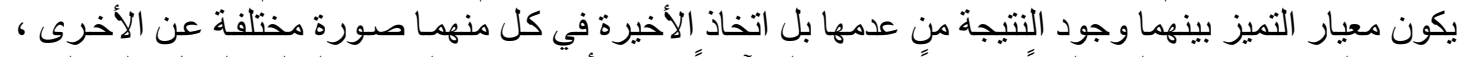

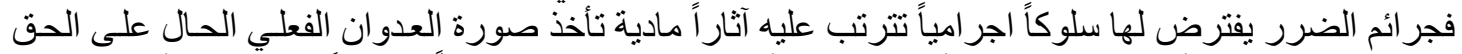

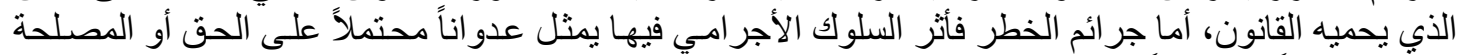

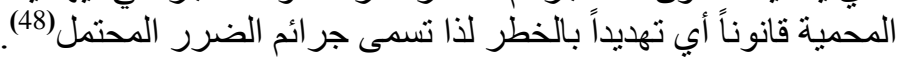

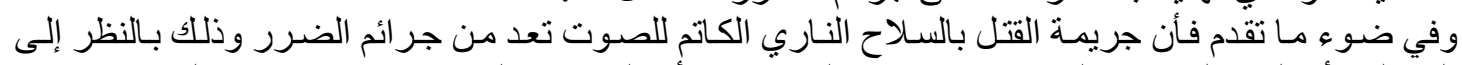

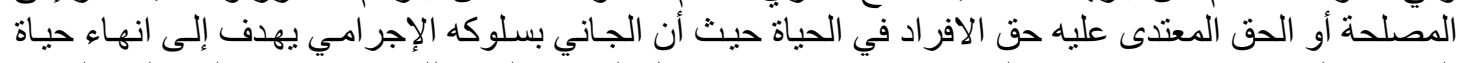

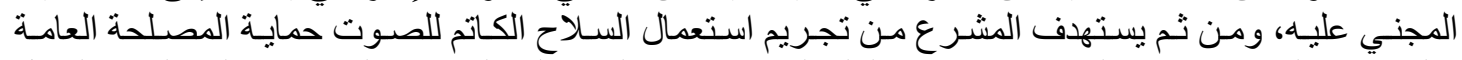

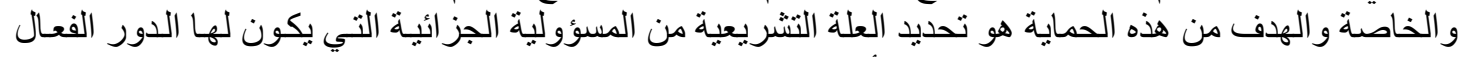

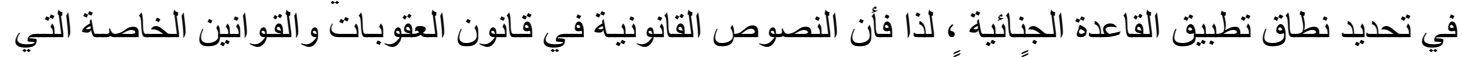

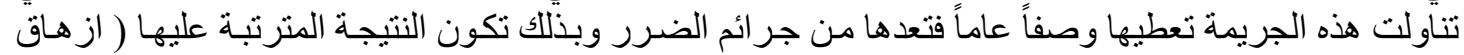

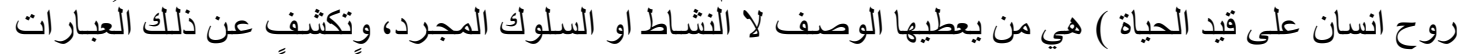

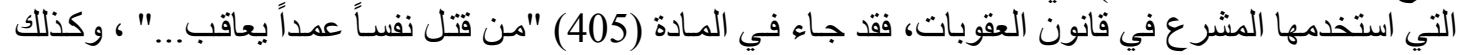

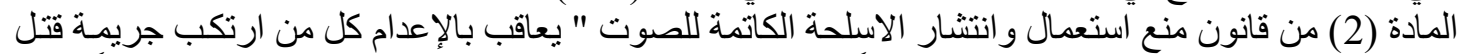

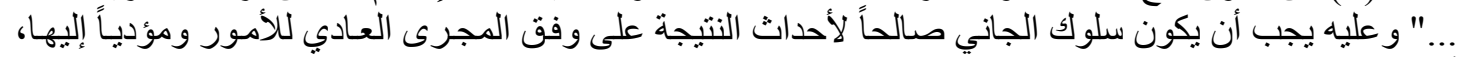

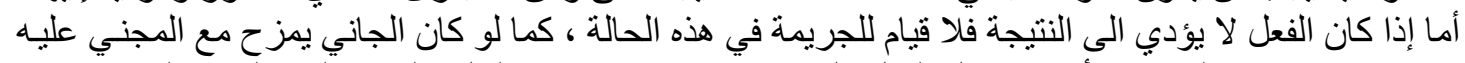

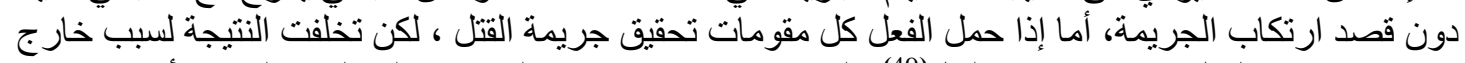

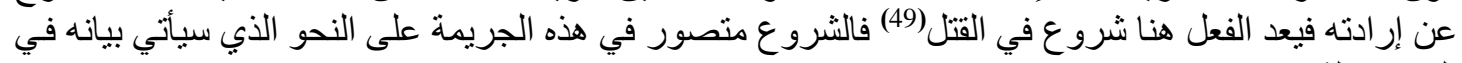

\section{الفرع الثالث}

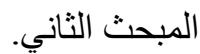

\section{من حيث الآثار المترتبة عليها}

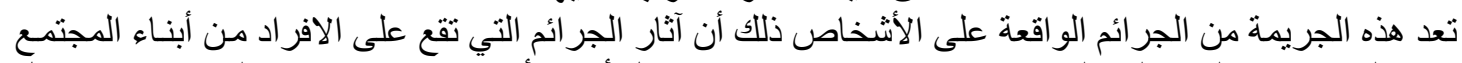

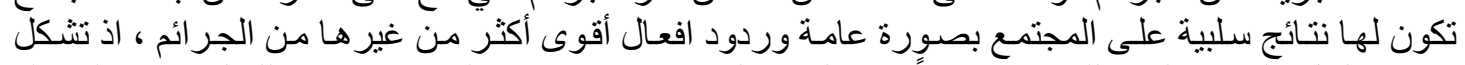

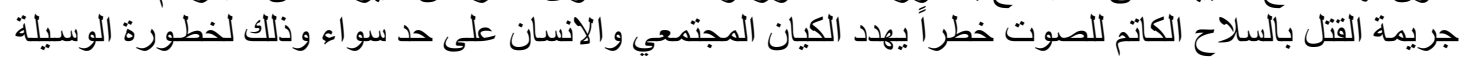

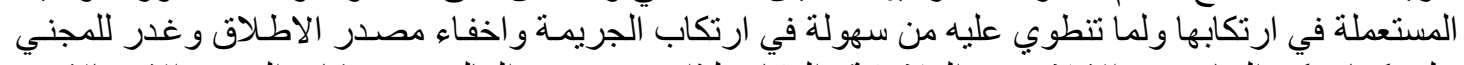

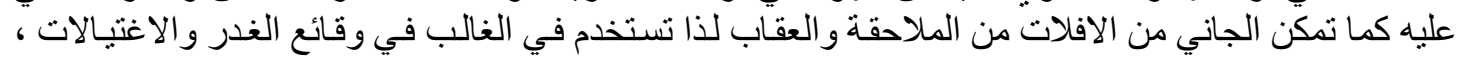




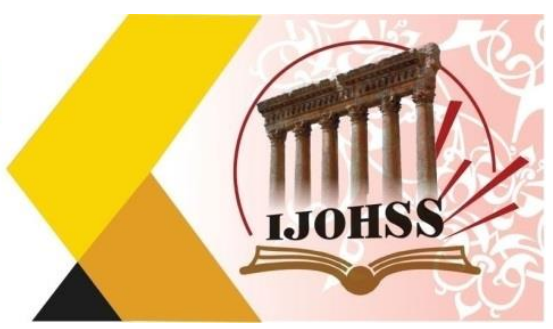

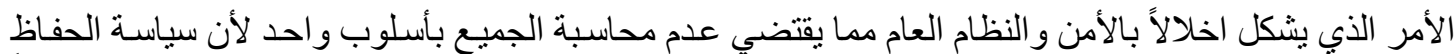

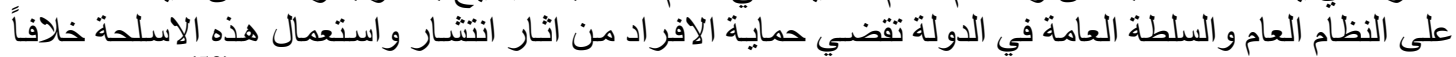

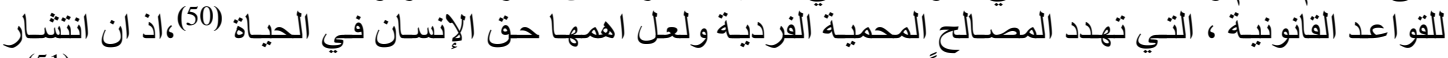

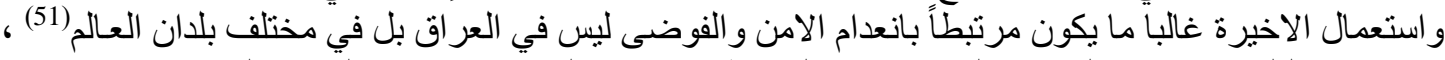

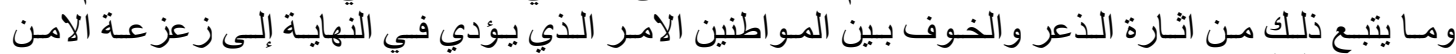

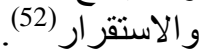

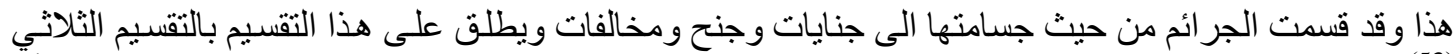

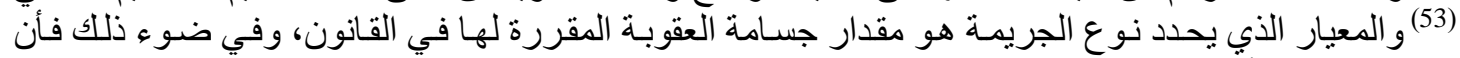

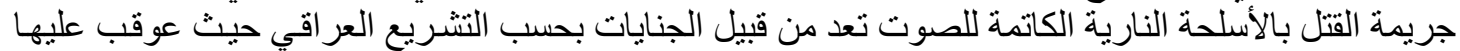

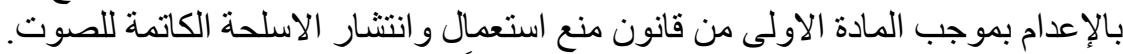

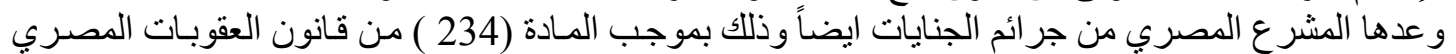

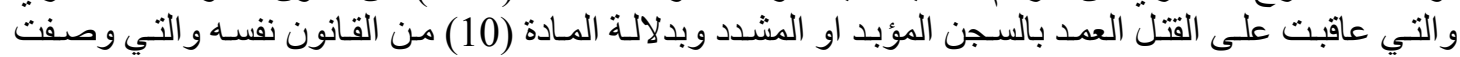

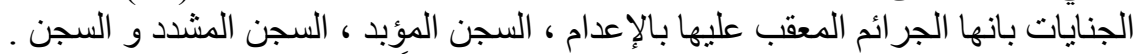

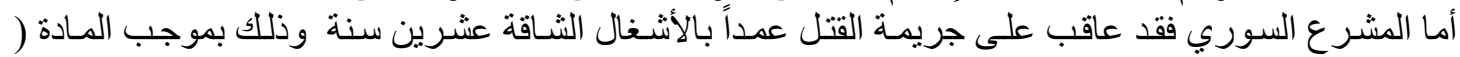

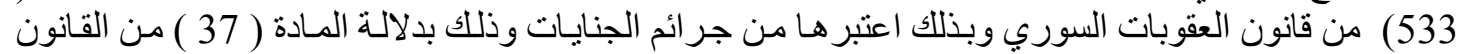

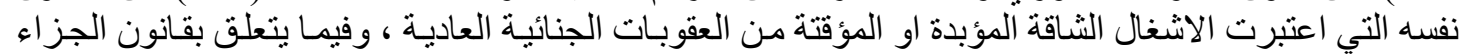

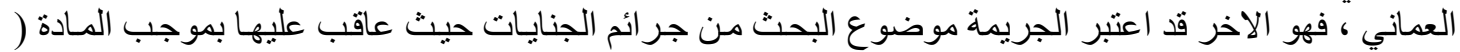

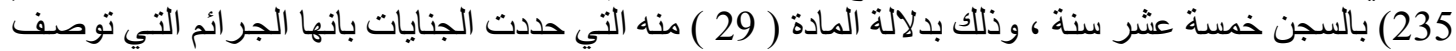

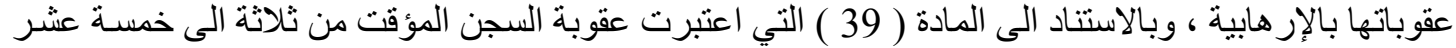

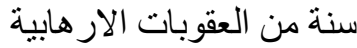

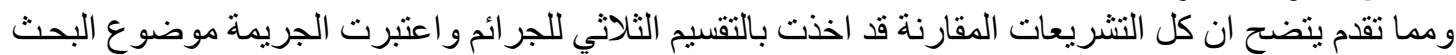

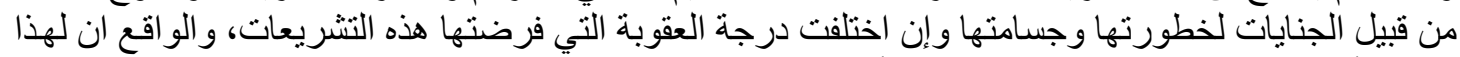

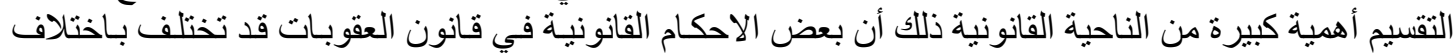

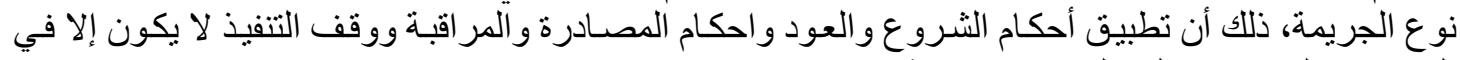
الجنايات والجنح دون المخالفات إلا ما استثني بنص النص خاص.

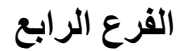

\section{من حيث كونها جريمة سياسية ام عادية الفية الرية}

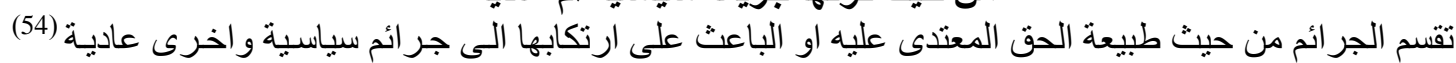

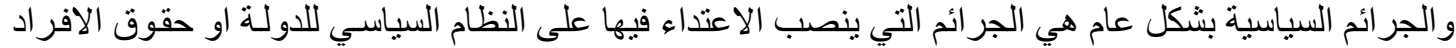

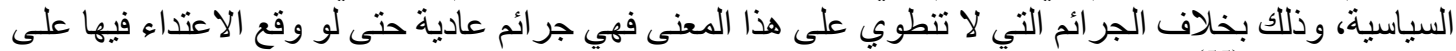
الافر اد أو الدولة (55) التئن

وقد ظهرت نظريتين في تحديد المعيار الفاصل بين الجريمة السياسية والجريمة العادية وهما:

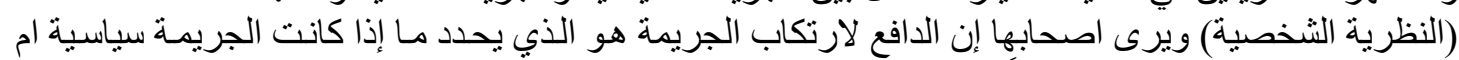

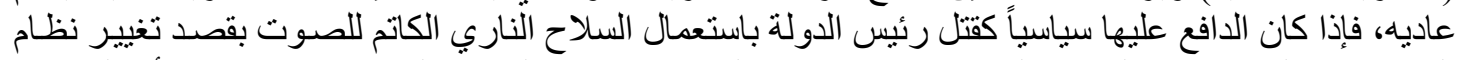

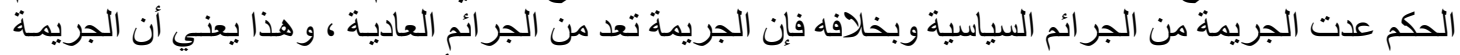

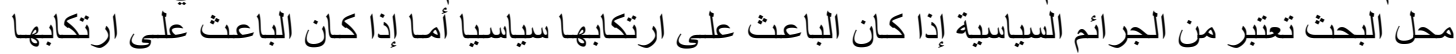

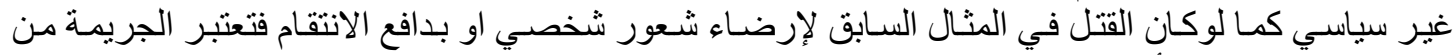

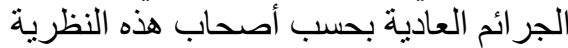

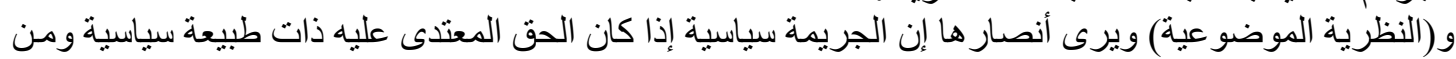

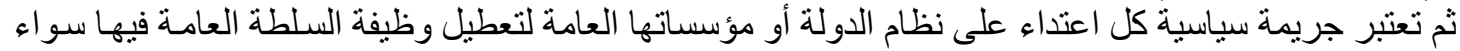

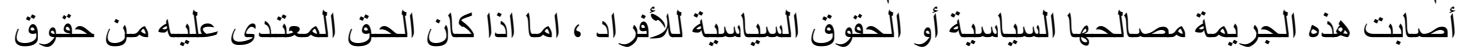

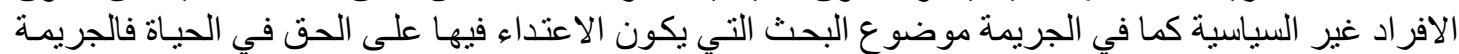

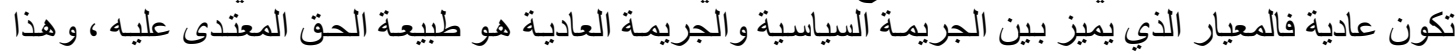




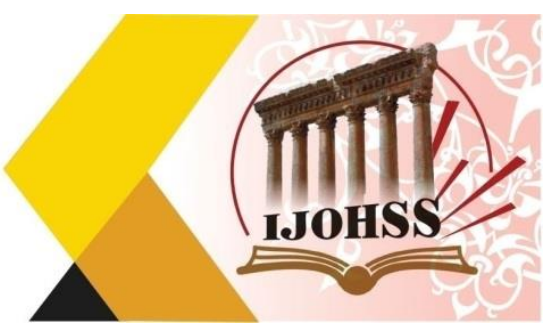

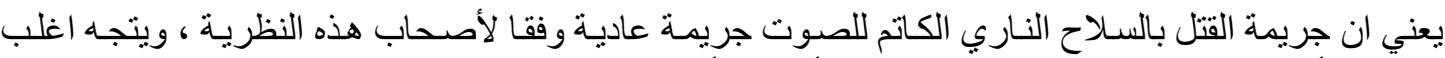

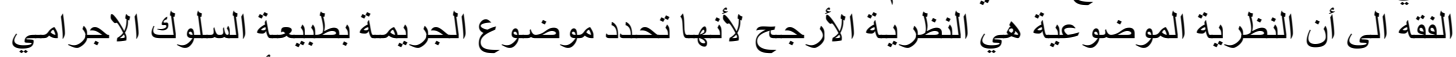

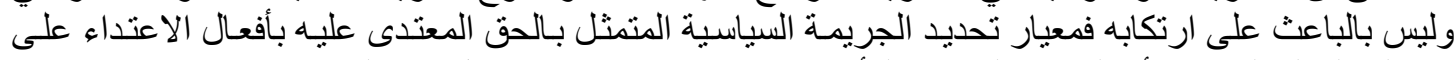

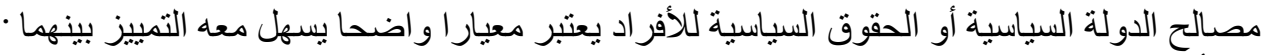

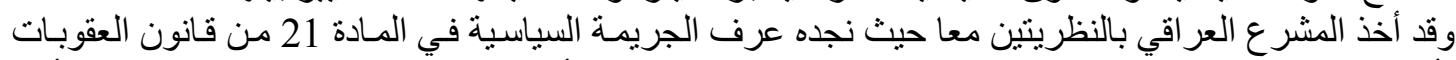

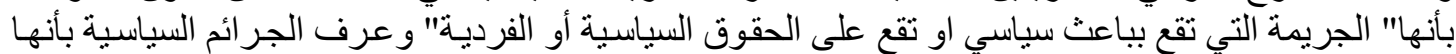

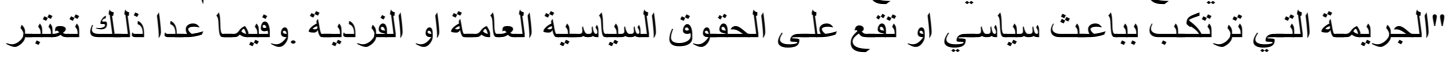

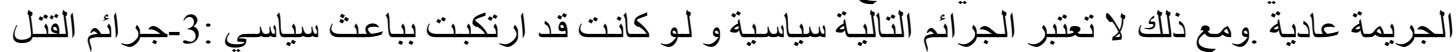

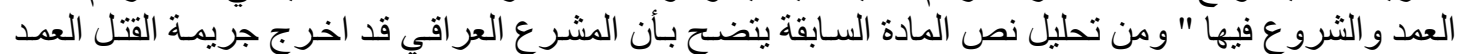

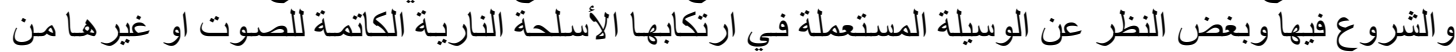

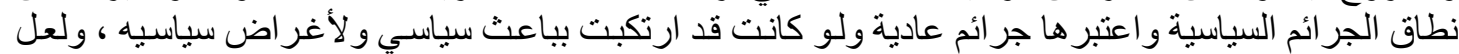

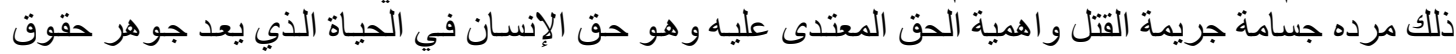

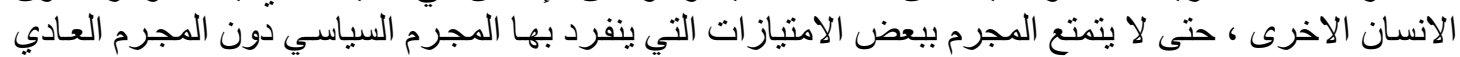

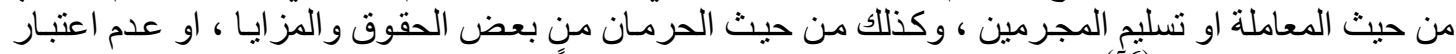

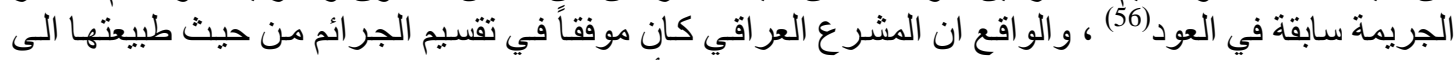

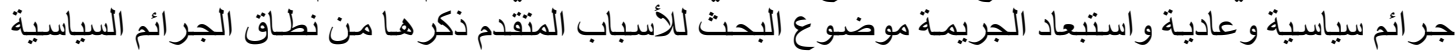

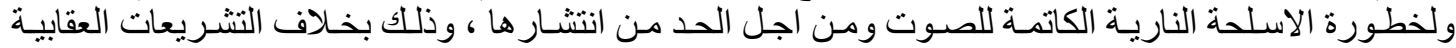

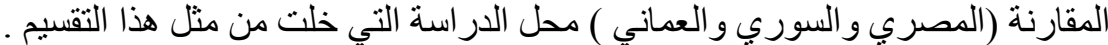

$$
\text { المبحث الثناني }
$$

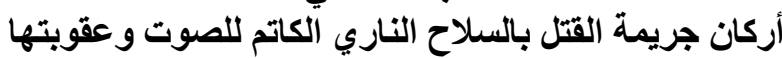

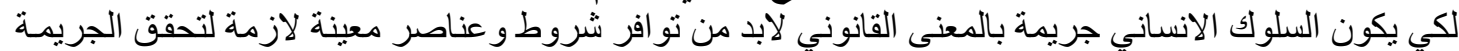

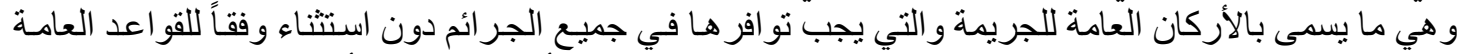

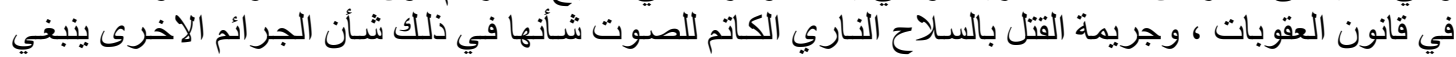

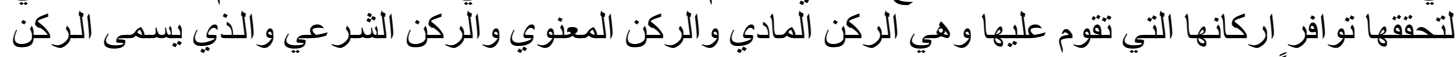

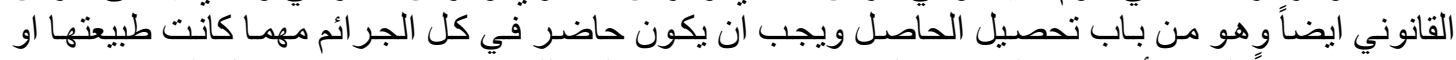

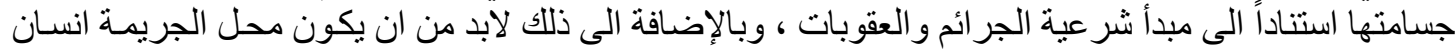

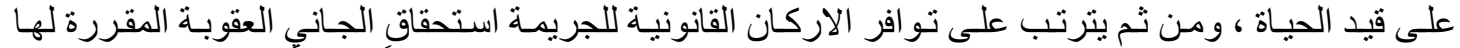

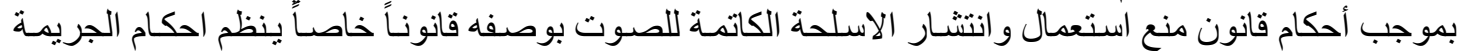

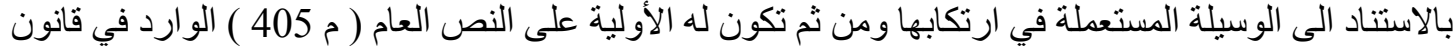

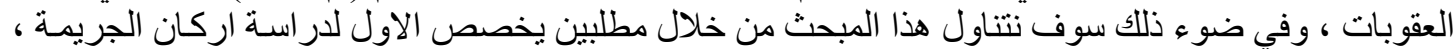

$$
\begin{aligned}
& \text { فيما يخصص الَّرع الثاني لدراسة عقوبة الجريمة و على النحو الاتي : }
\end{aligned}
$$

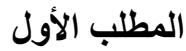

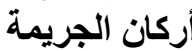

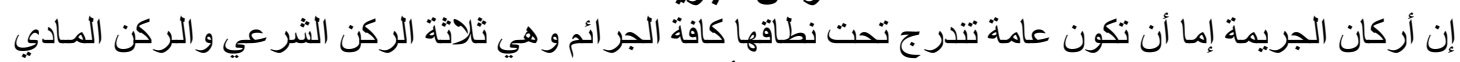

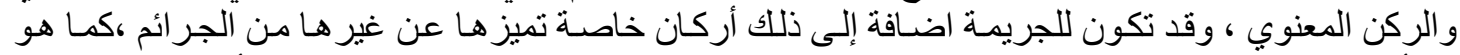

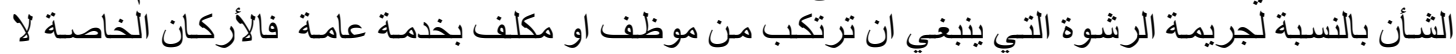

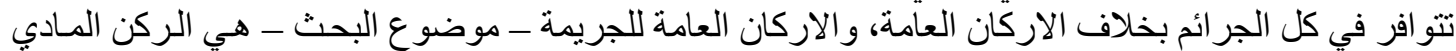

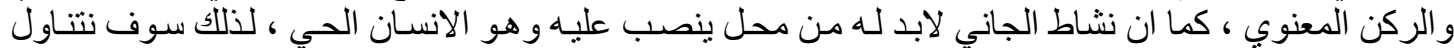

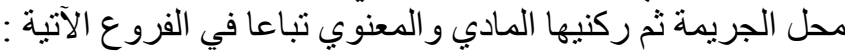

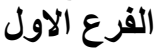

محل الجريمة (ان يكون الأنساناً حياً)

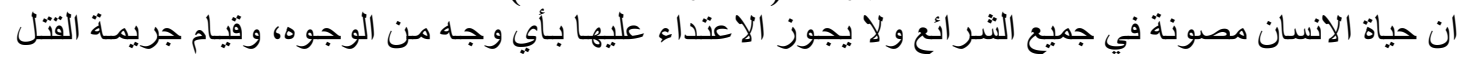

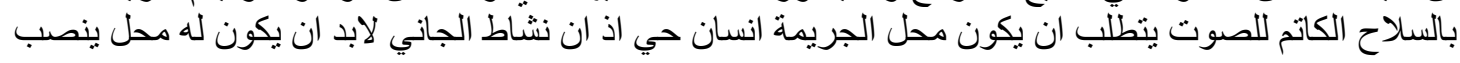




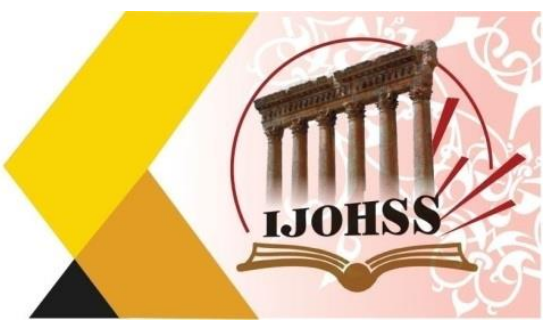

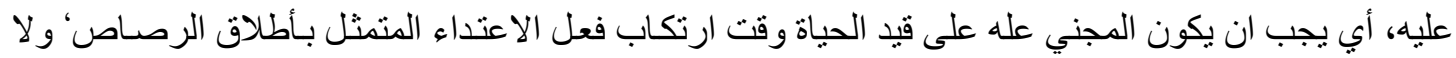

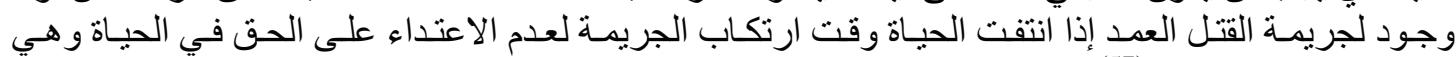

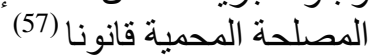

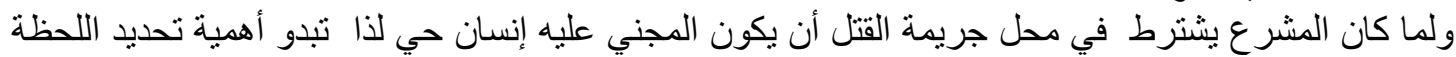

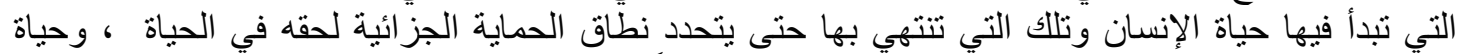

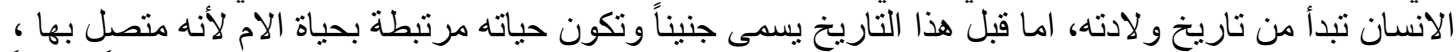

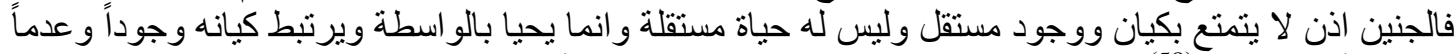

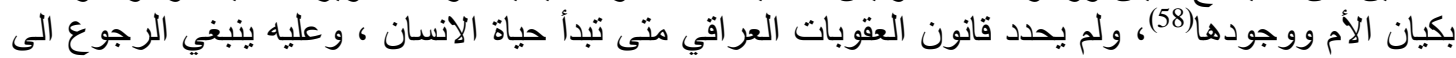

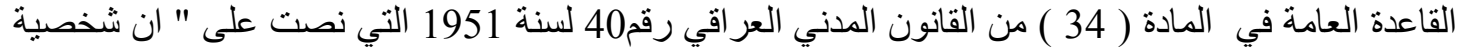

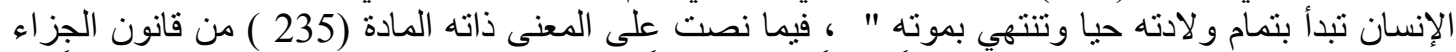

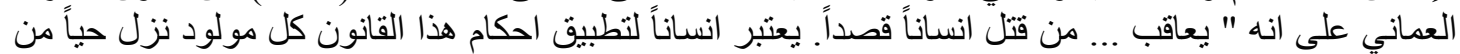

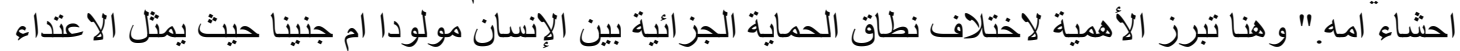

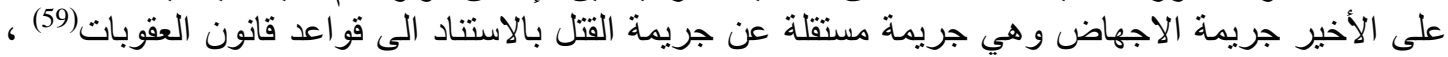

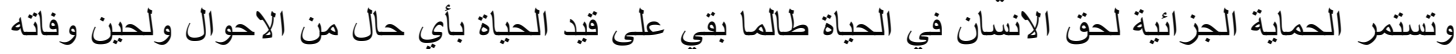

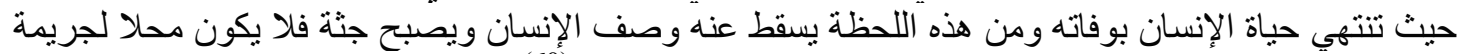

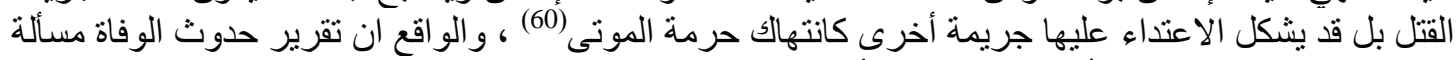

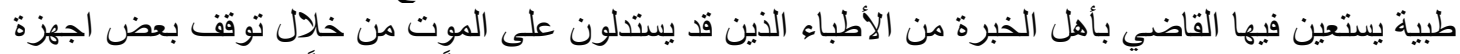

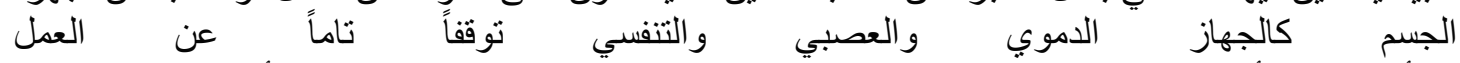
الا أن توقف الأجزةة الحيوية عن العمل لا يؤدي بالضرورة إلى الى حدوث الوفاة إذ قد يقرر الأطباء إمكان استعادة

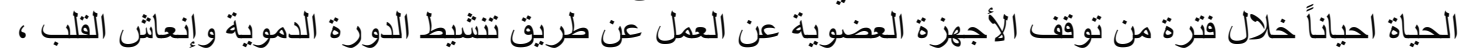

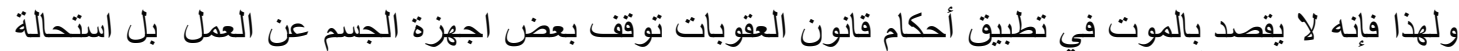

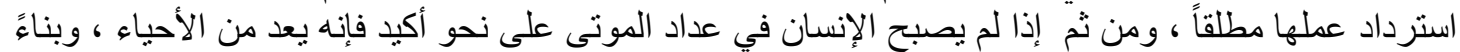

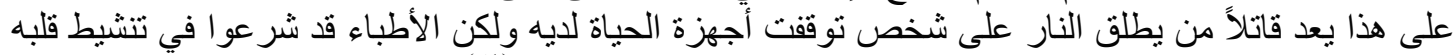

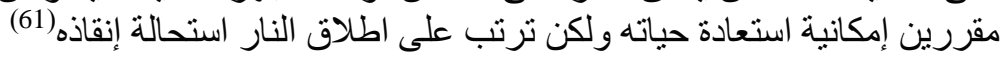

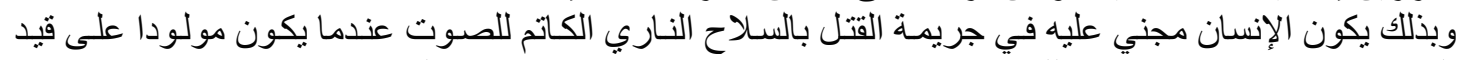

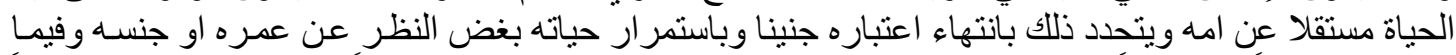

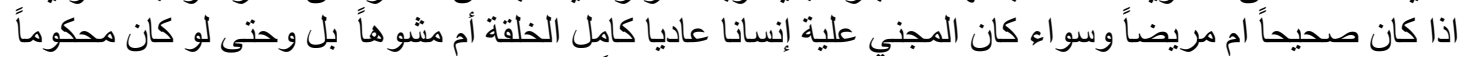

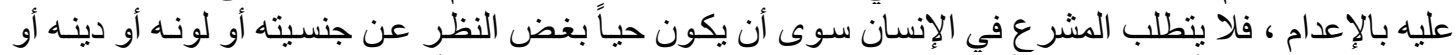

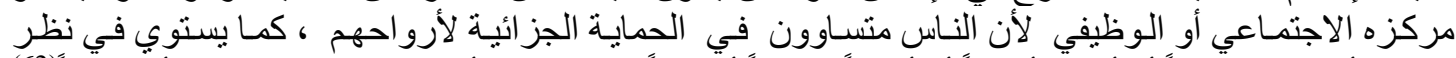

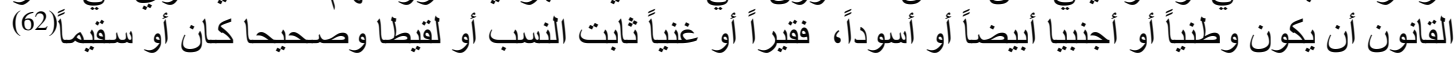

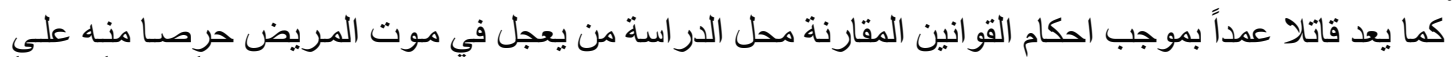

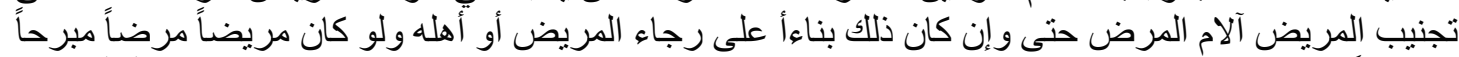

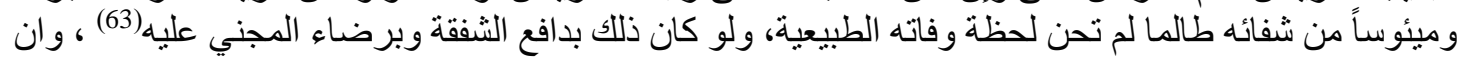

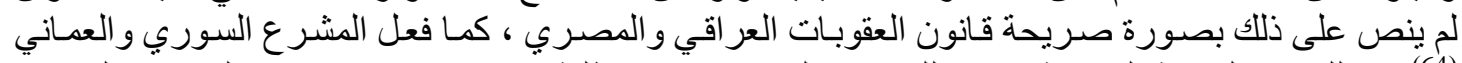

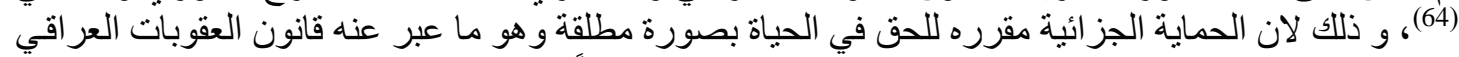

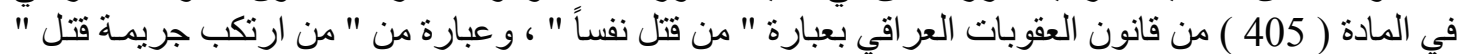

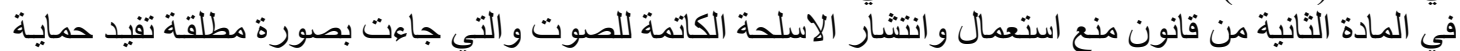

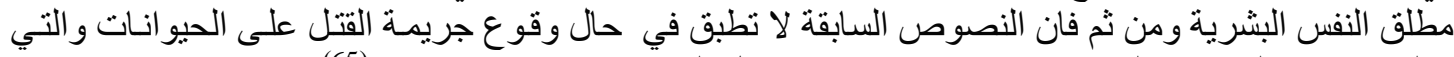

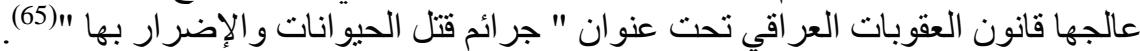




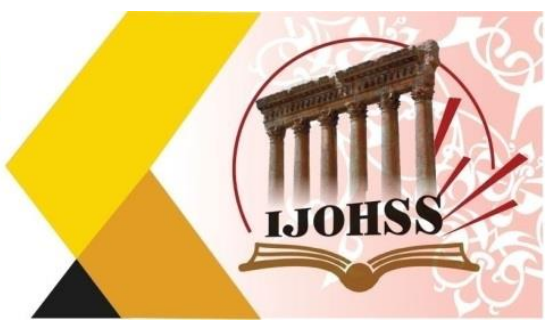

\author{
الفرع الثاني

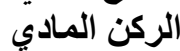

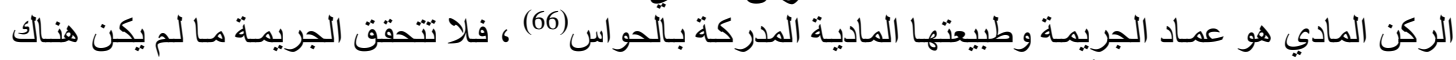

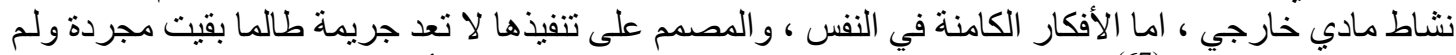

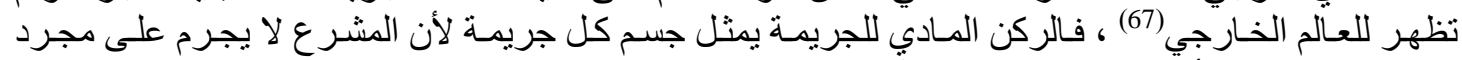

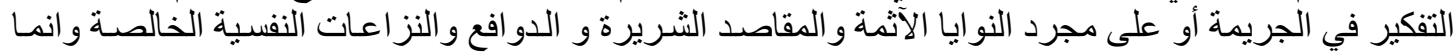

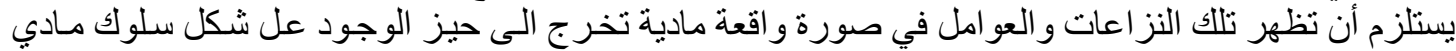

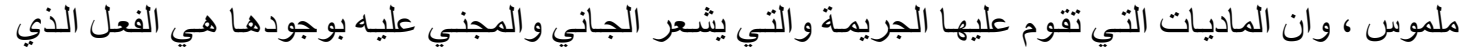

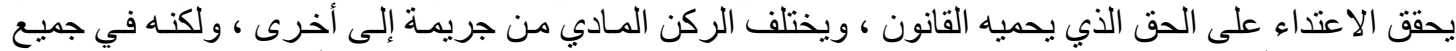

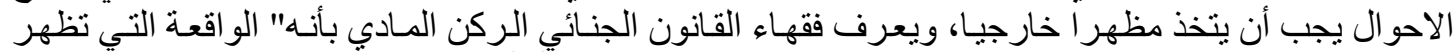

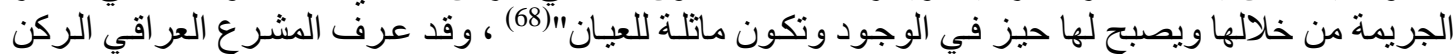

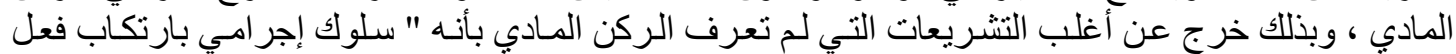

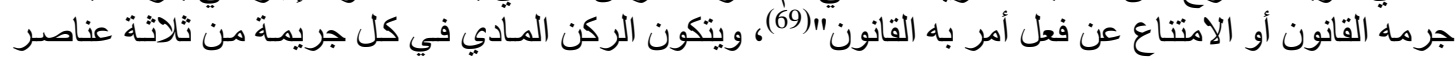

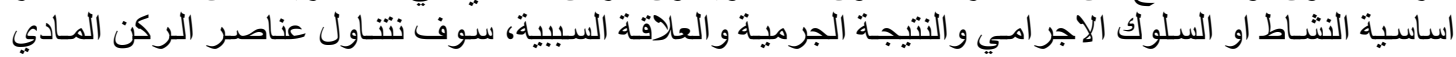

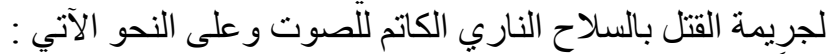

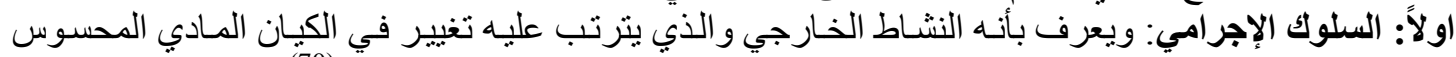

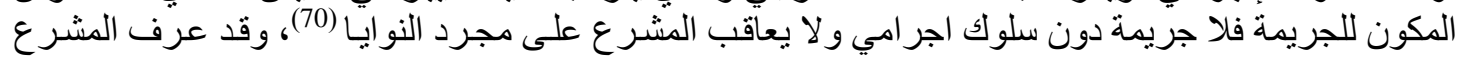

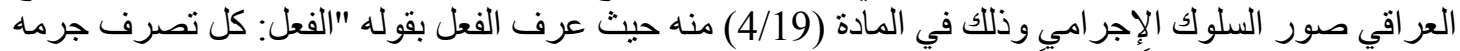

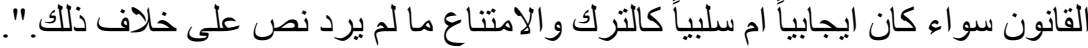

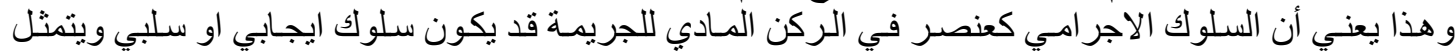

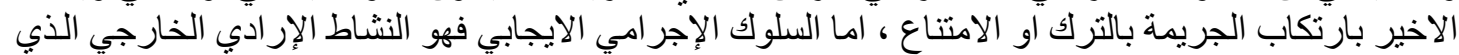

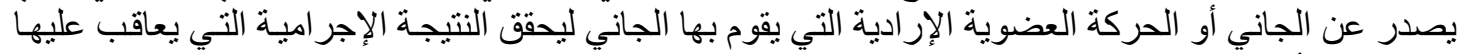

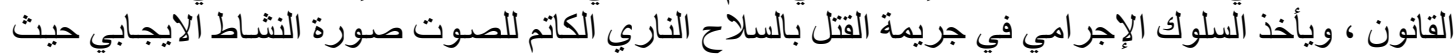

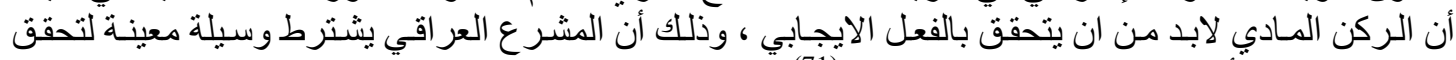

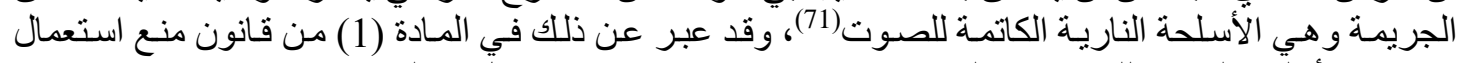

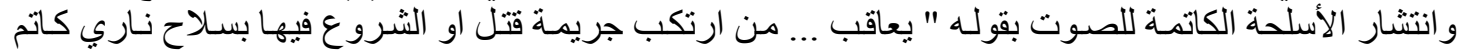

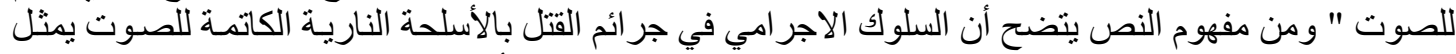

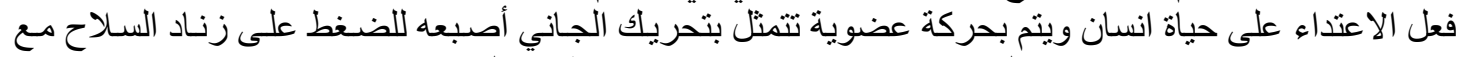

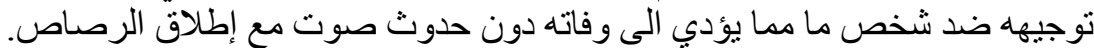

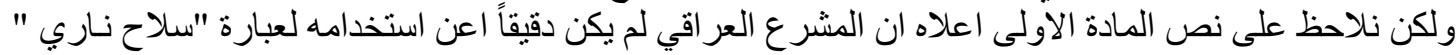

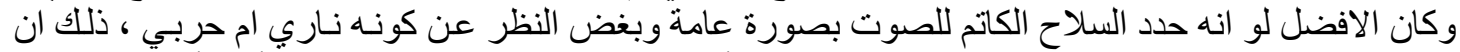

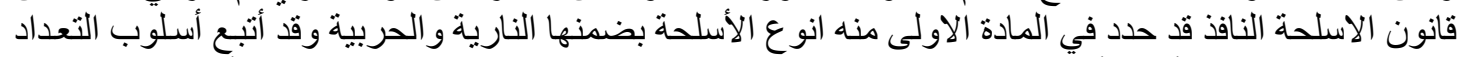

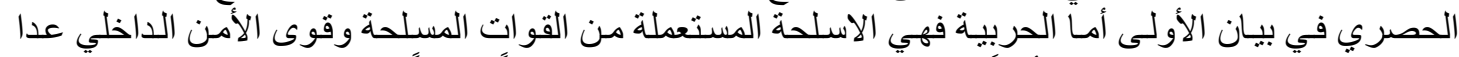

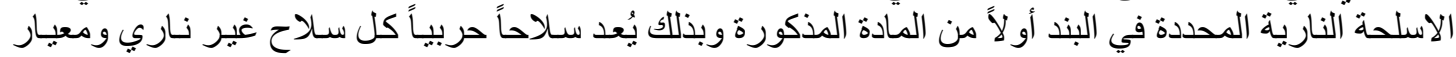

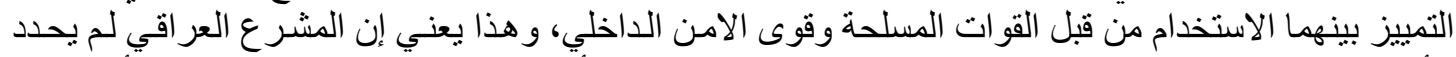

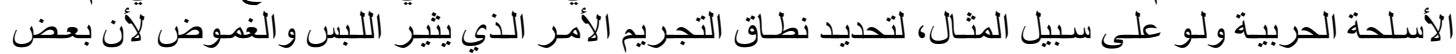

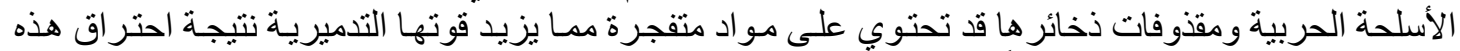

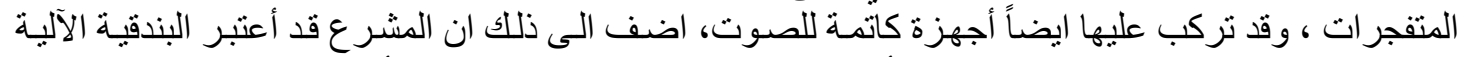

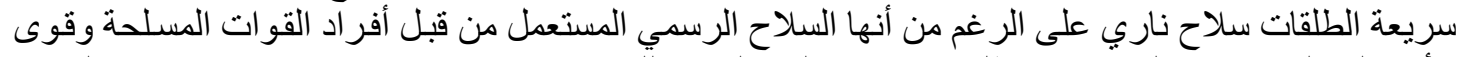

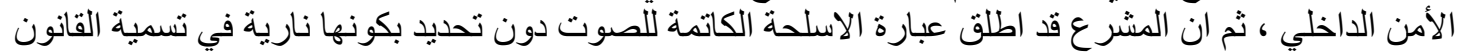

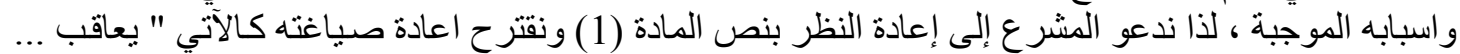

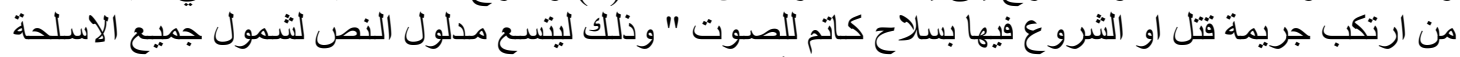

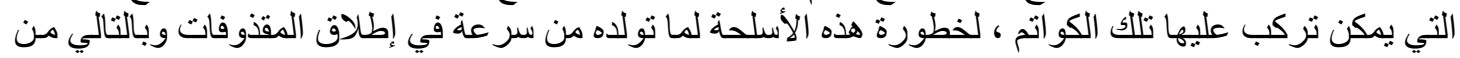




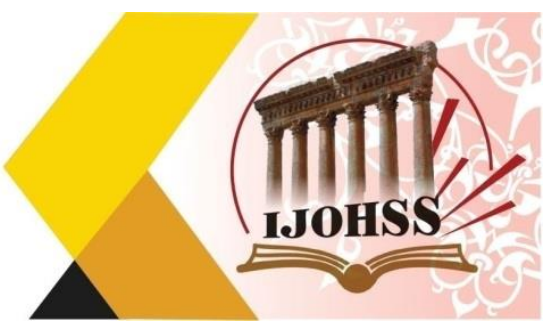

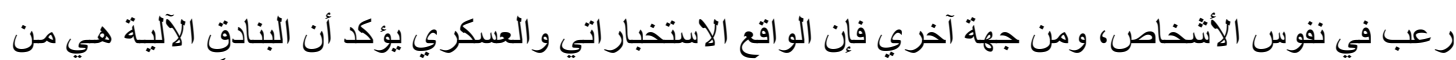

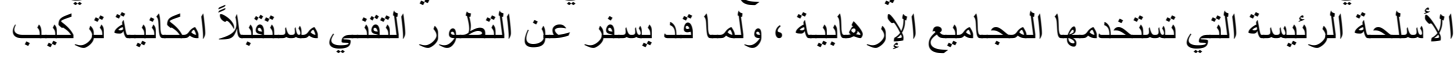

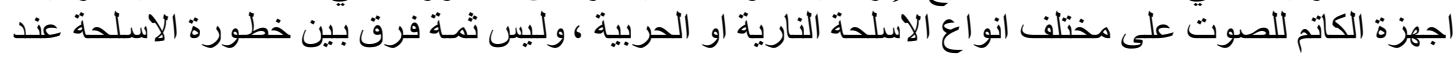

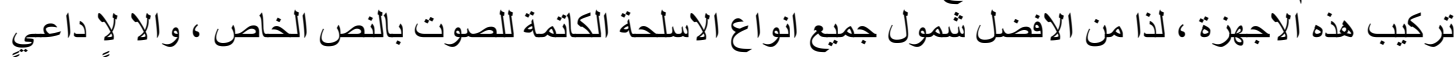

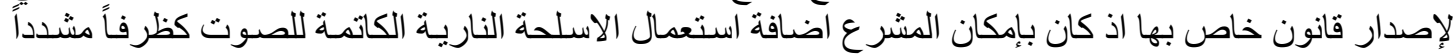

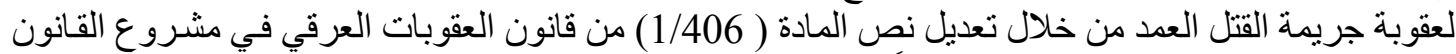

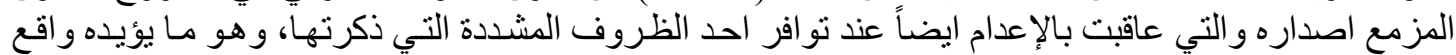

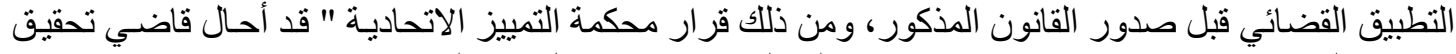

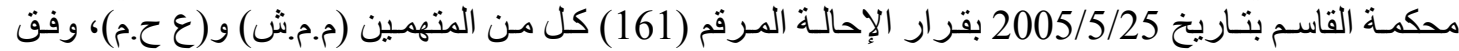

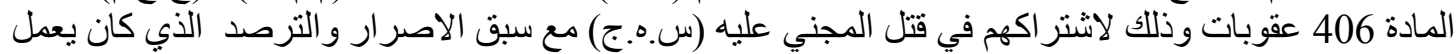

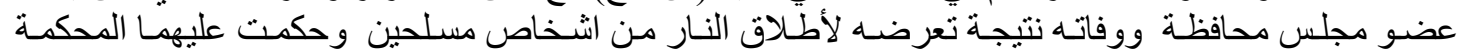

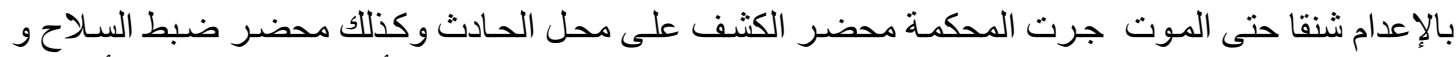

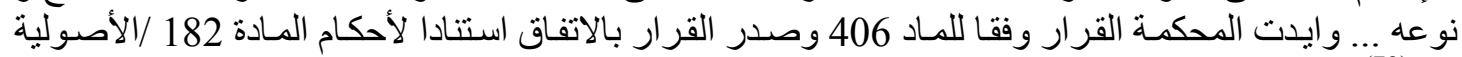
(72)"

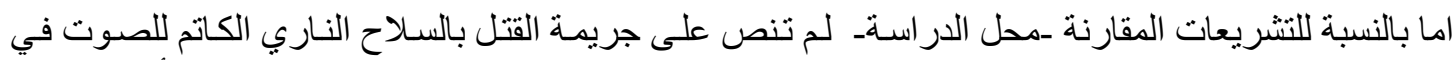

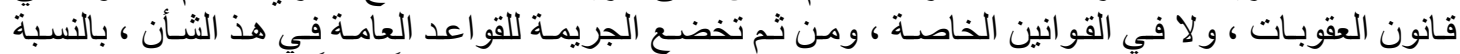

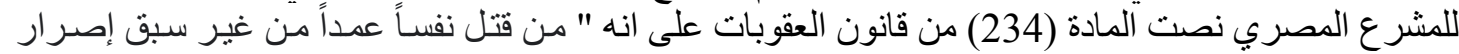

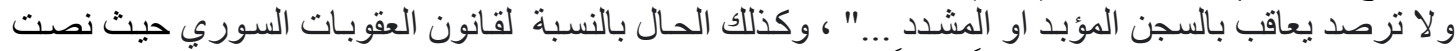

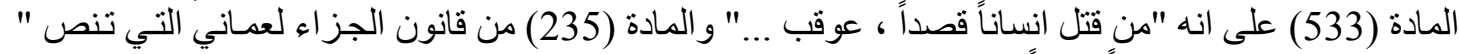

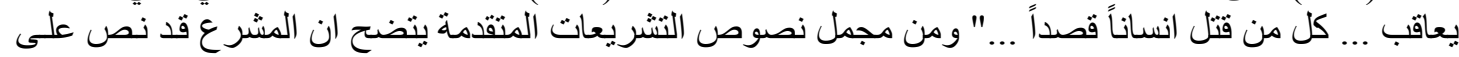

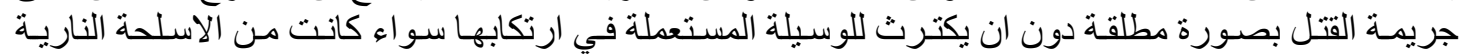

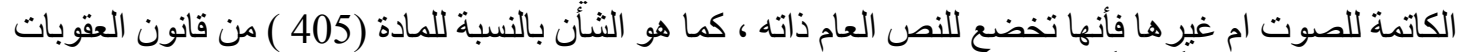

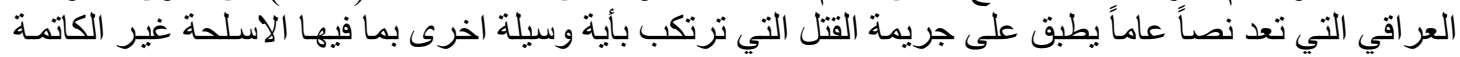

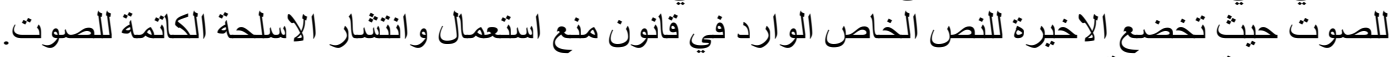

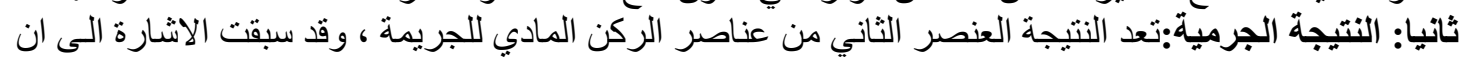

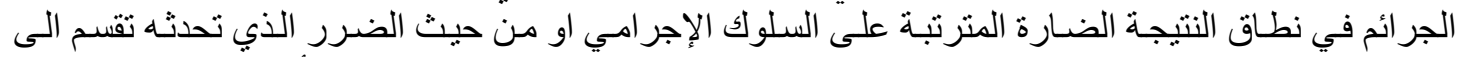

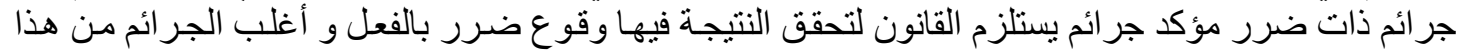

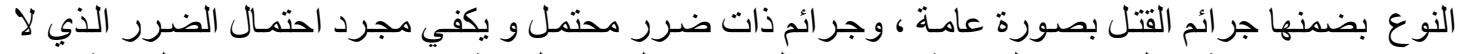

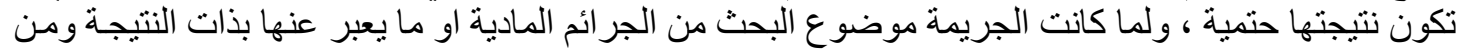

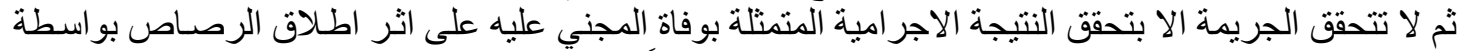

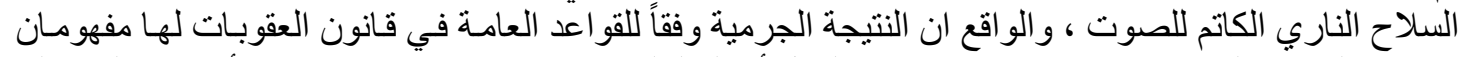

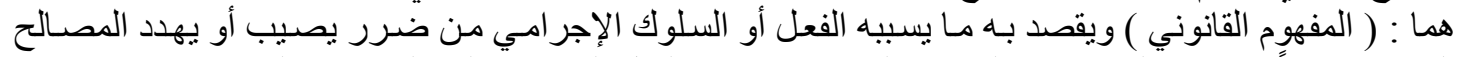

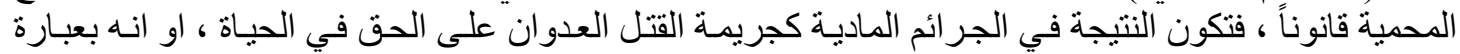

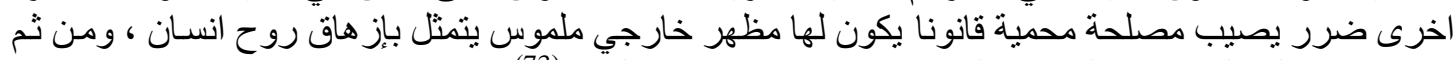

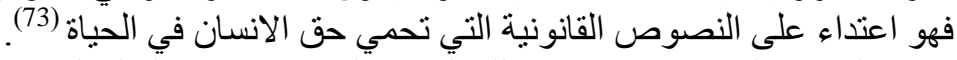

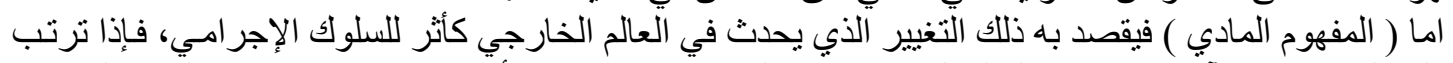

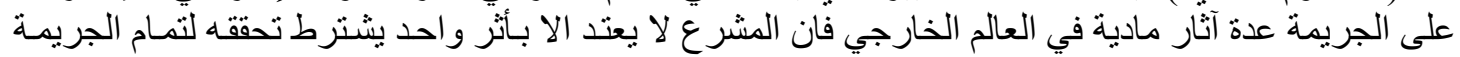

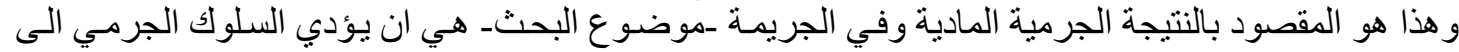

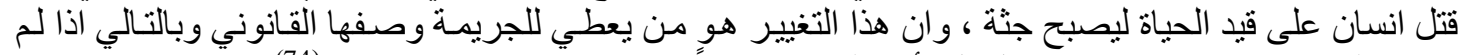

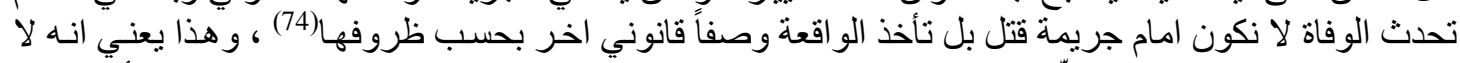

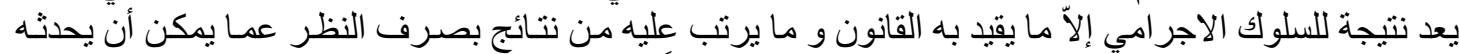

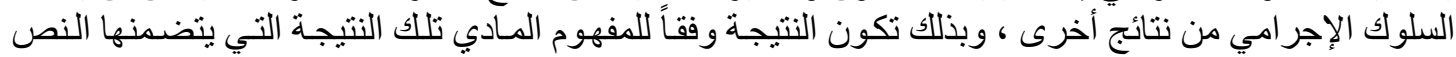




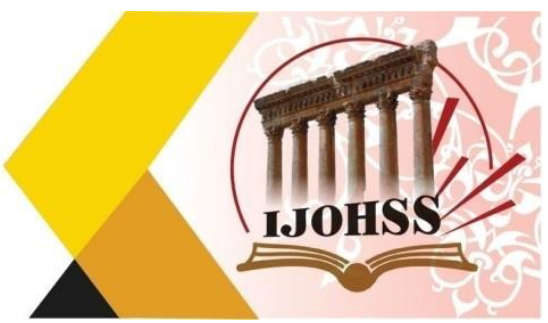

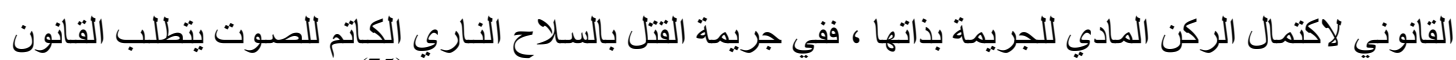

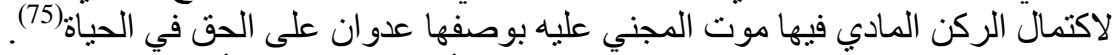

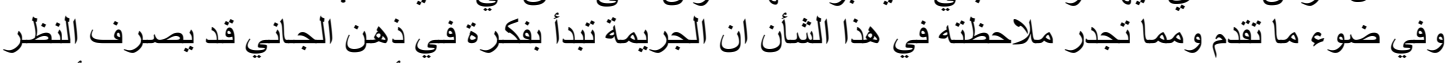

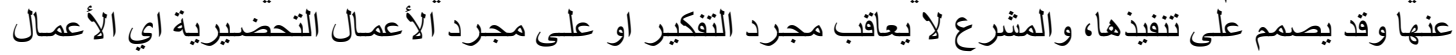

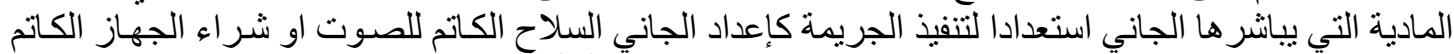

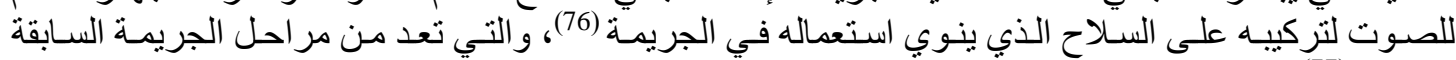

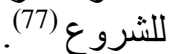

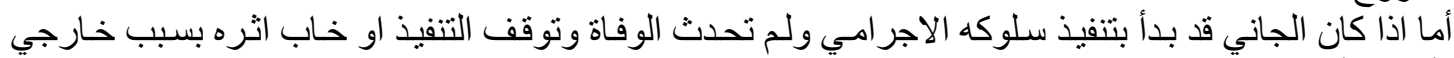

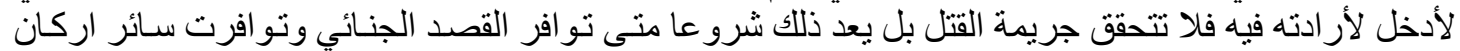

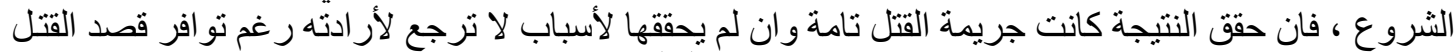

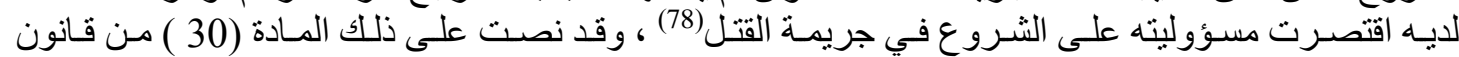

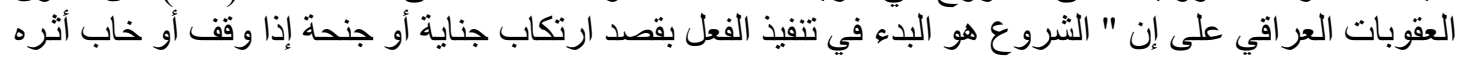

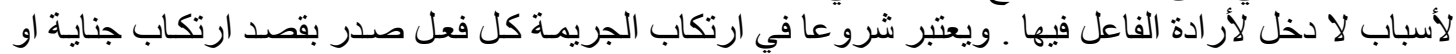

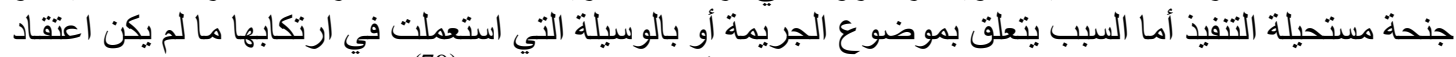

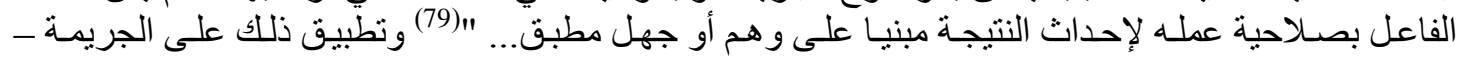

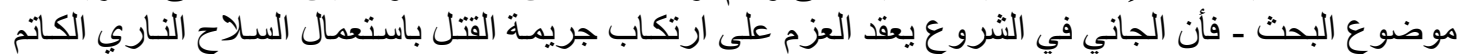

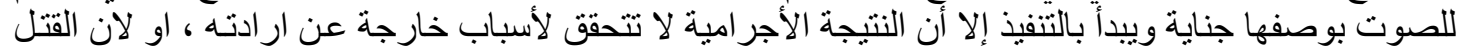

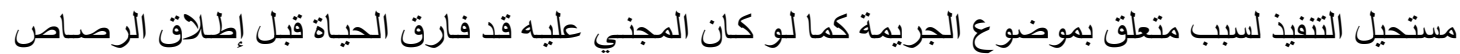

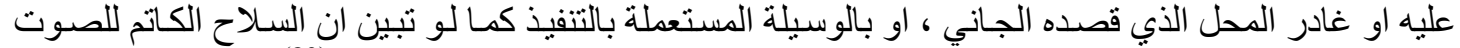

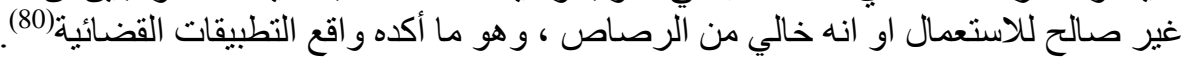

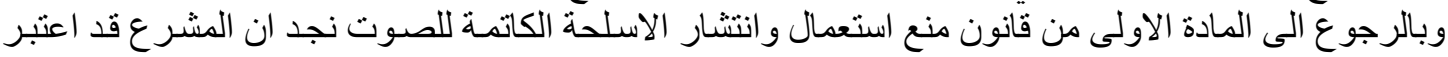

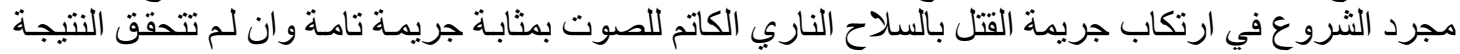

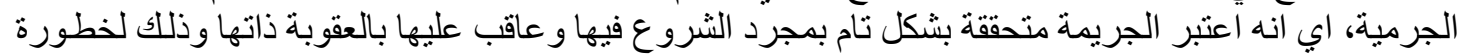

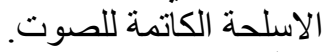

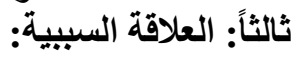

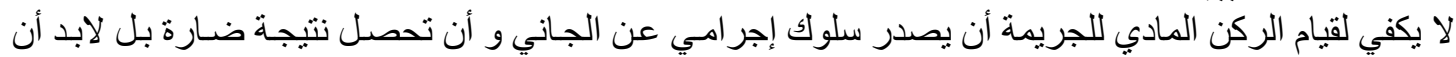

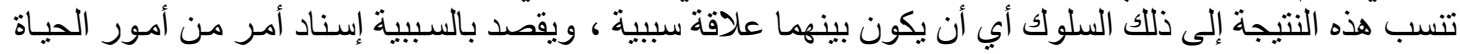

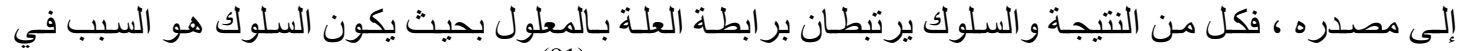

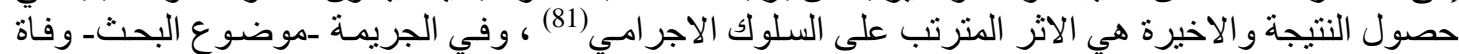

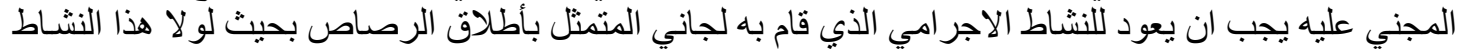

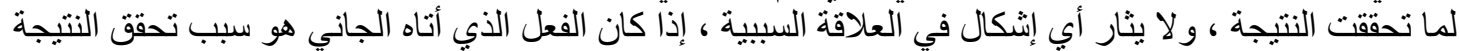

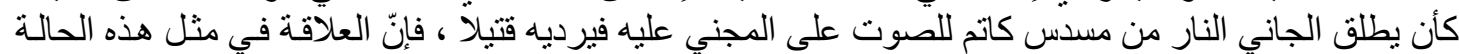

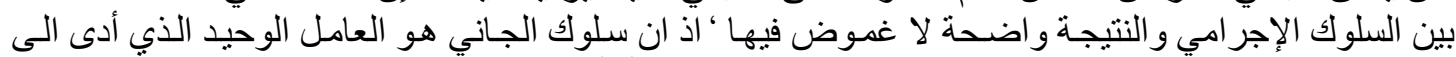

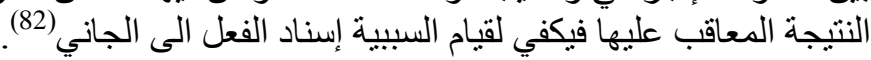

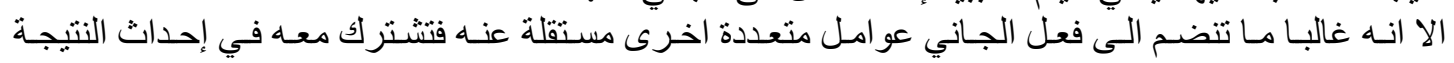

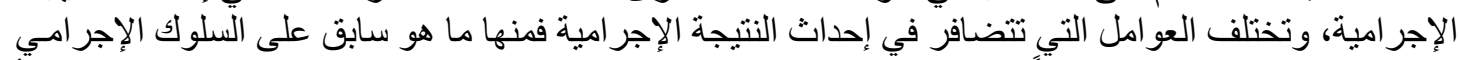

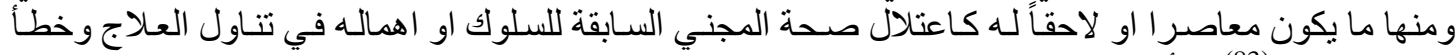

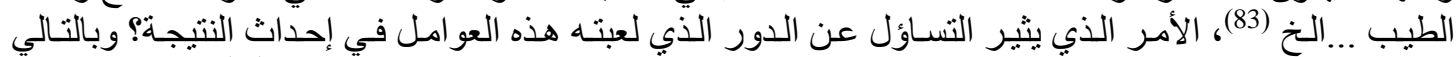

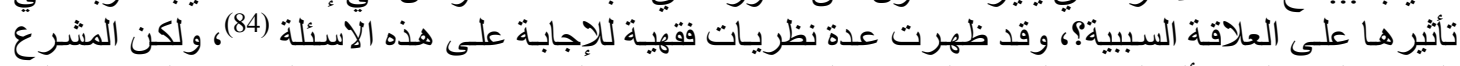

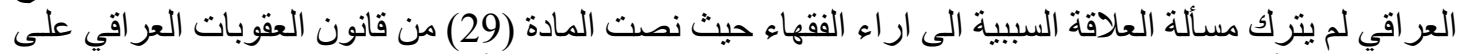

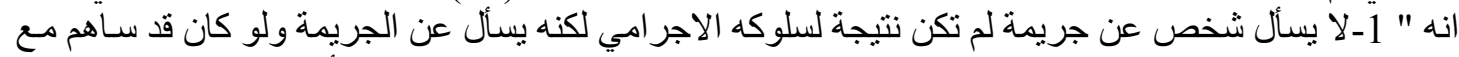

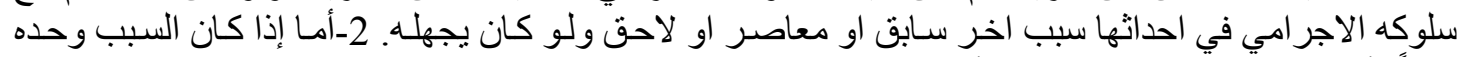

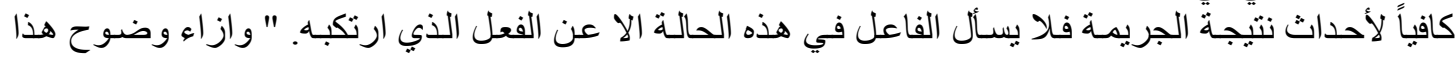




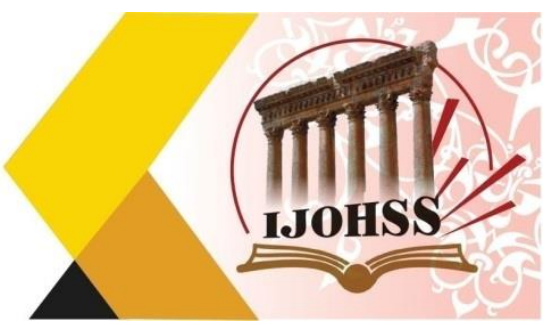

النص ومن خلال تطبيقه على الجريمة موضوع البحث يتبين ان المشرع العر اقي اخذ بنظريـة تعادل الاسباب

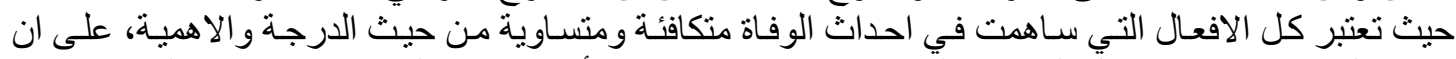

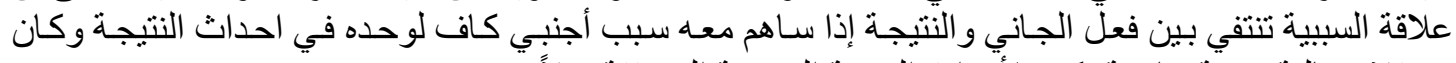

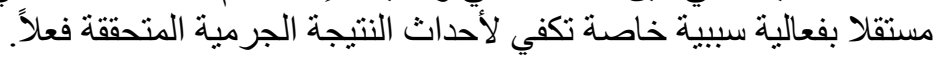

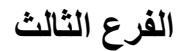

الركن المعنوي

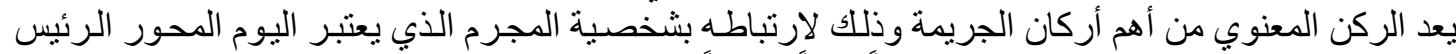

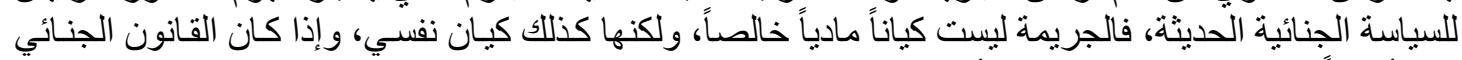

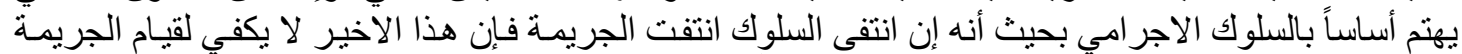

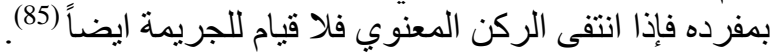

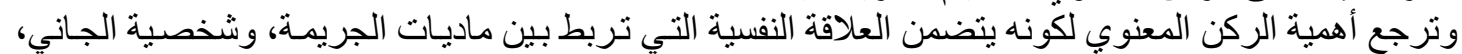

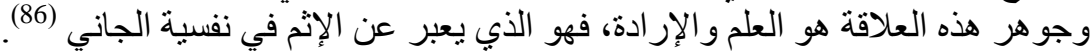

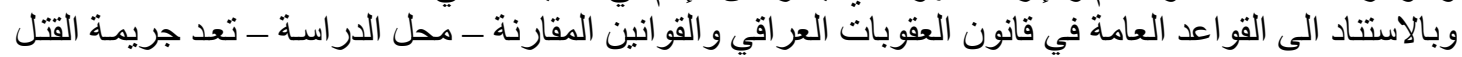

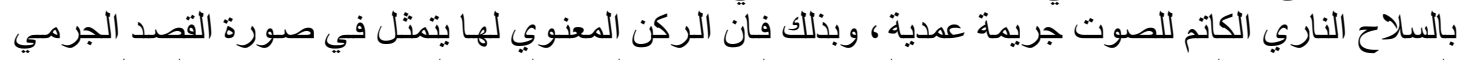

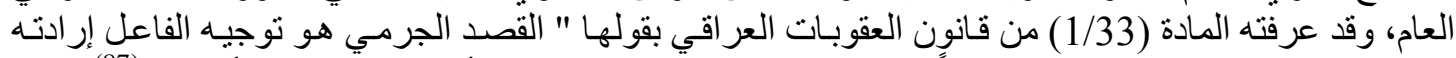

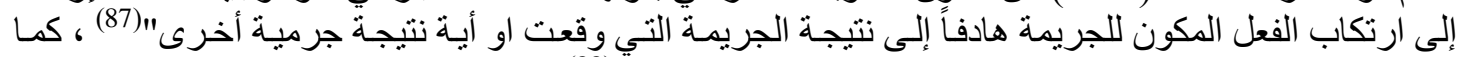

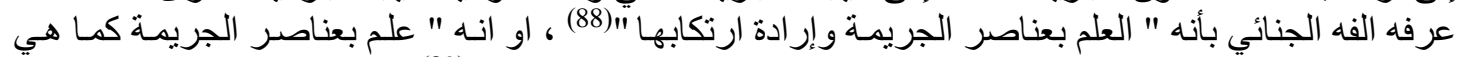

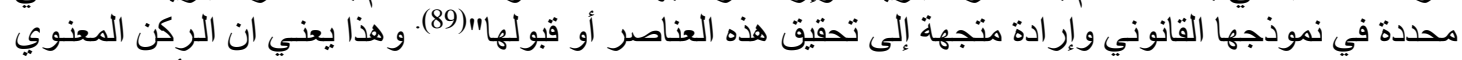

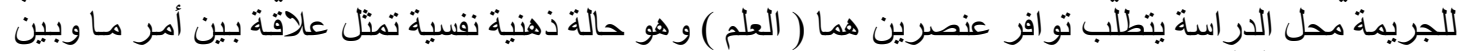

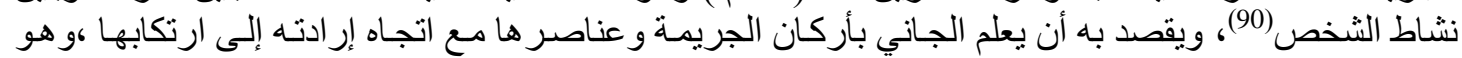

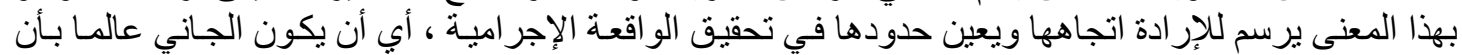

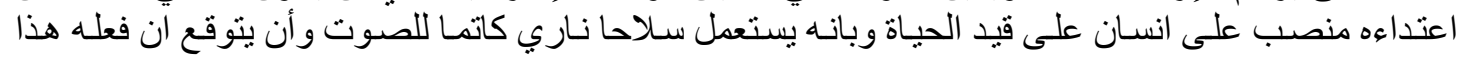

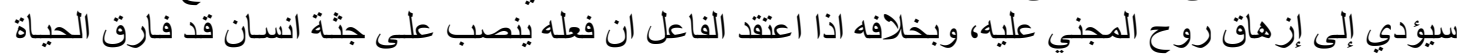

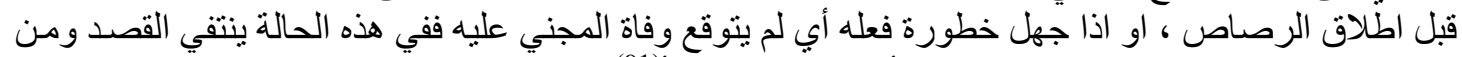

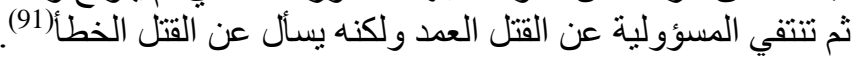

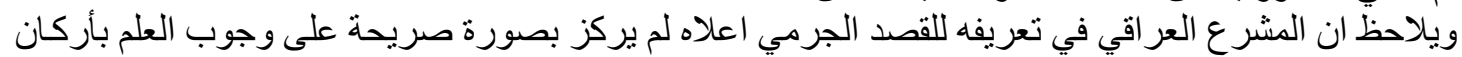

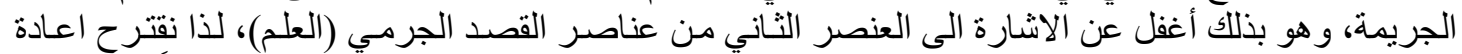

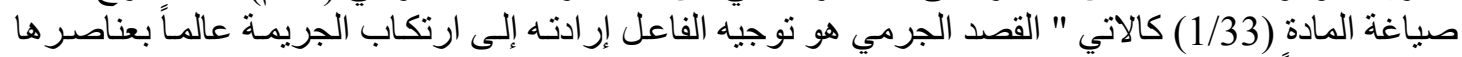

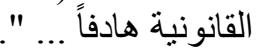

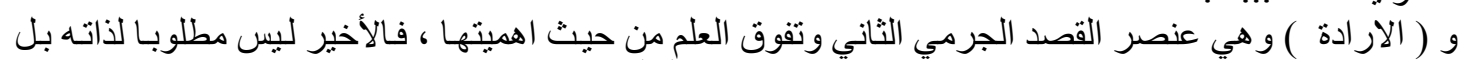

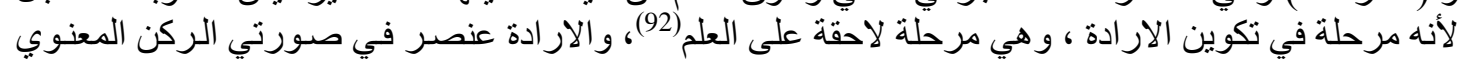

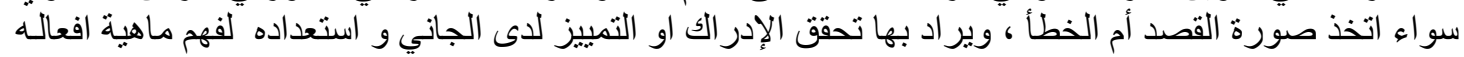

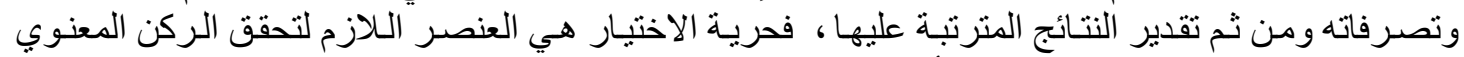

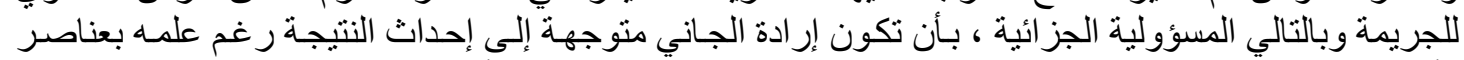

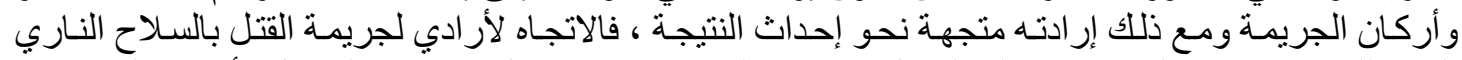

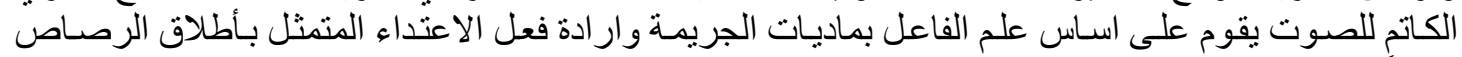

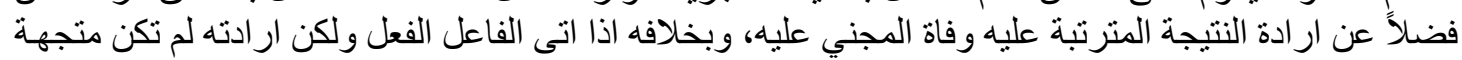

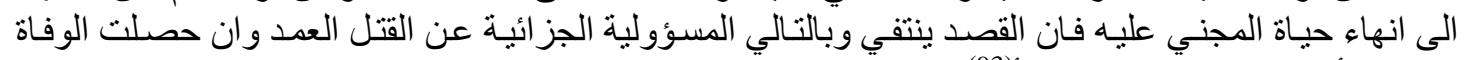

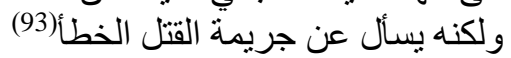

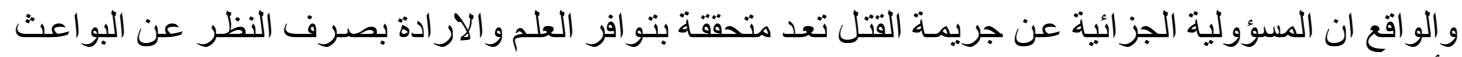

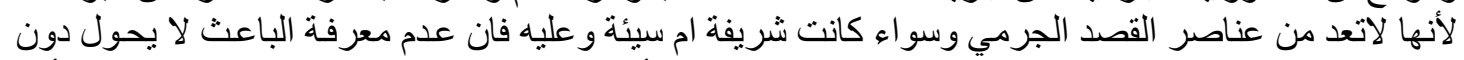

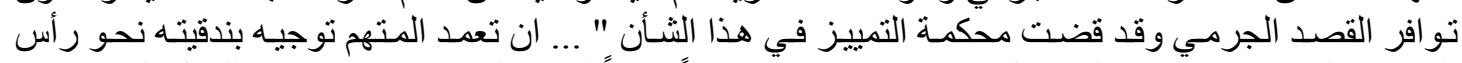

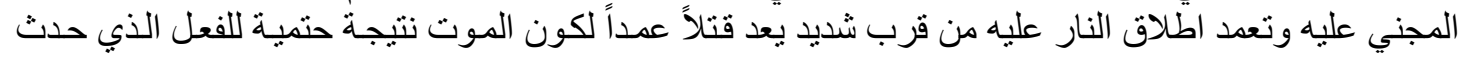




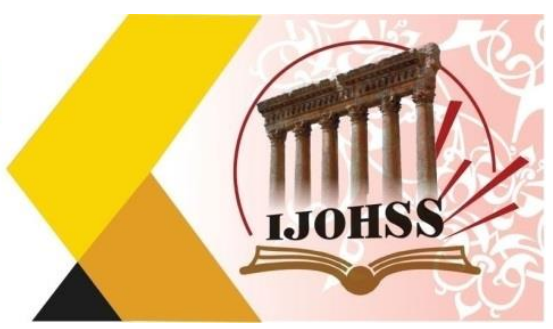

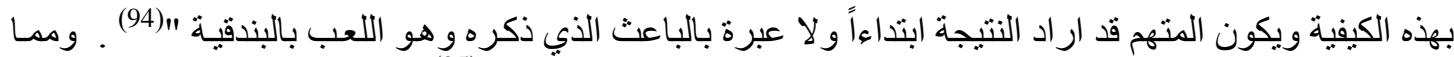

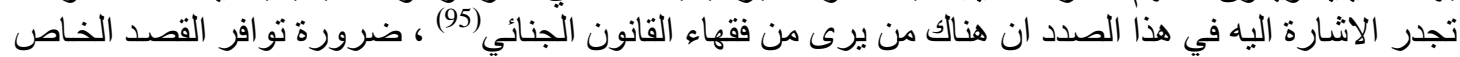

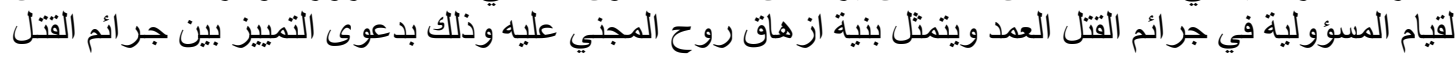

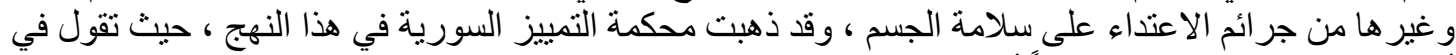

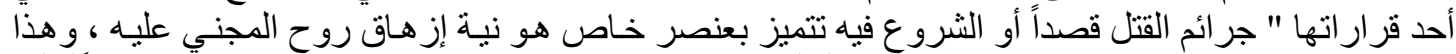

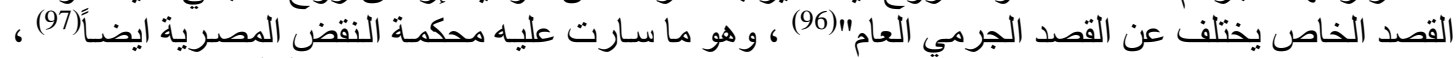

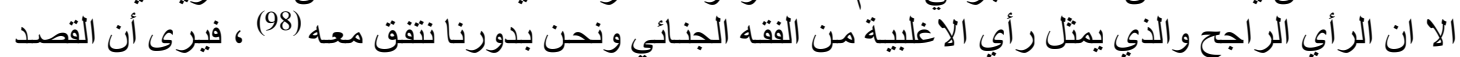

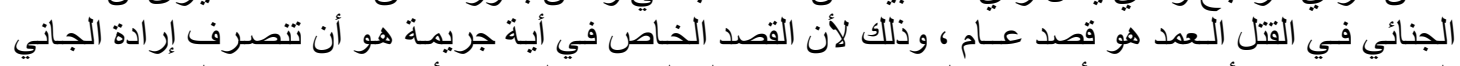

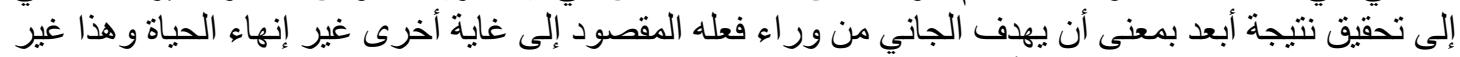

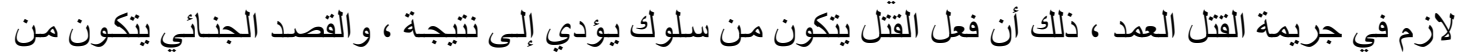

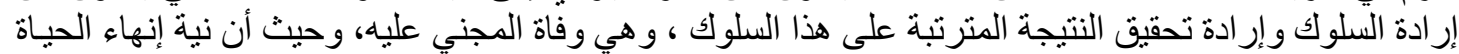

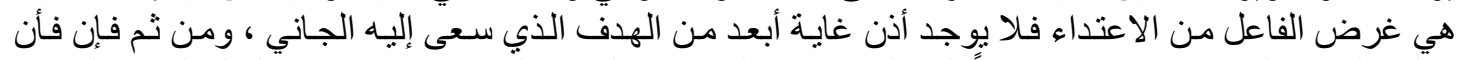

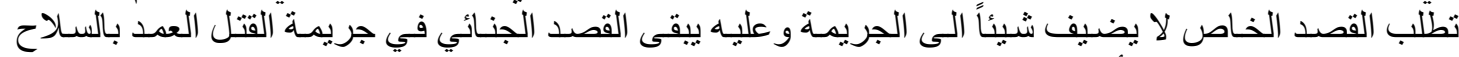

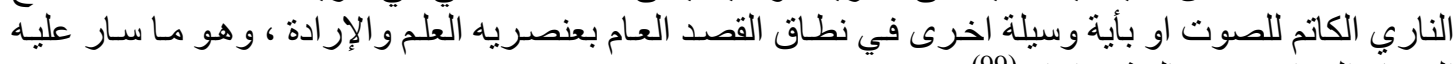

القضاء العر اقي في غالبية قرار اته(99).

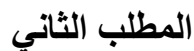

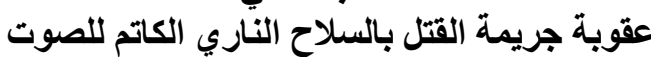

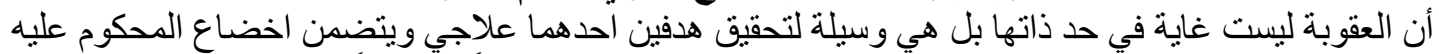

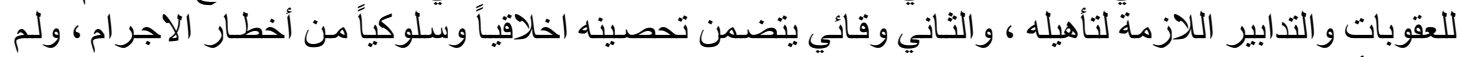

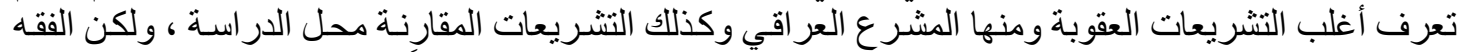

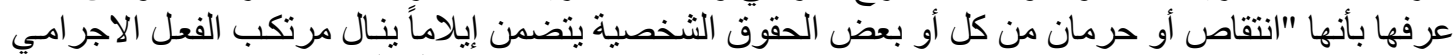

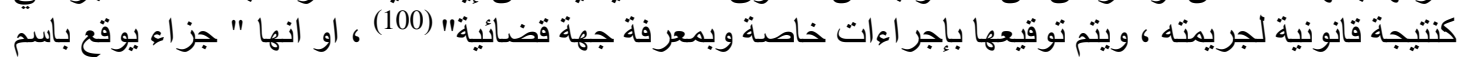

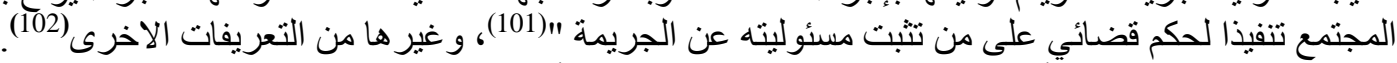

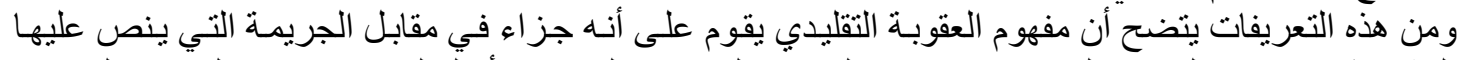

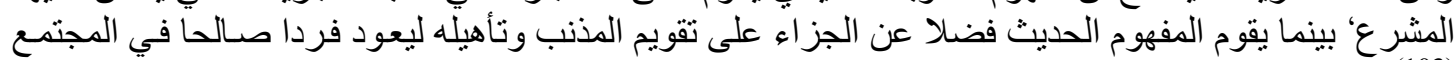

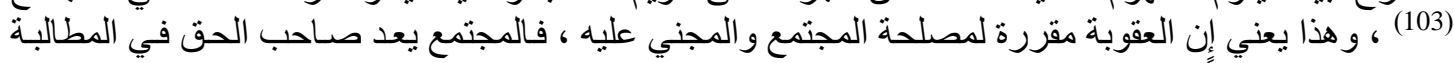

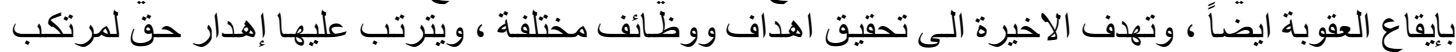

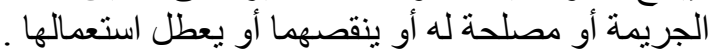

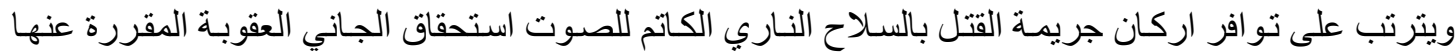

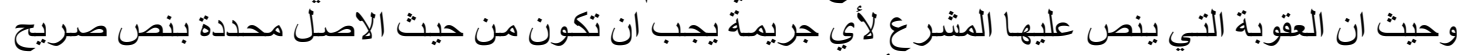

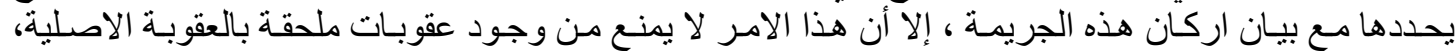

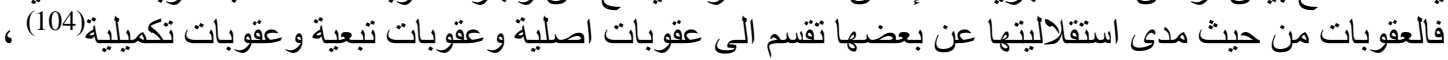

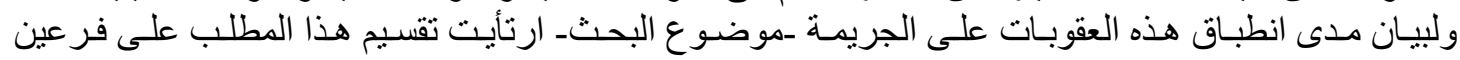

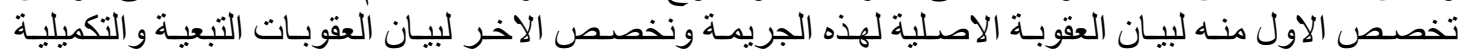

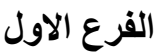 \\ العقوبات الأصلية - الاول}

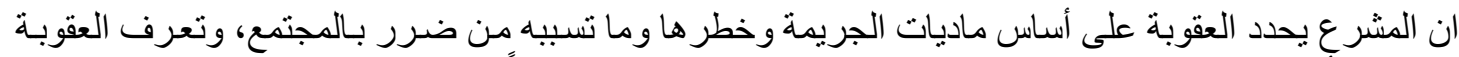

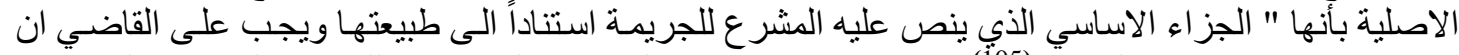

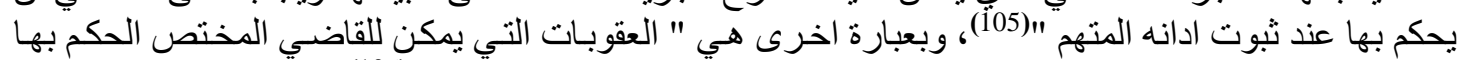

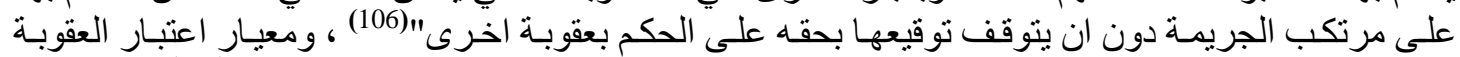

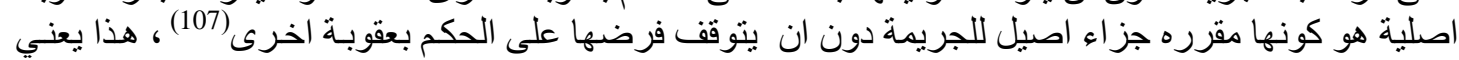

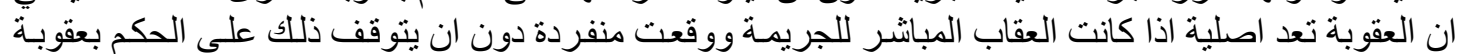




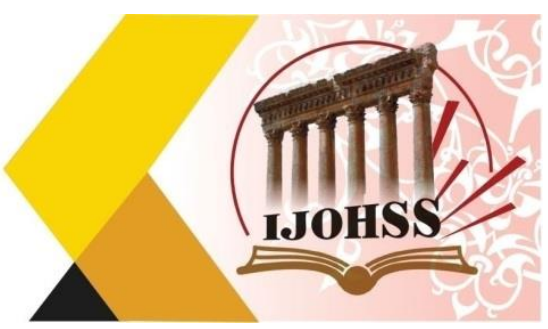

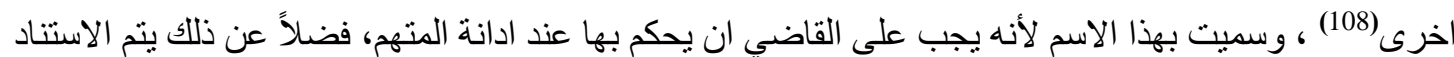

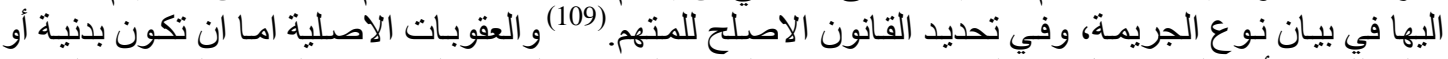

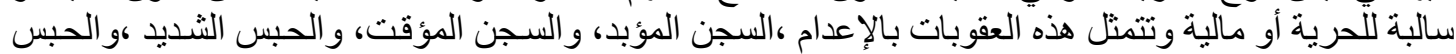

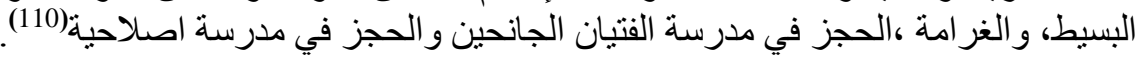

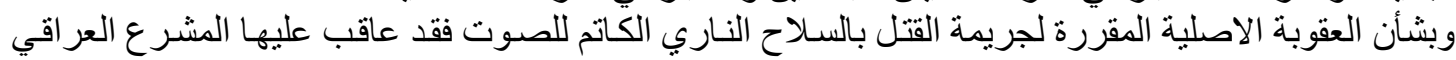

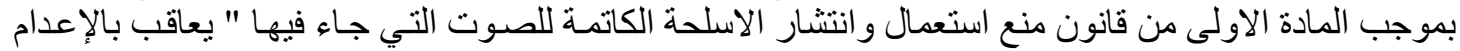

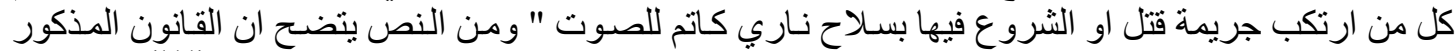

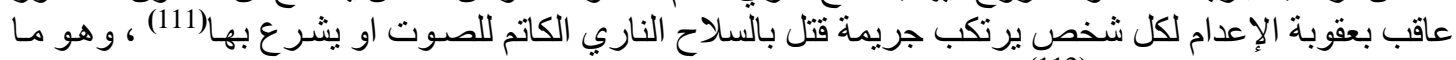
يؤيده و اقع التطبيق القضائي (112)

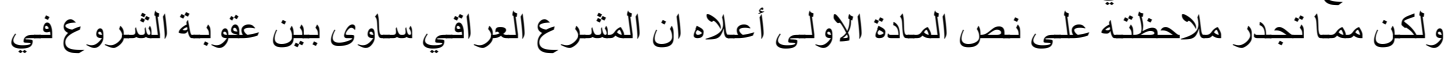

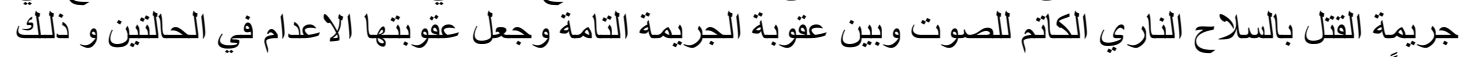

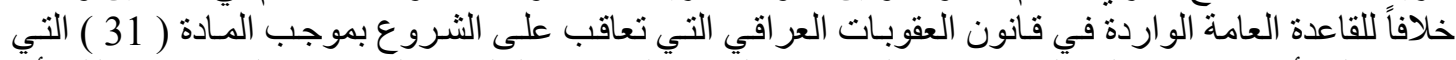

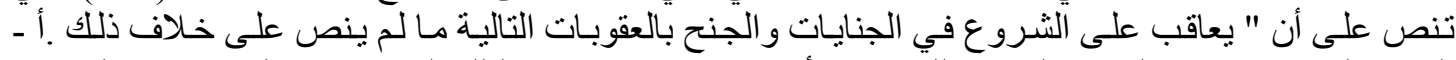

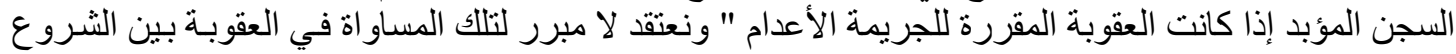

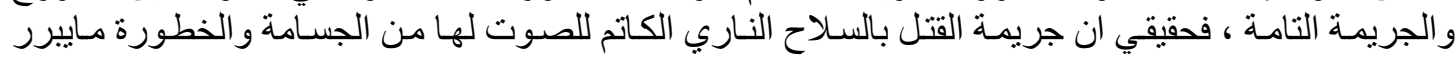

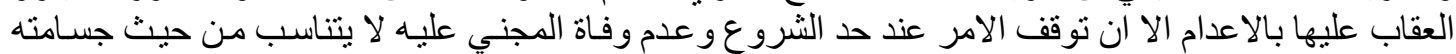

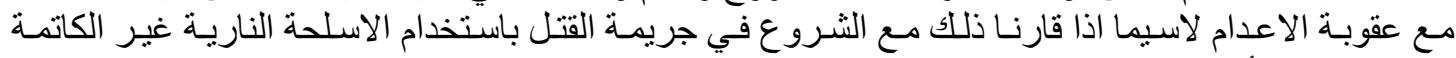

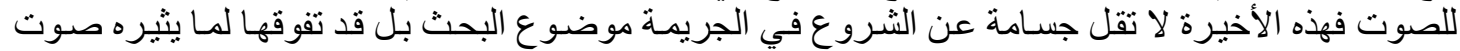

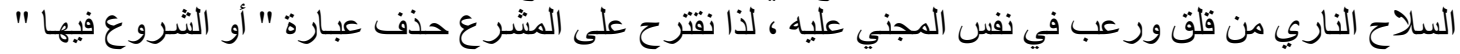

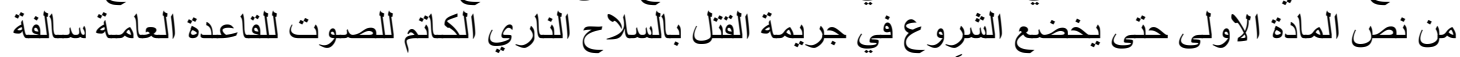

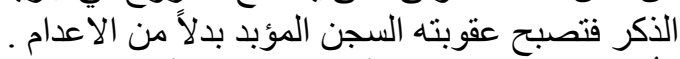

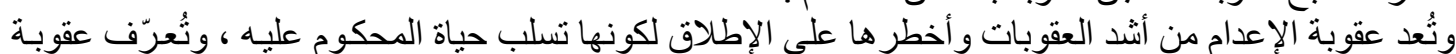

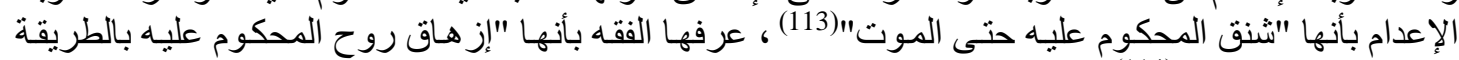

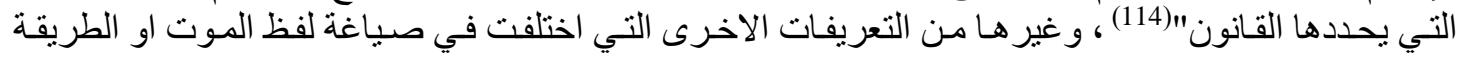

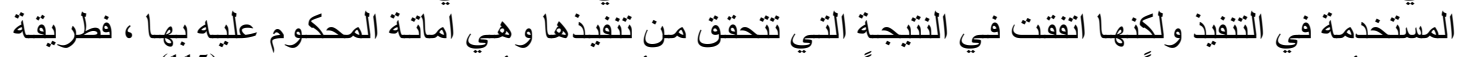

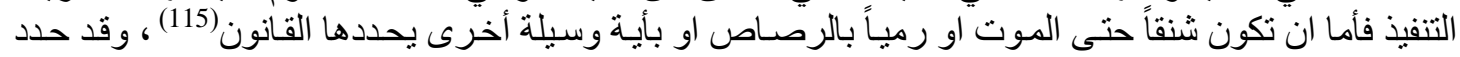

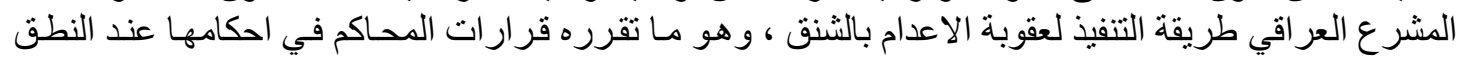

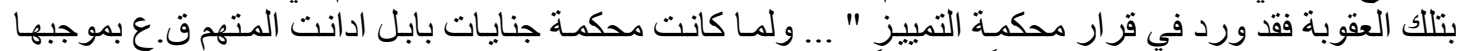

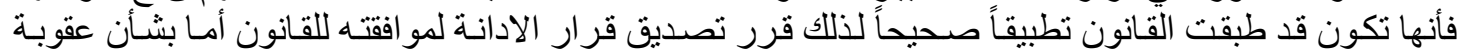

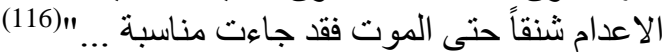

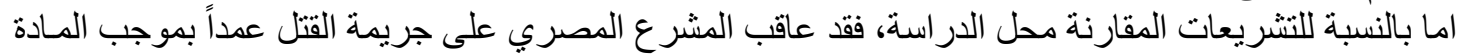

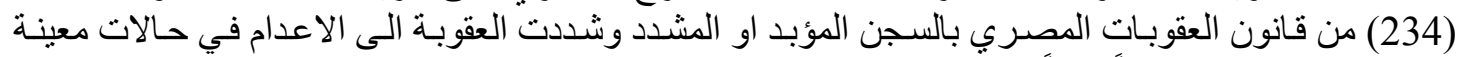

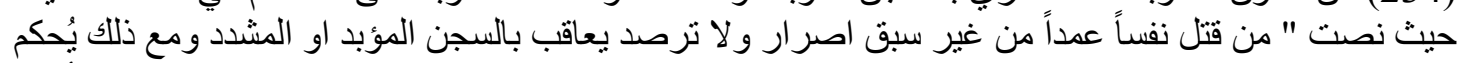

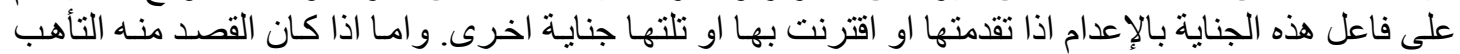

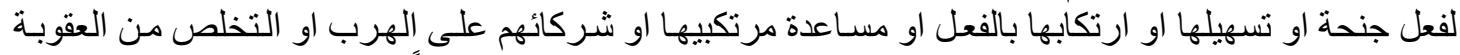

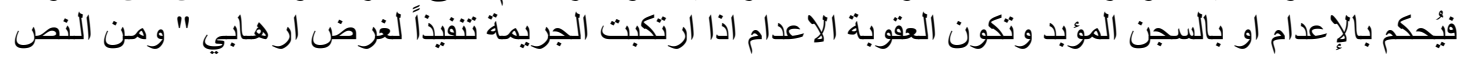

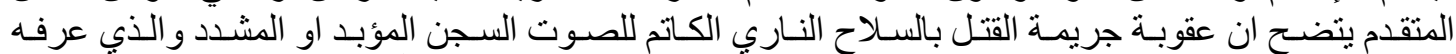

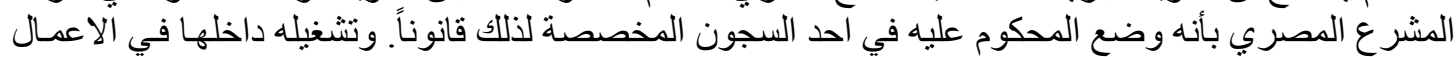

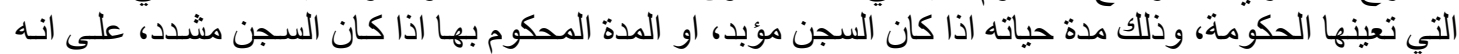

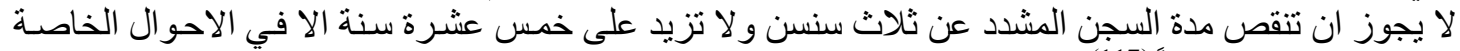

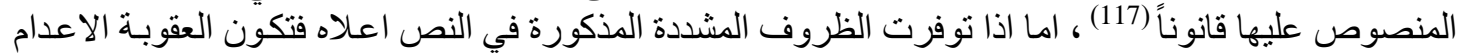

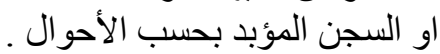




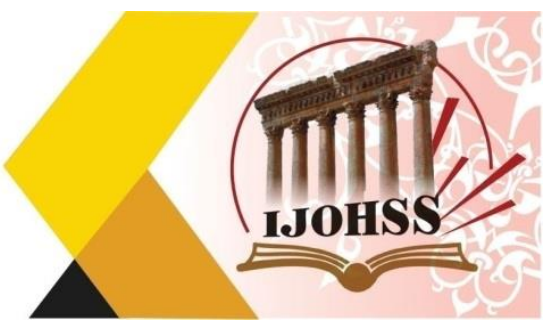

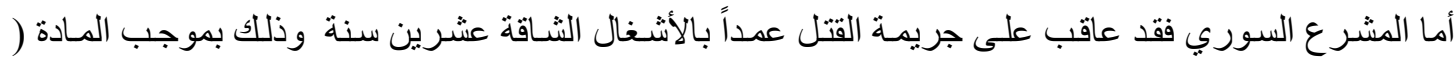

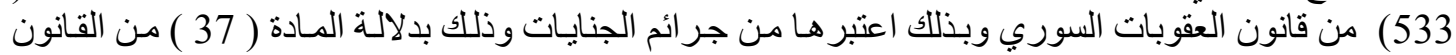

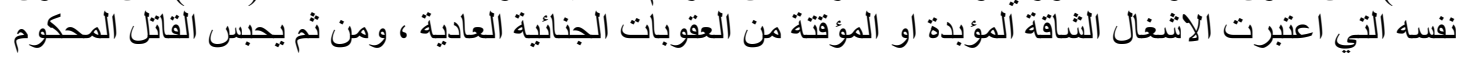

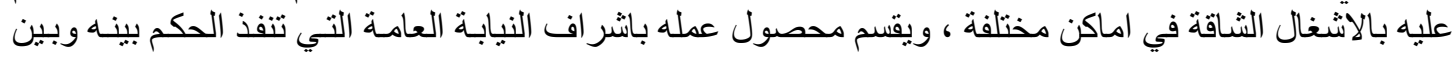

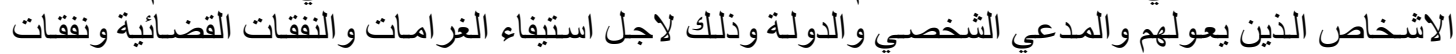

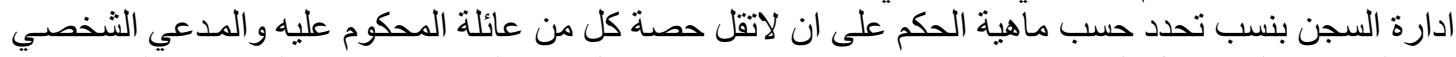

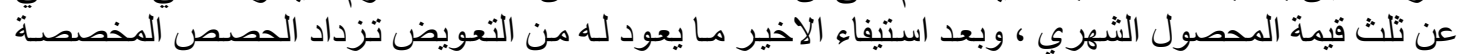

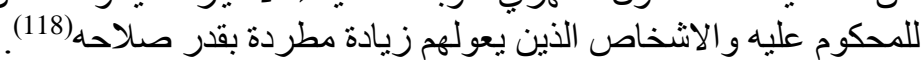

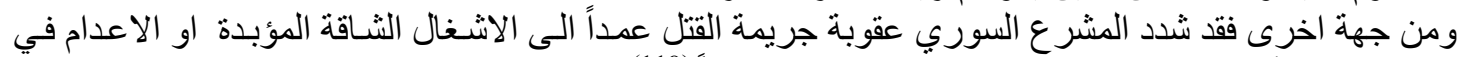

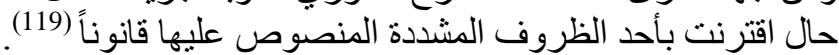

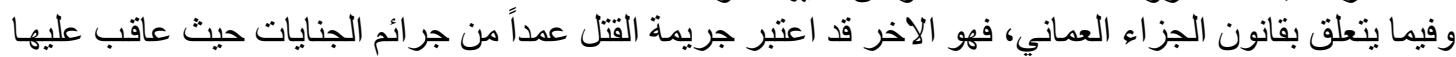

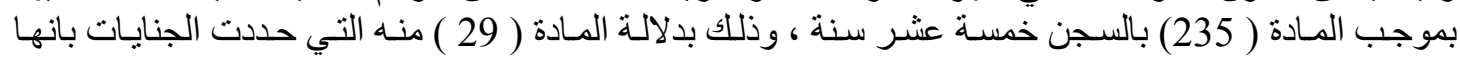

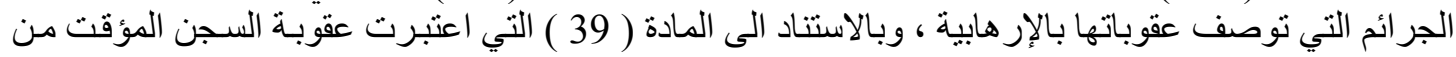

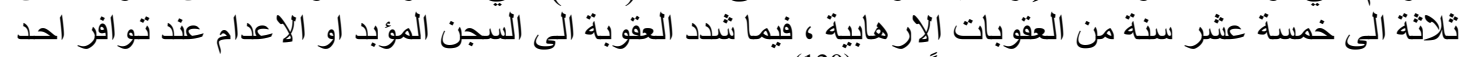

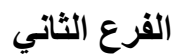 \\ العقوبات التبعية والتكميلية}

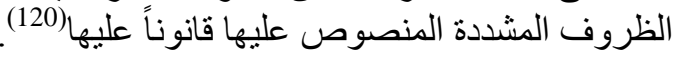

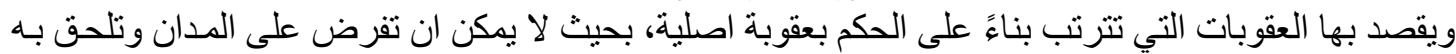
بشكل مستقل، و انما لابد ان يحكم عليه بأحد العقوبات الاصلية التي سبق بيانها وهي اما تابعة للعقوبـة الاصلية أو أو اله مكملة لها (121).

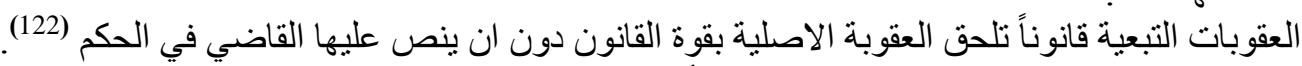

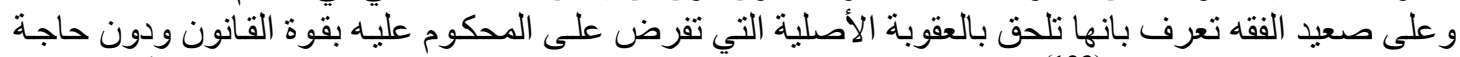

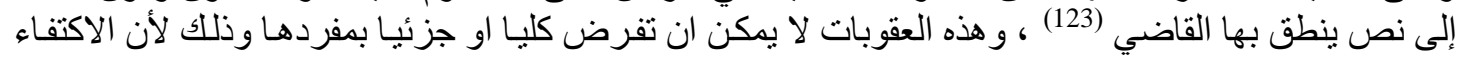

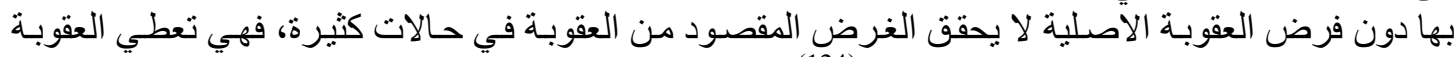

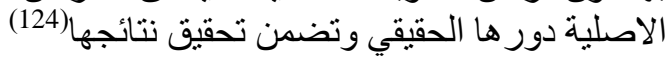

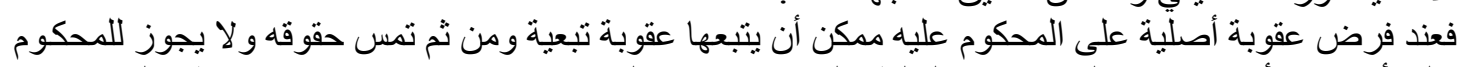

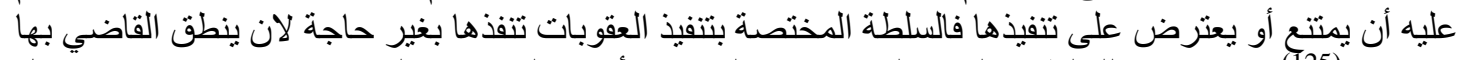

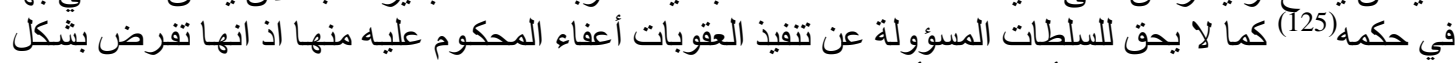

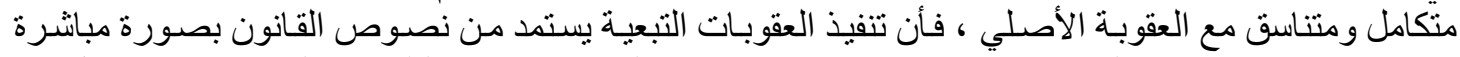

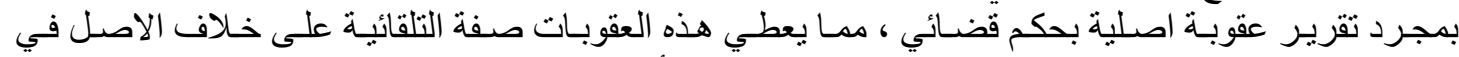

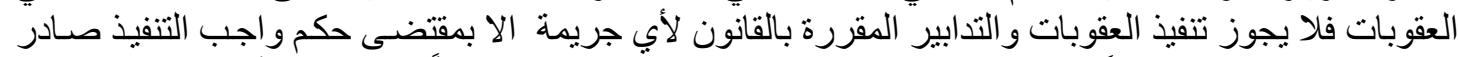

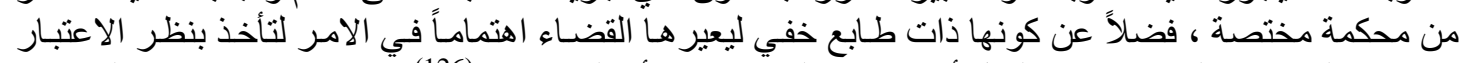

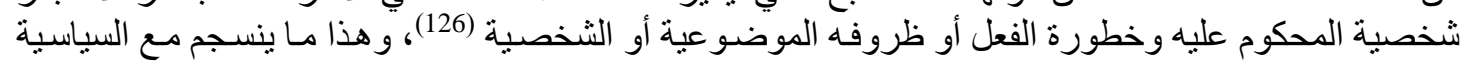

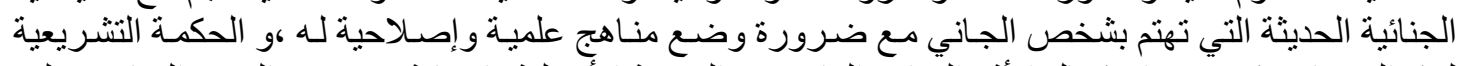

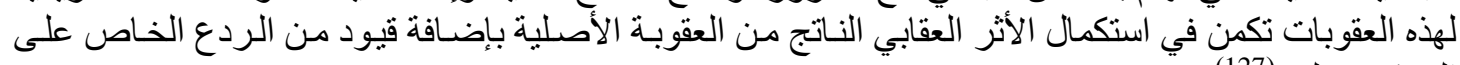
المحكوم عليه (127)

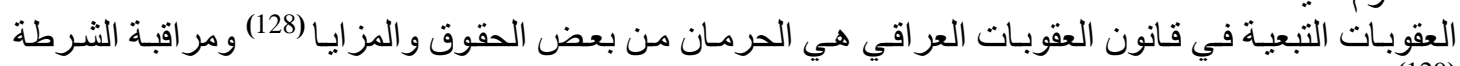

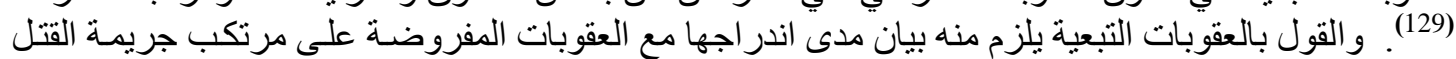

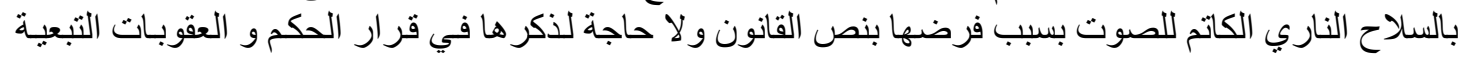

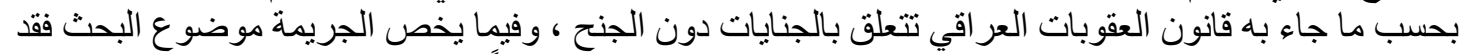

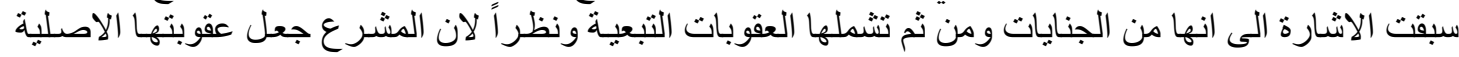

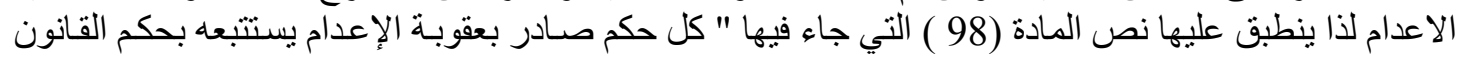

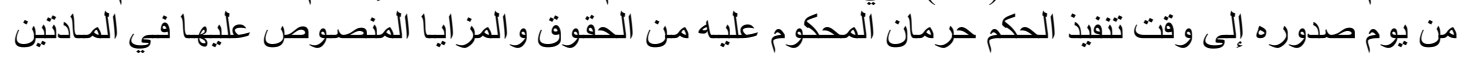




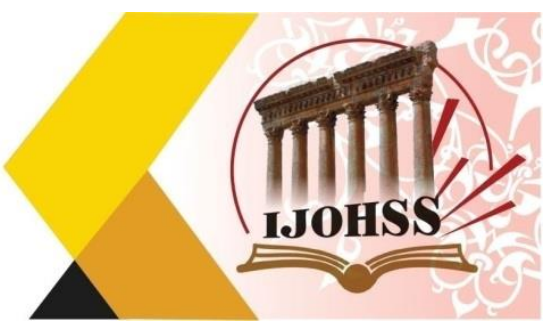

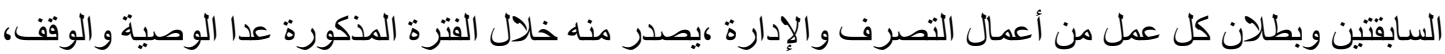

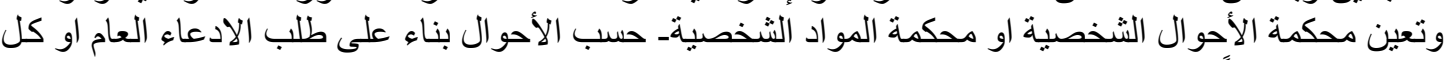

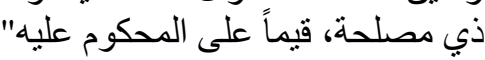

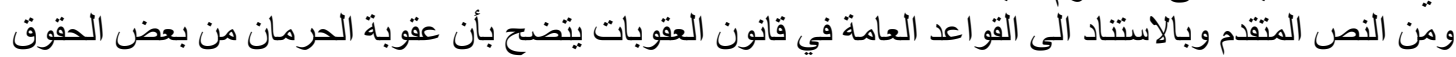

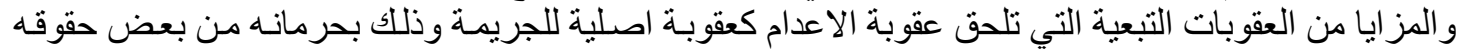

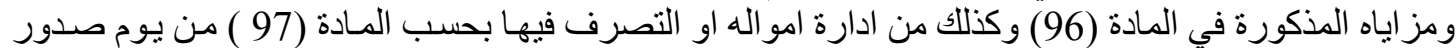

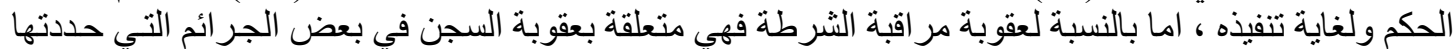

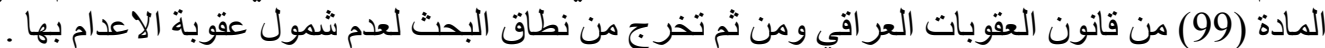

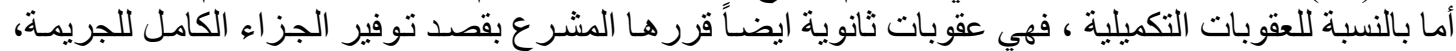

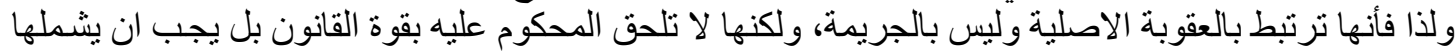

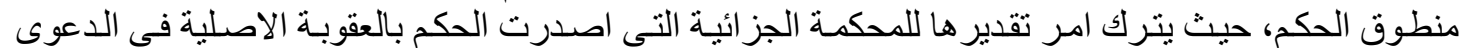

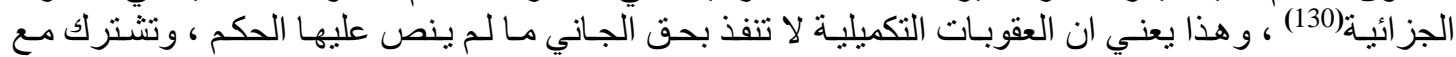

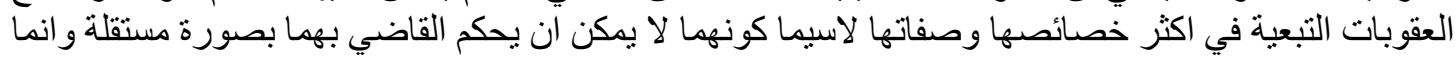

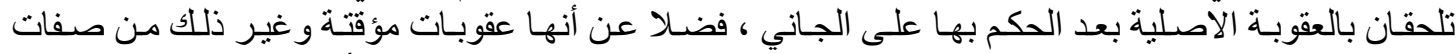

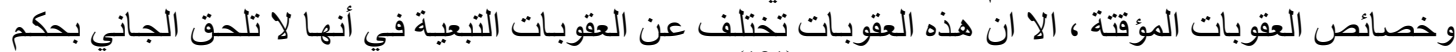

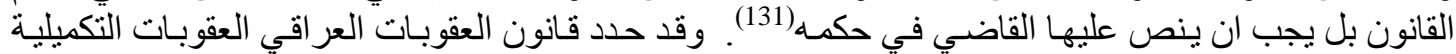

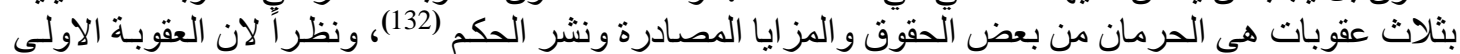

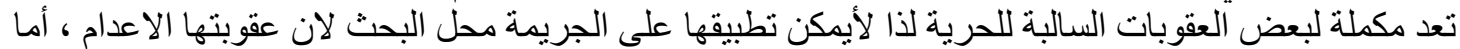

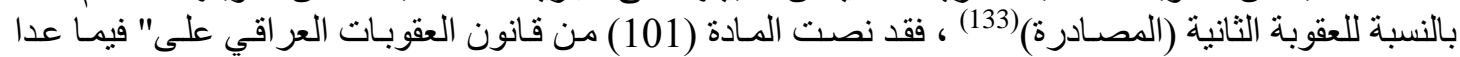

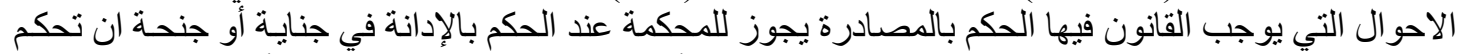

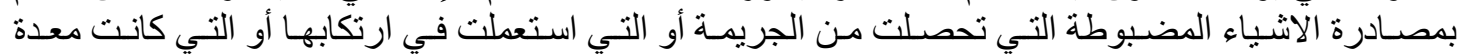

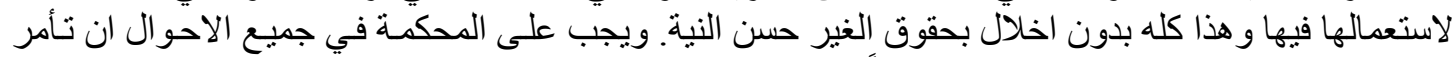

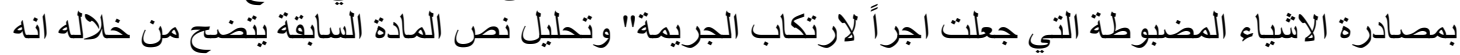

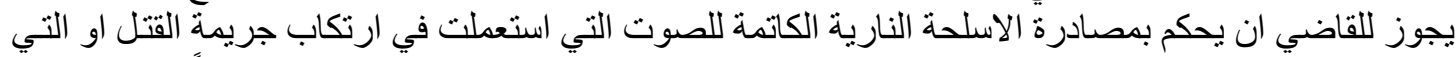

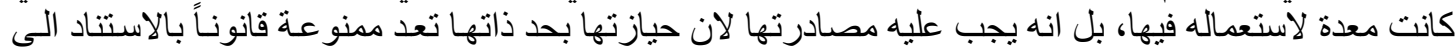

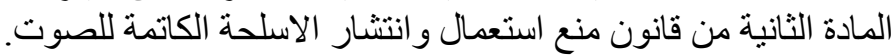

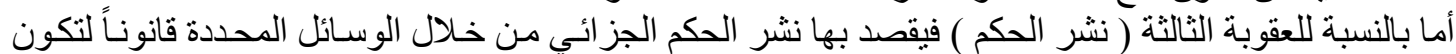

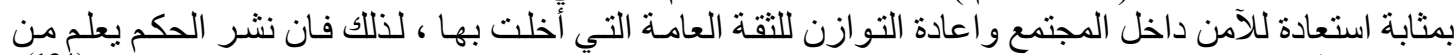

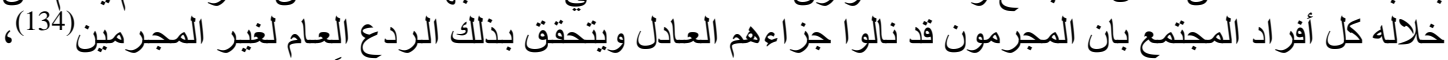

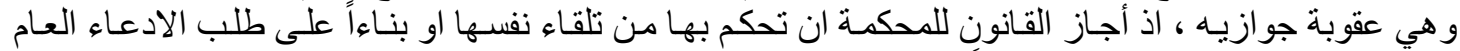

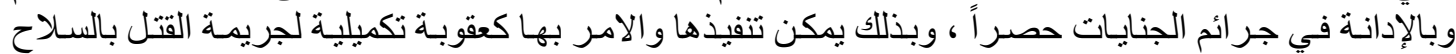

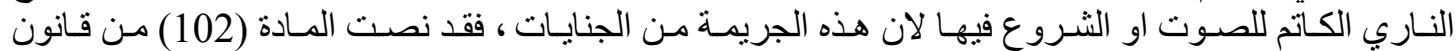

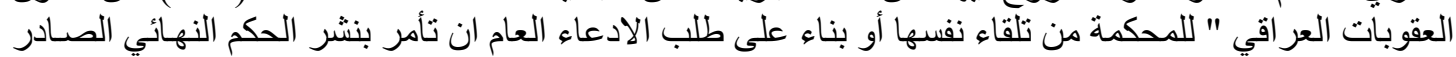

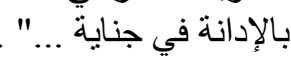

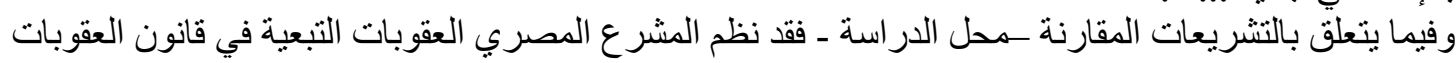

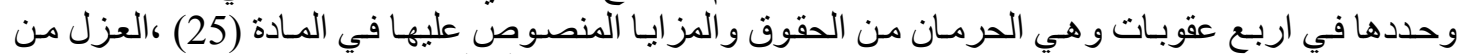

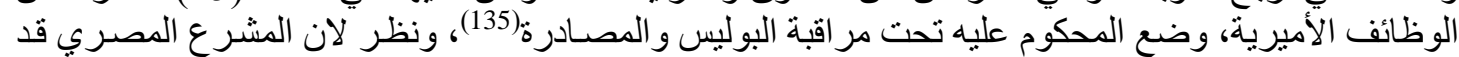

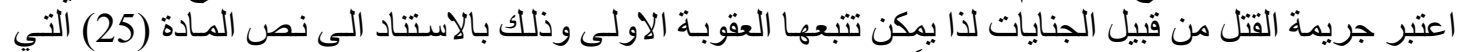

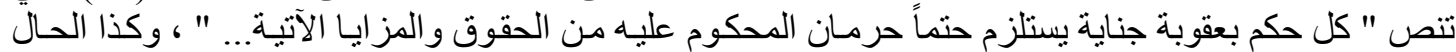

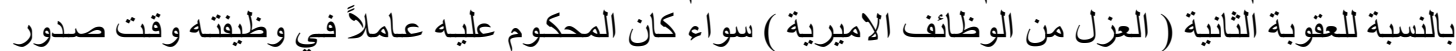

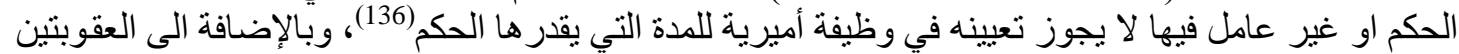

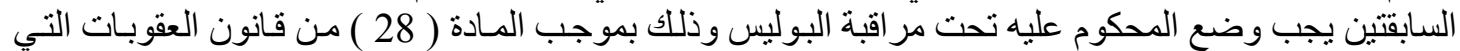

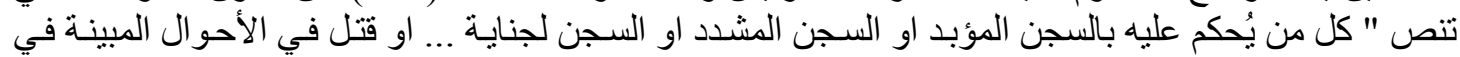




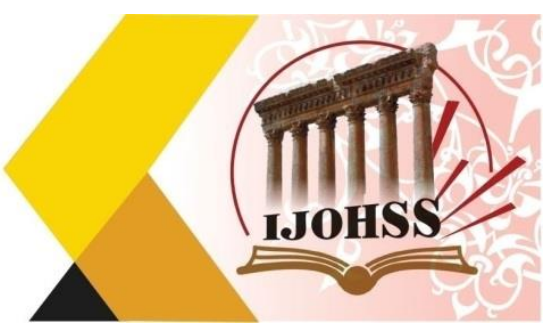

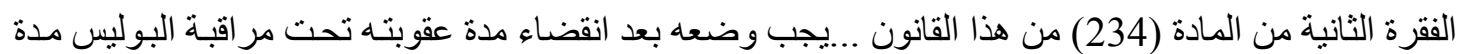

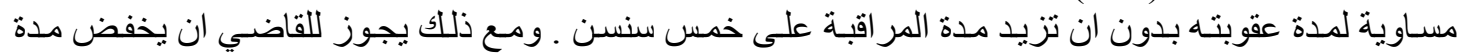

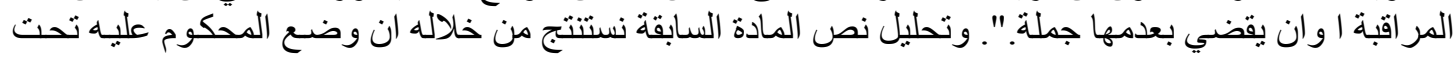

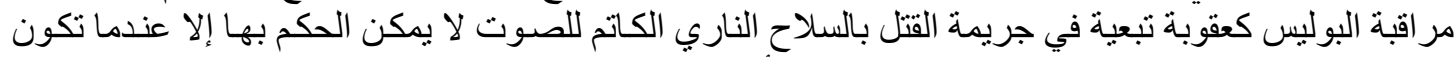

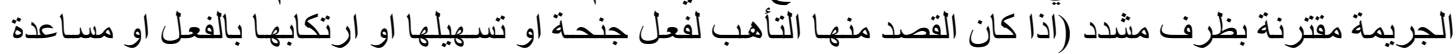

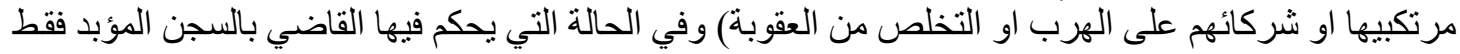

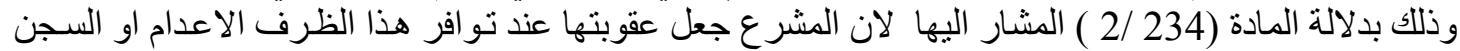

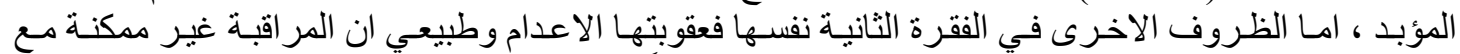

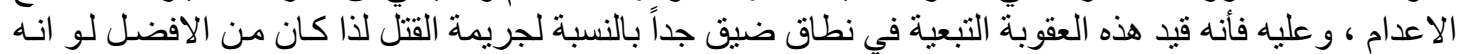

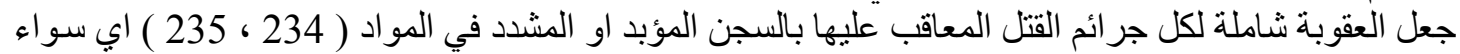

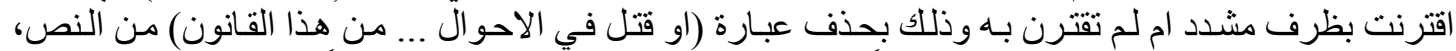

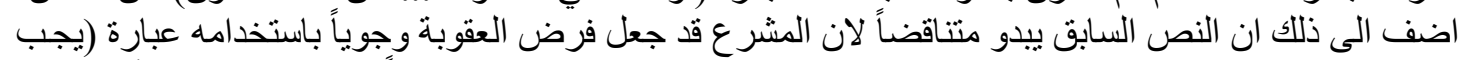

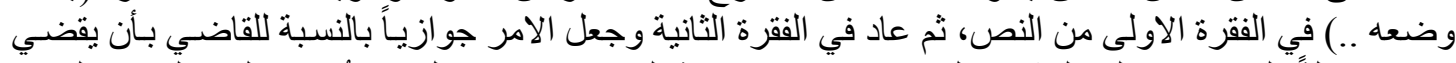

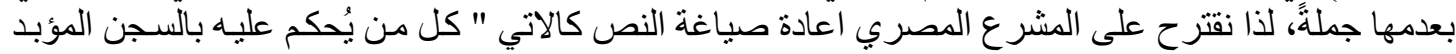

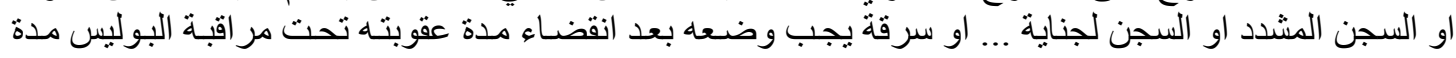

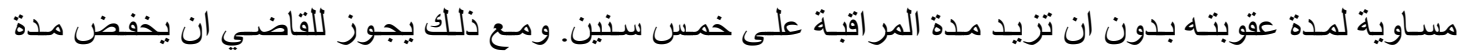

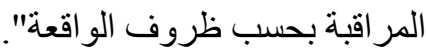

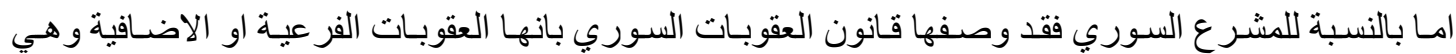

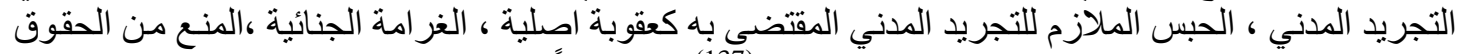

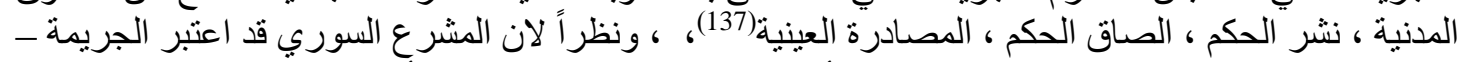

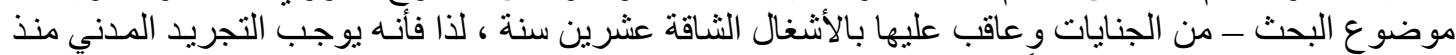

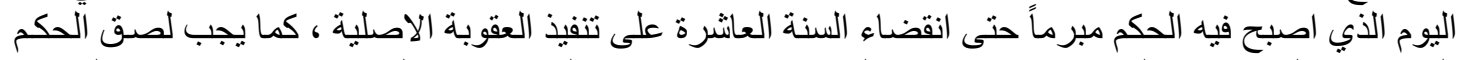

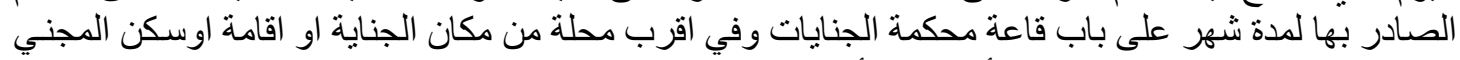

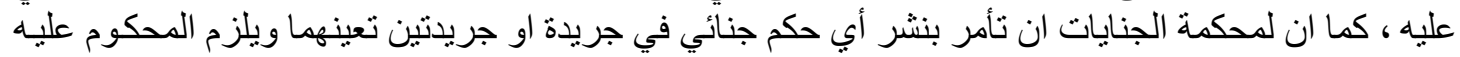

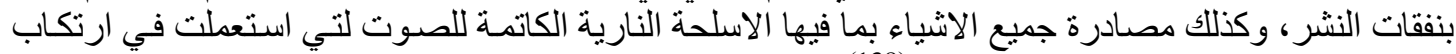

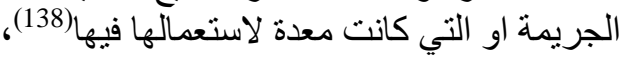

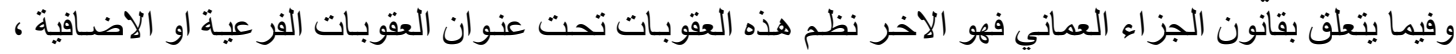

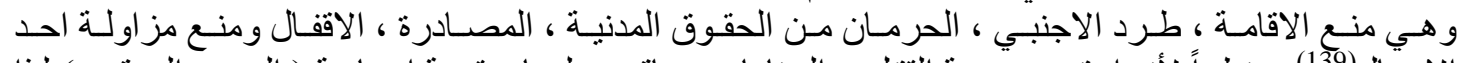

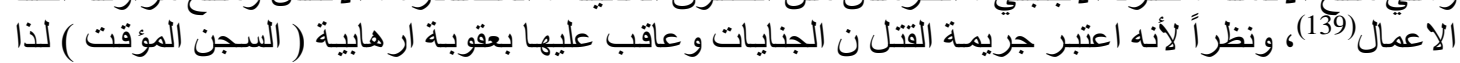

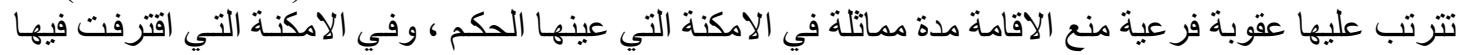

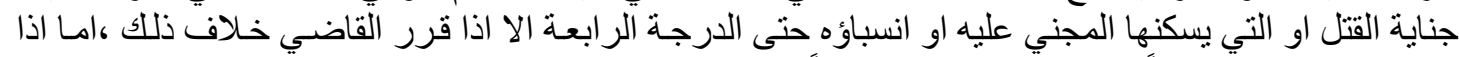

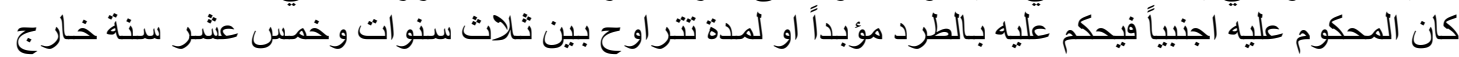

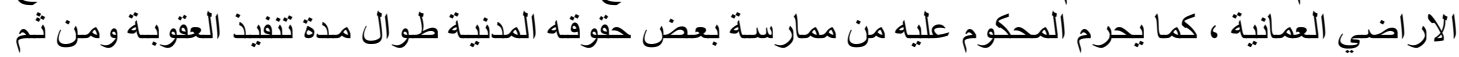

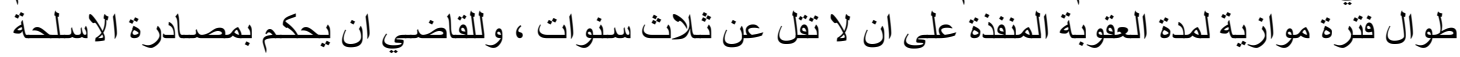

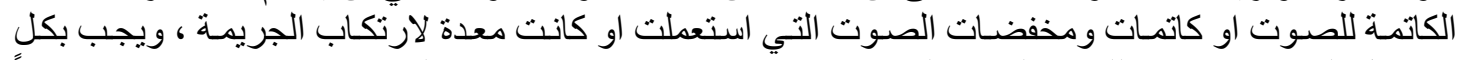

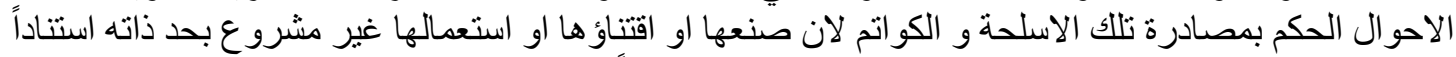

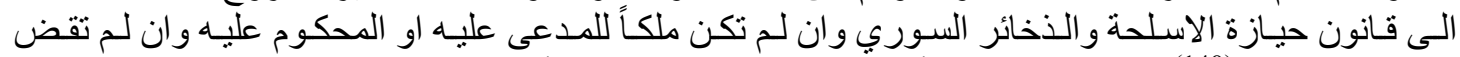

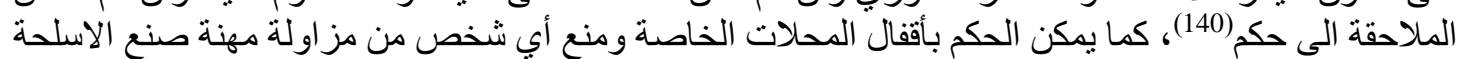

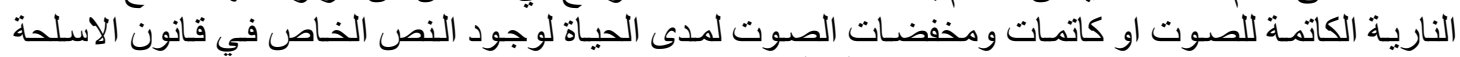

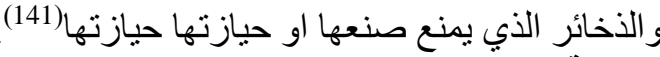
الخاتمة النائر

بعد ان انتهينا من كتابة بحثنا الموسوم " جريمة القتل بالسلاح النـاري الكاتم للصوت ـ در اسـة مقارنة " توصلنا الى النتائج و المقترحات الاتية: 


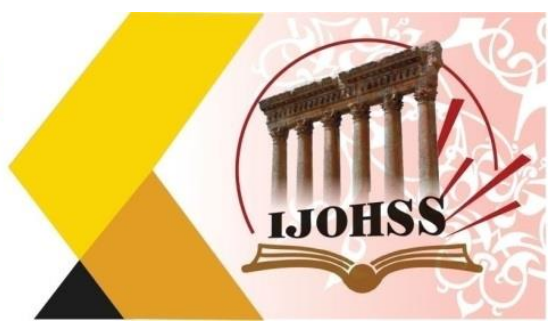

1-يمكن تعريف جريمة القتل بالسلاح الناري الكاتم للصوت بانها " از هاق روح انسان عمدا من قبل انسـان اخر 1اولاًا : النتائج :

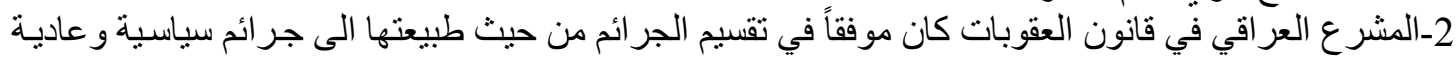

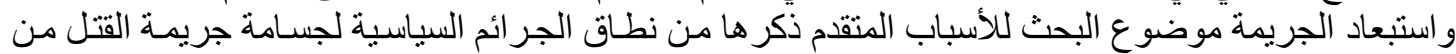

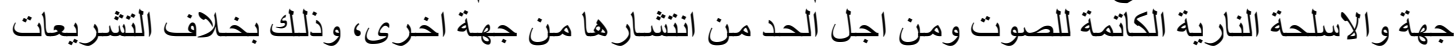

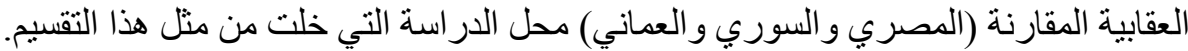

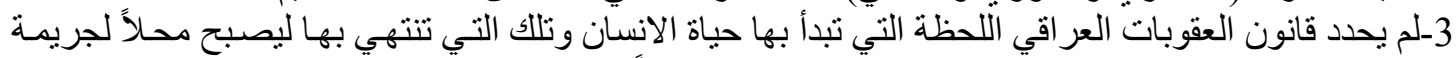

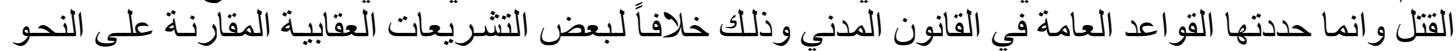
الذي سبق بيانه في ثنايا البحث.

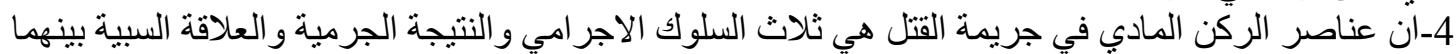

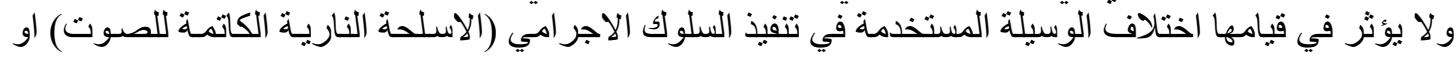

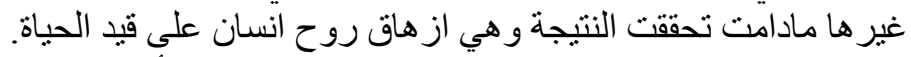

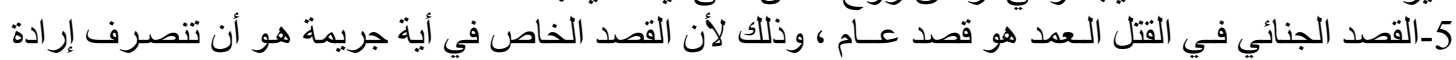

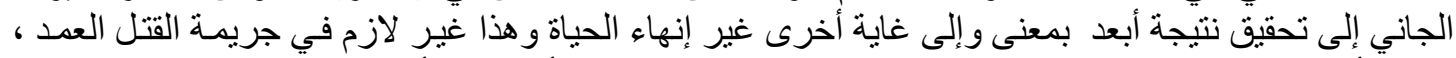

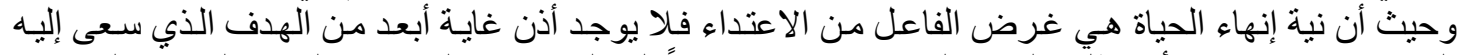

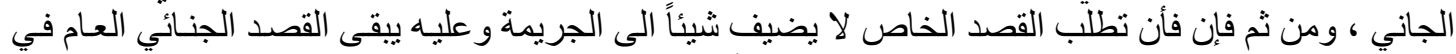
جريمة القتل العدد بالسـلاح النـاري الكاتم للصـوت او بأية وسيلة اخرى في نطاق القصد العام بعنصـريه العلم

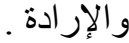

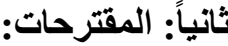

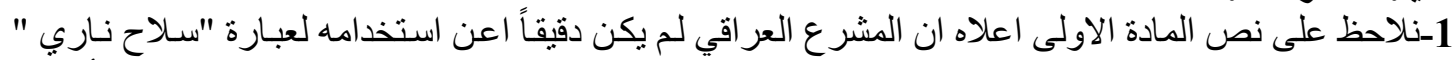

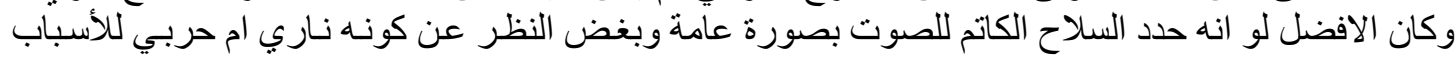

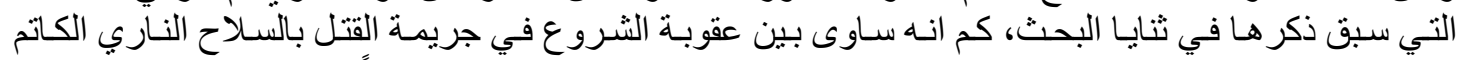

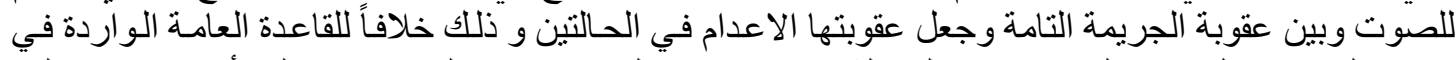

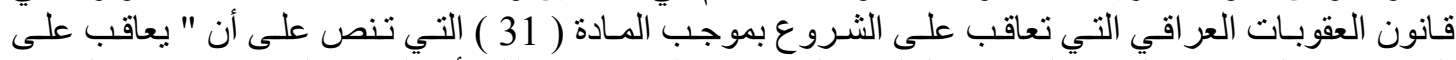

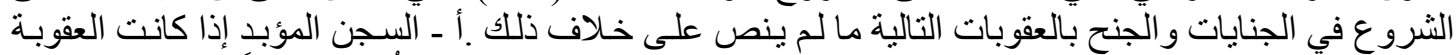

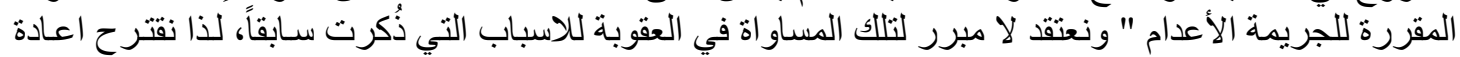

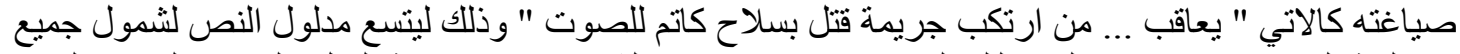

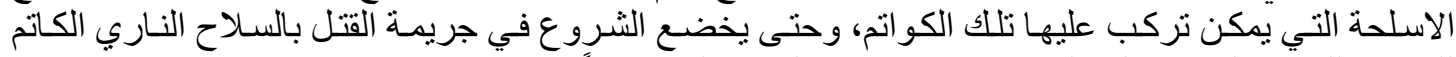

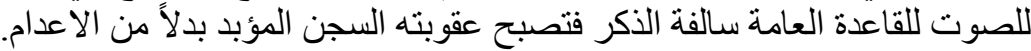

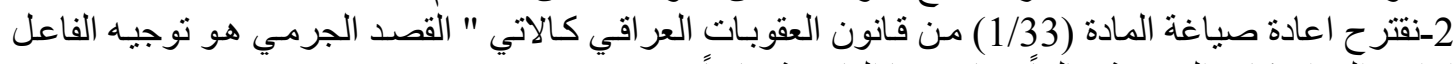

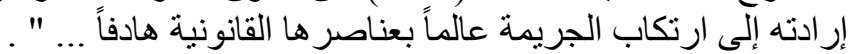

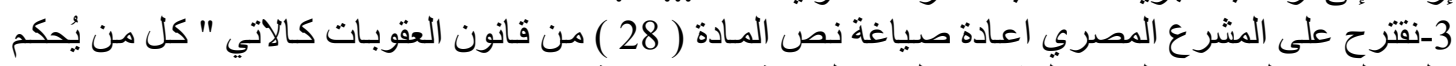

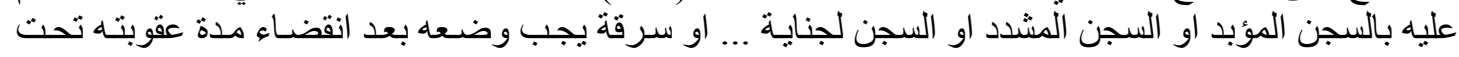

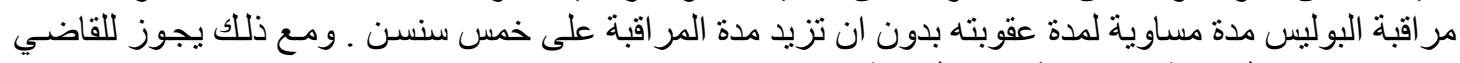

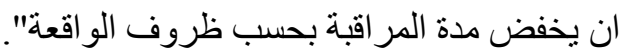

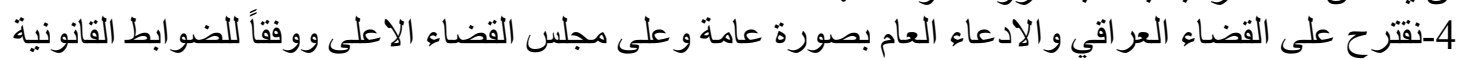

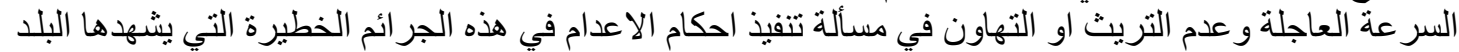
، مع بقاء عدد كبير من المحكومين بالإعدام لا ينفذ بهم الحكم لسنوات طويلة، رغم صدور قرأ فرار الحكم بالإعدام. 


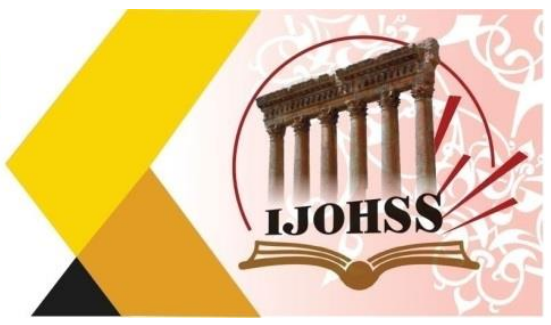

3. الفيروز أبادي مجد الدين بن يعقوب ، القاموس المحيط ، ج1 ، نوبلس للطباعة و النشر ، بيروت ، 2006 ، ص 290.

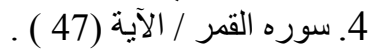

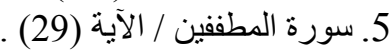

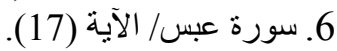

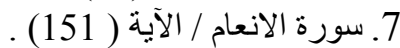

8. احمد مختار عمر ، معجم اللغة العربية المعاصر ، عالم الكتب، القاهرة ، 2008 ،ص222.

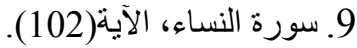

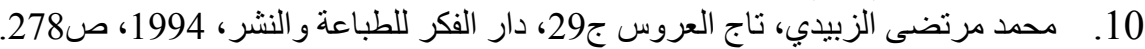

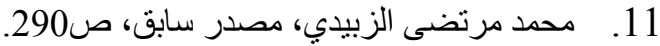

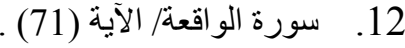

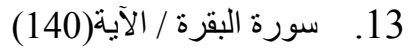

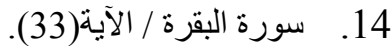

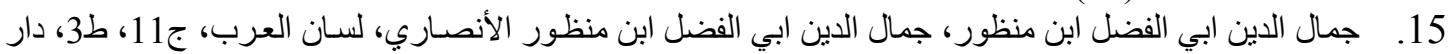

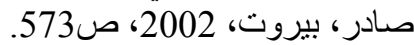

16. سورة لقمان/ الآية(19).

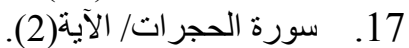

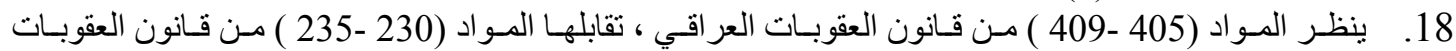

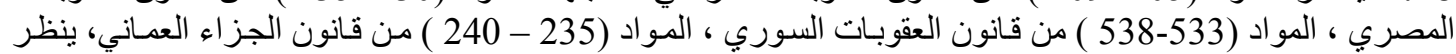

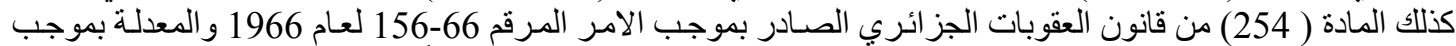

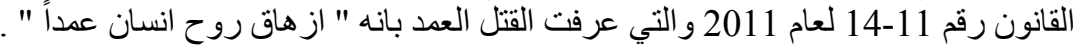

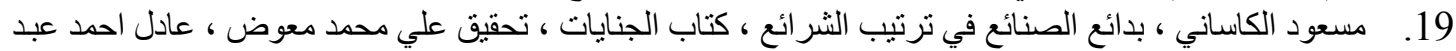

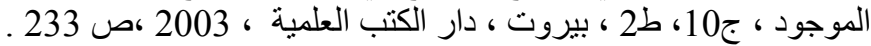

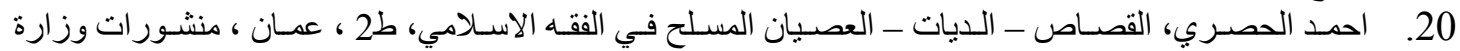

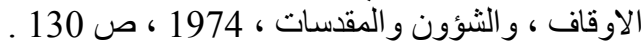

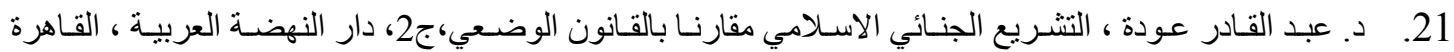
(1980، 190

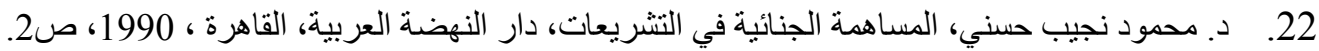

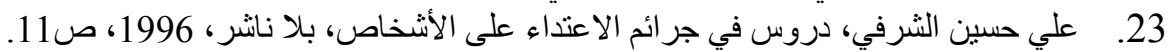

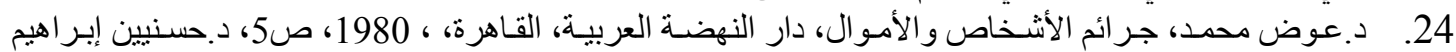

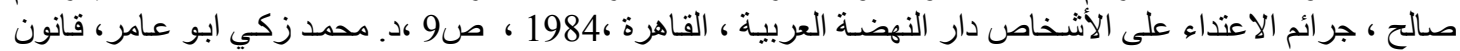

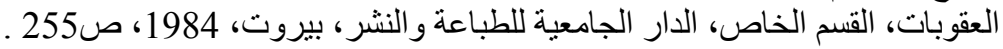

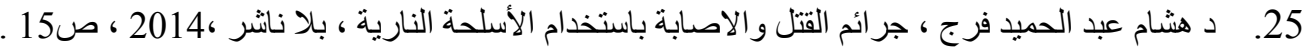

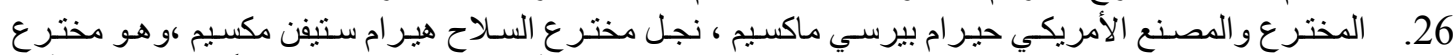

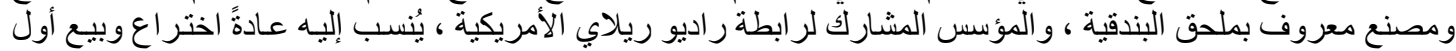

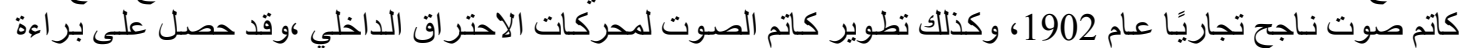

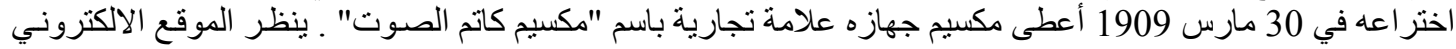

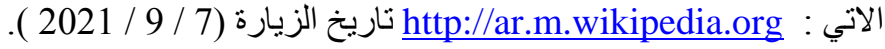

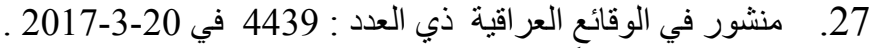

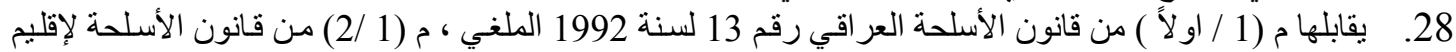
كردستان رقم 16 لسنة 1993 ، (القسم 3/1 ) من سلطة الائتلاف المؤقتـة المنحلة رقم(3) لسنة على الأسلحة الملغي.

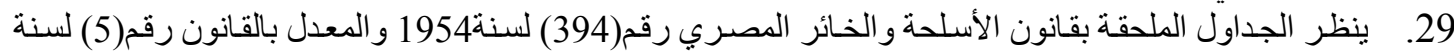
2016، منشور في جريدة الوقائع المصرية، ذي العدد 53 / مكرر في 8 / يونيو / 1954. 


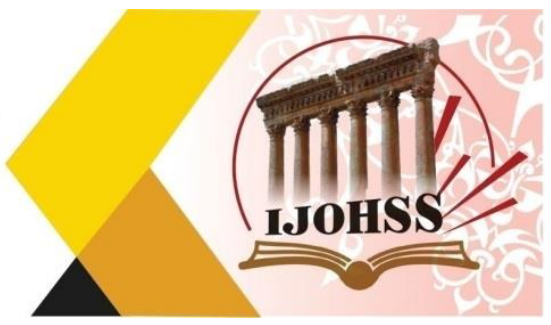

30. أضيف الجدول الخامس بموجب قانون التعديل رقم 5 لسنة 2019 ، منشور في جريدة الوقائع المصرية ذي العدد

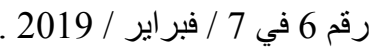

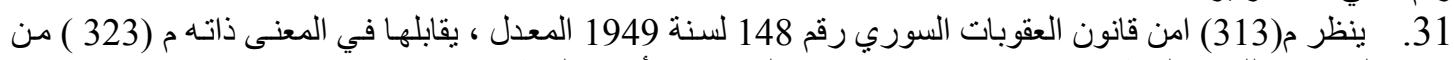

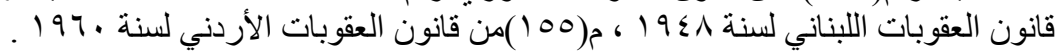

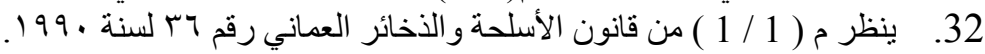
33.

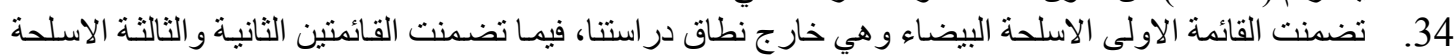

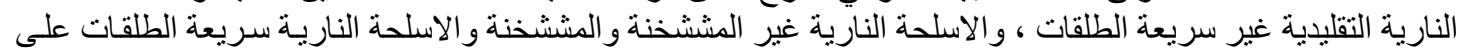

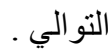

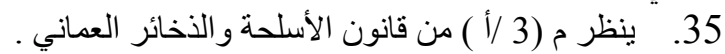

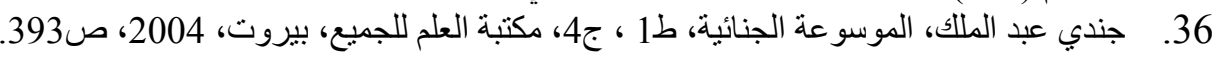

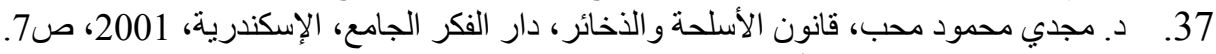

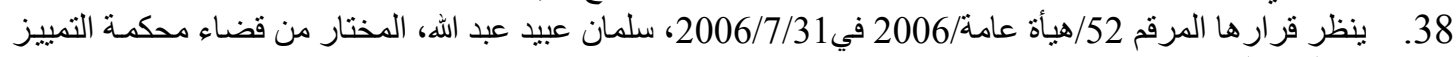

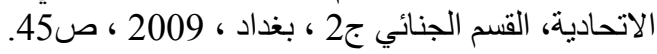

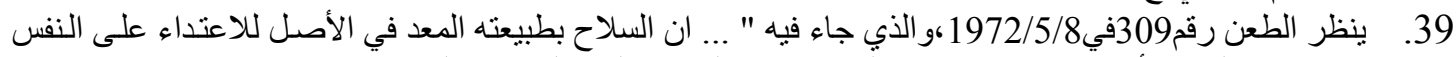

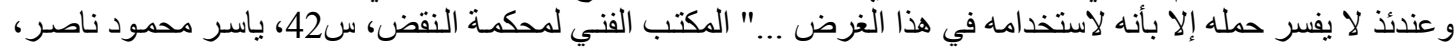

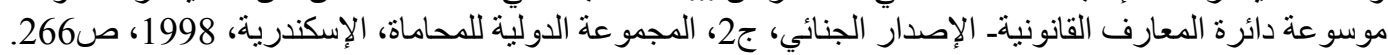
40. للمزيد ينظر د. محمود عبد ربه القبلاوي: المسئولية الجنائية للصيدلي الصئية (دار الفكر الجامعي، الإسكندرية، 2010)

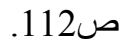

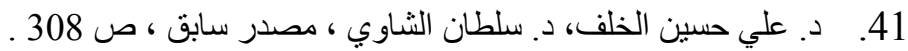

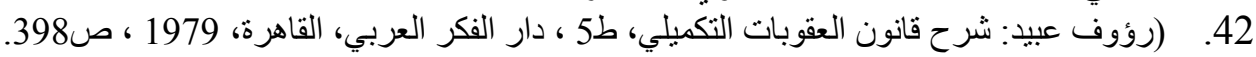

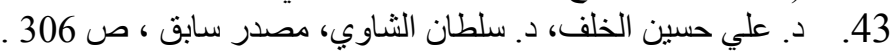

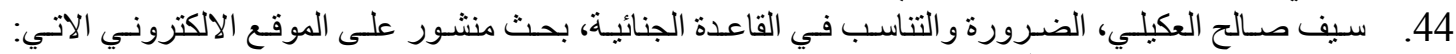
(تاريخ الزيارة 24https://www.iasj.net

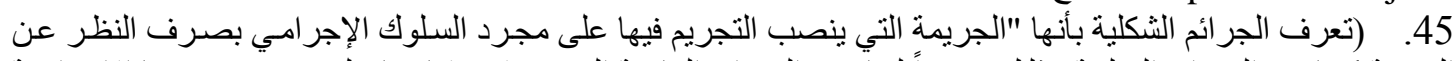

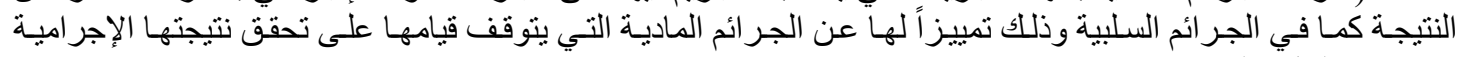

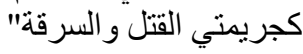
46. د. نسرين محسن نعمة الحسيني، الحماية الجنائية للأطباء-در اسة مقارنة، ط1، بغداد ، الر افد للمطبو عات ،2016، ص ص 1236 47. احمد فتحي سرور، الوسيط في قانون العقوبات القسم العام، ط 6، دار النهضة العربية، القاهرة ، 2015، ص 567-

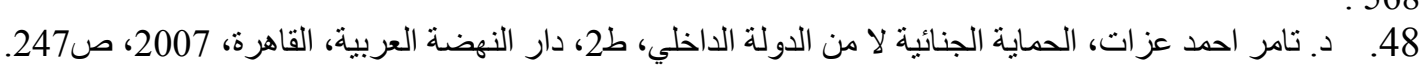

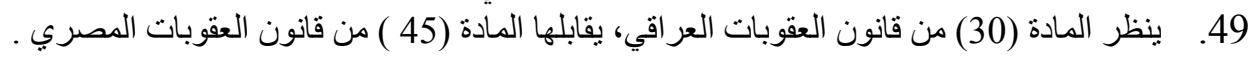
50. Juliusz Piwowarski, Janusz Gierszewsk Security Dimensions, International natlonalstudles. , Poland,no.30-48, p182016 p18

51. د. ادم سميان ذياب الغريري، الأوصاف الخاصـة بـالجر ائم مبكرة الاتمام، بحث منشور في مجلة جامعة تكريت

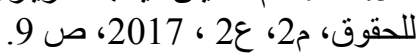

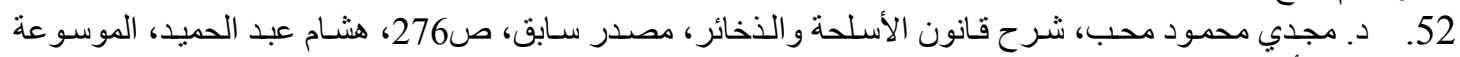

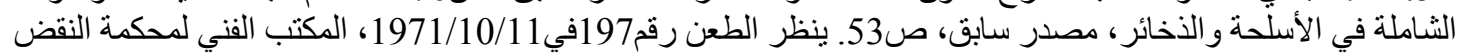

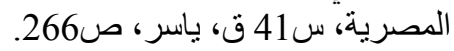

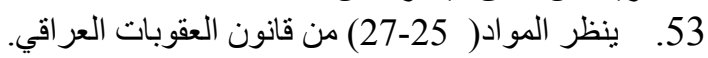

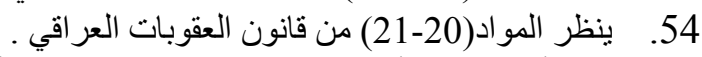

55. ، د. أحمد شوقي أبو خطوة، الجر ائم الو اقعة على الأشخاص في قانون العقوبات، بلا نانشر 1990 ، ص 123. 


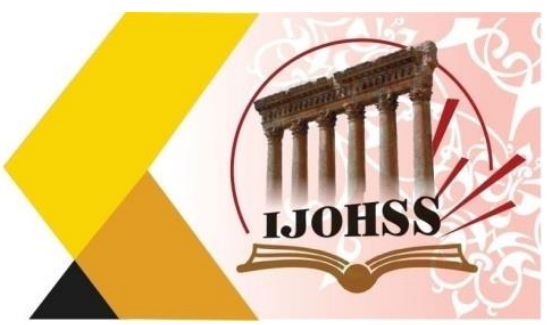

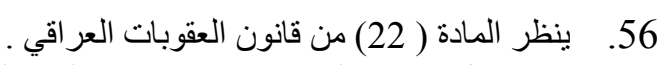

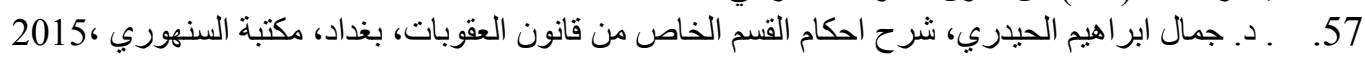

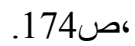

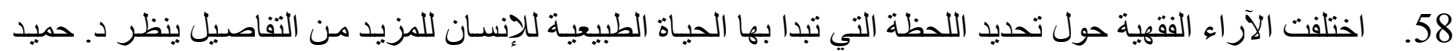

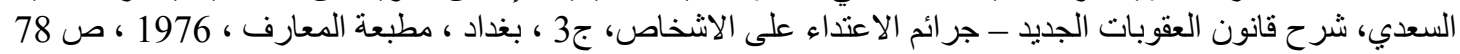

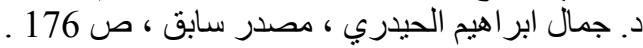

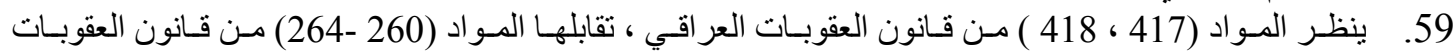

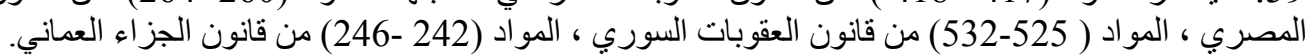

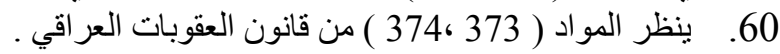

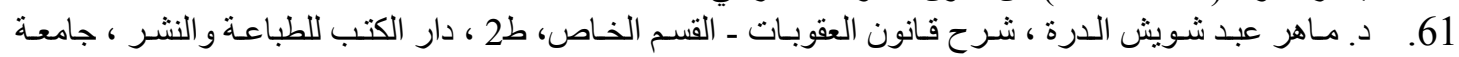

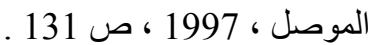

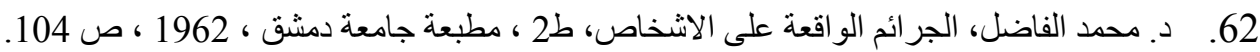

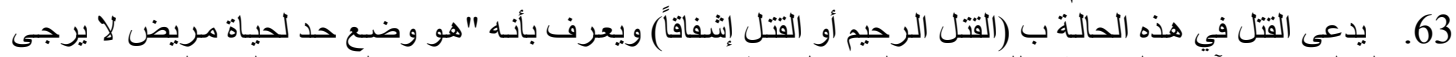

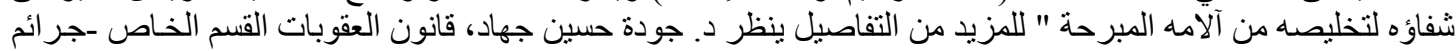

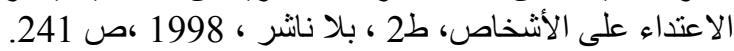

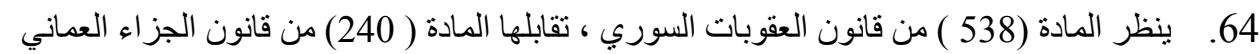

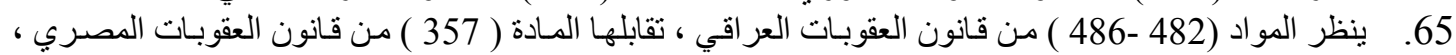

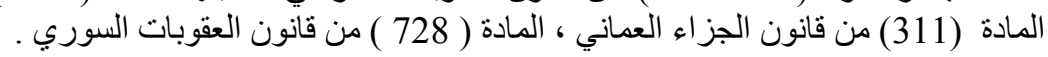

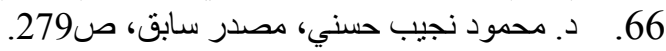

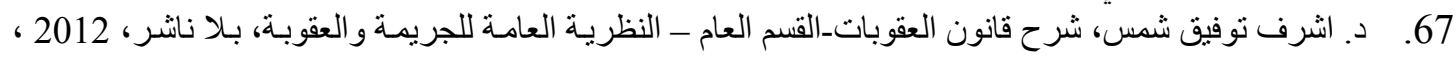

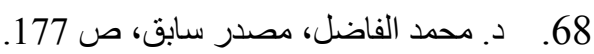

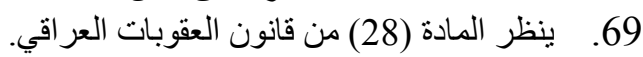

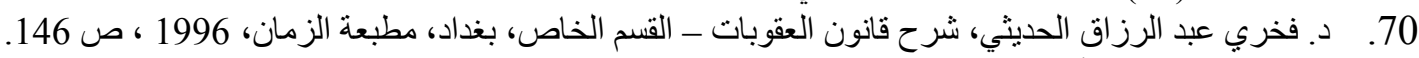

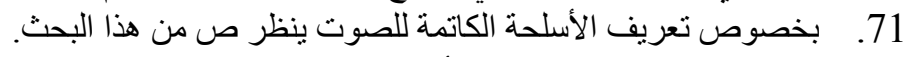

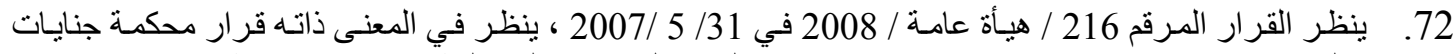

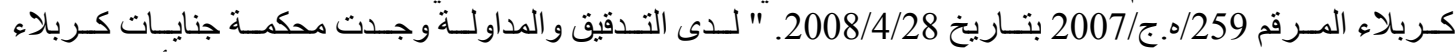

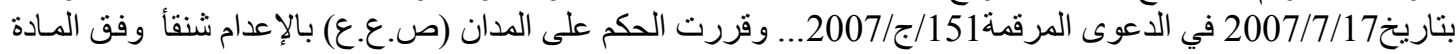

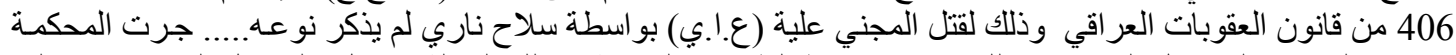

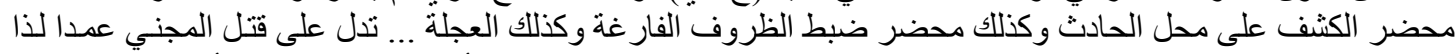

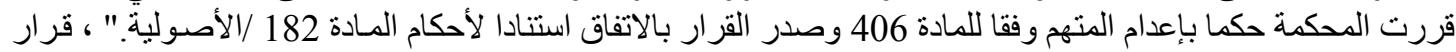

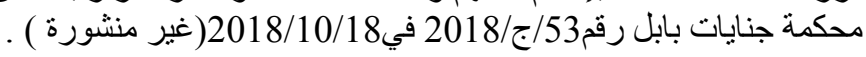

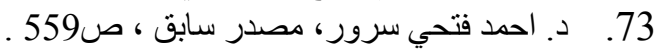

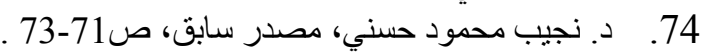

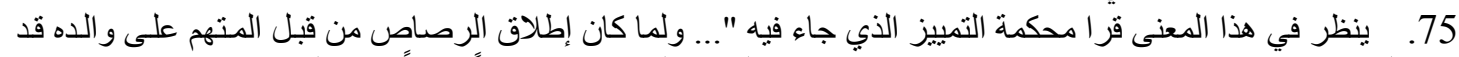

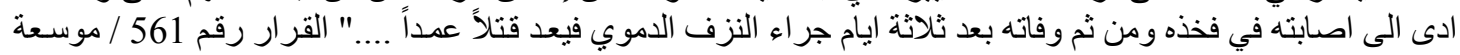

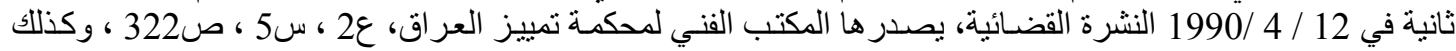

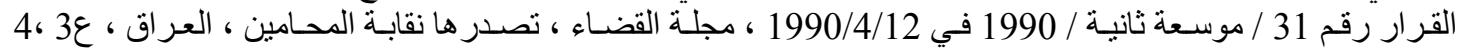

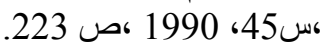

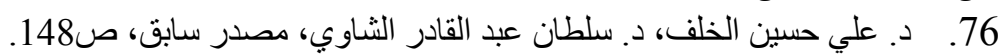

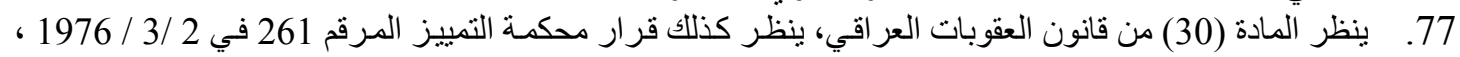

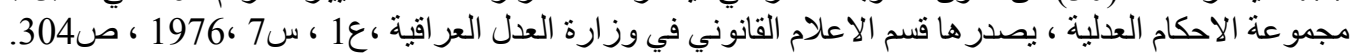

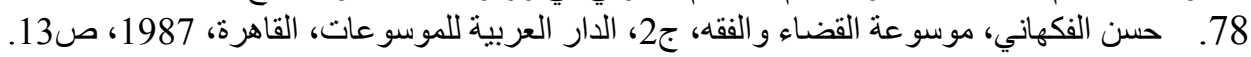




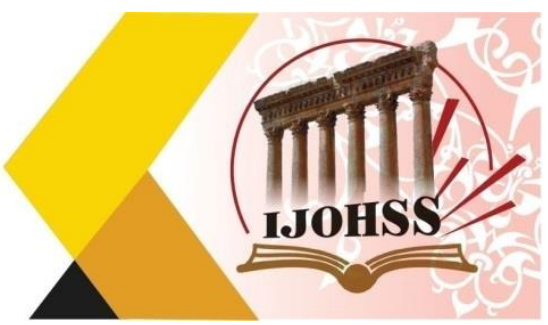

79. تقابلها المادة (45) من قانون العقوبات المصري، المواد ( 199 ، 200) من قانون العقوبـات السوري ، المو اد (86

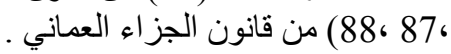

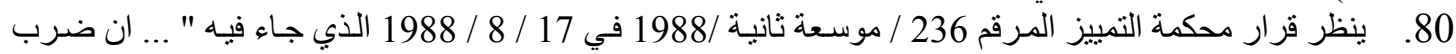

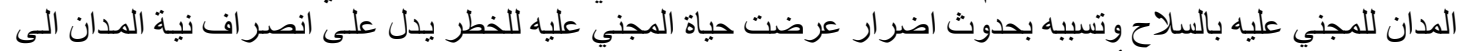

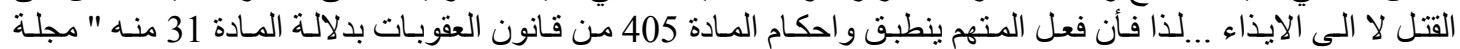

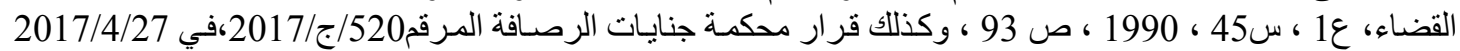

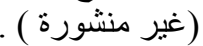

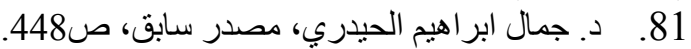

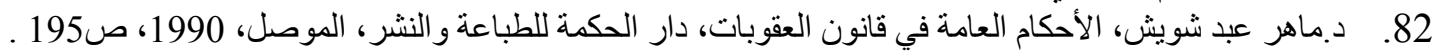

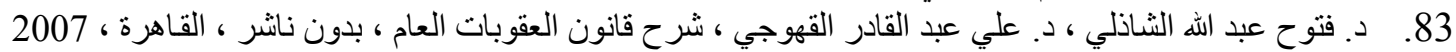
138، (138.

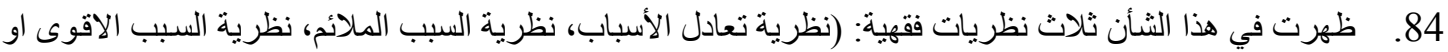

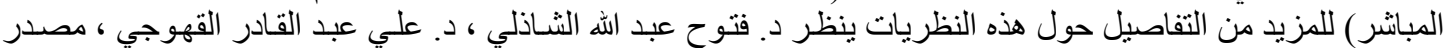

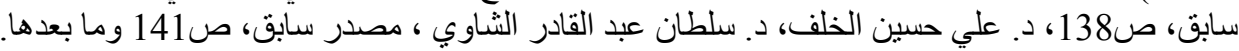

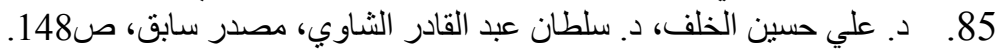

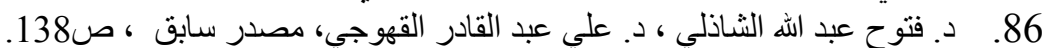

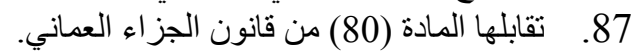
88.

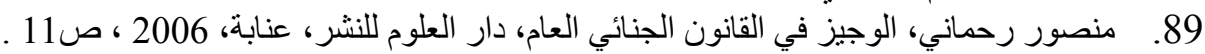

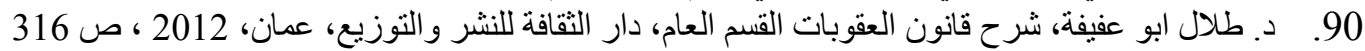

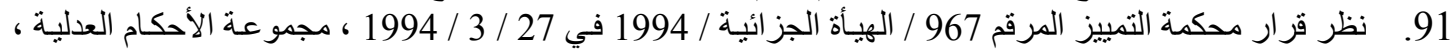

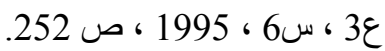

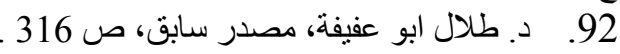

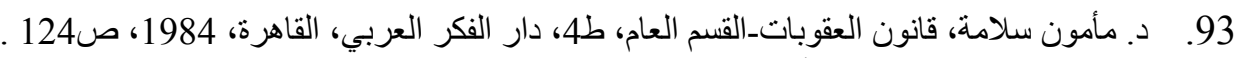

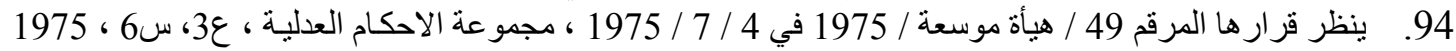

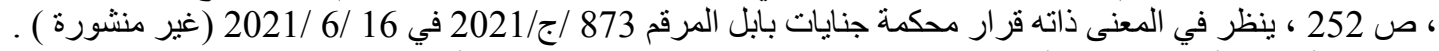

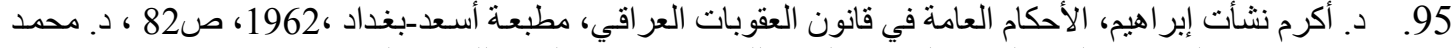

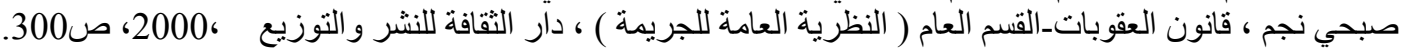

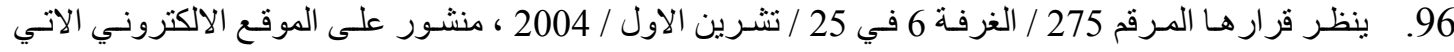
https: Ilwww.stl-tsl.org

97.

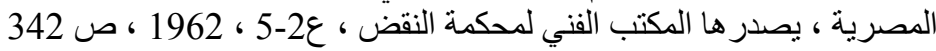

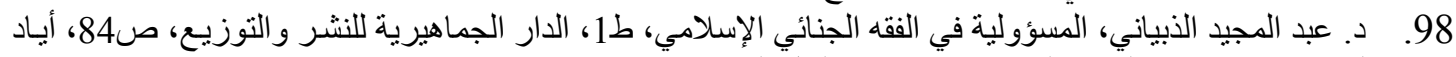

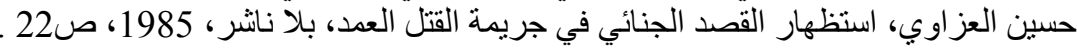

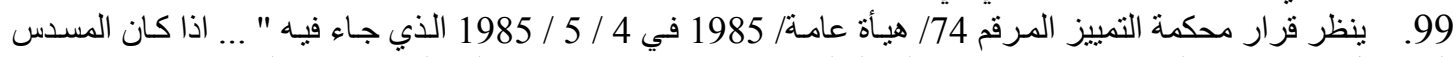

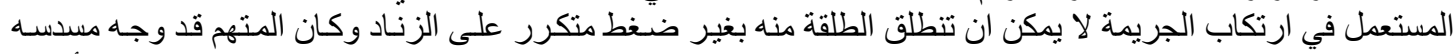

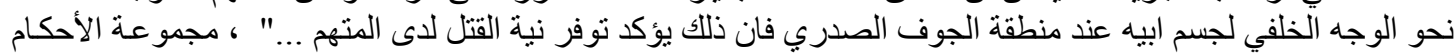

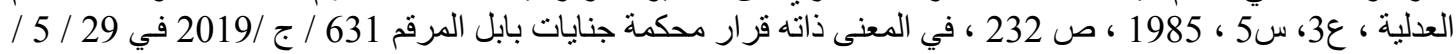

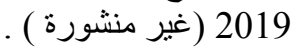

100. محمود طه جلال، اصول التجريم و العقاب في السياسة الجنائية المعاصرة، 2005 ، 2072 ، ص23.

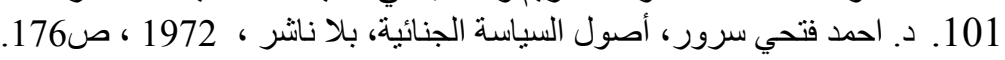

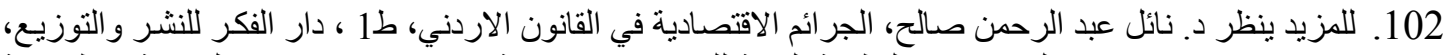

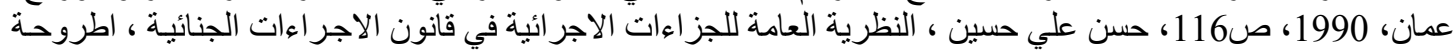

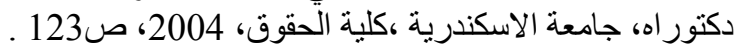




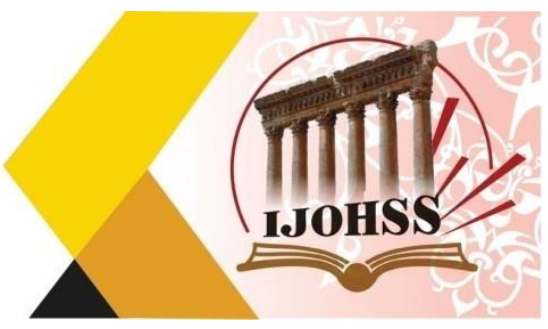

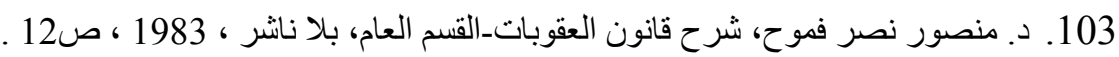

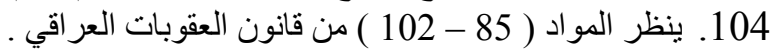

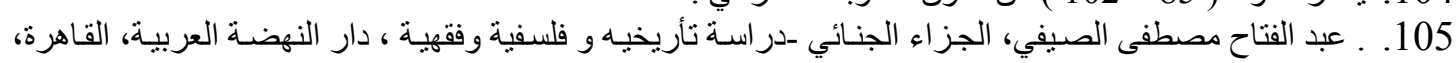

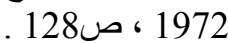

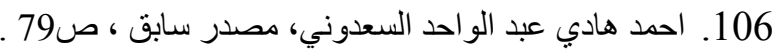

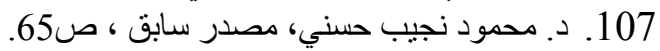

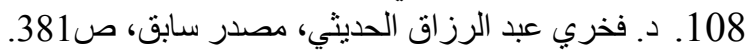

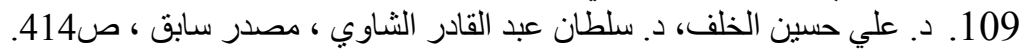

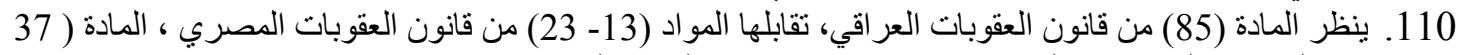

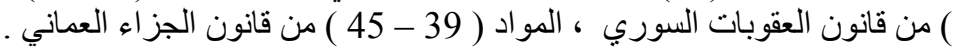

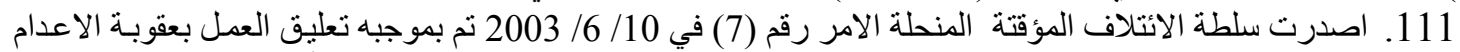

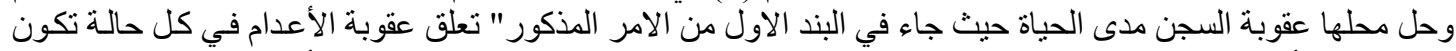

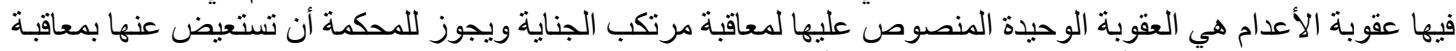

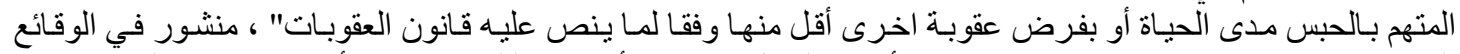

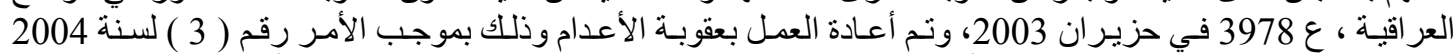

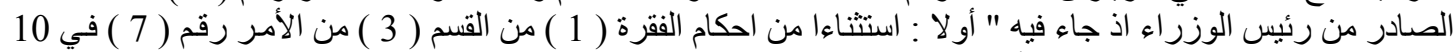

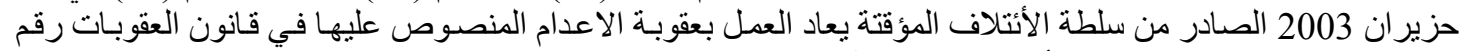

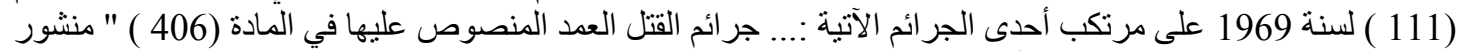

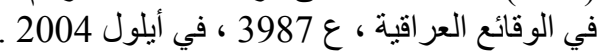

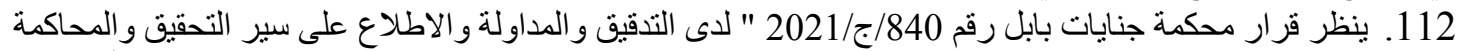

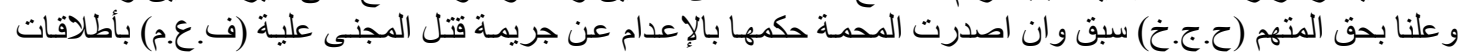

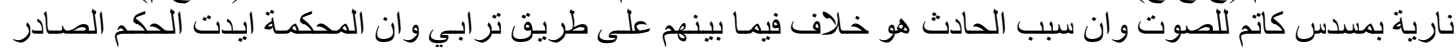

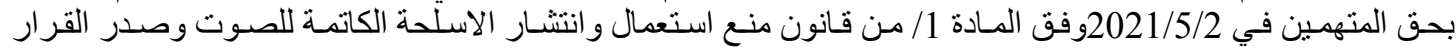

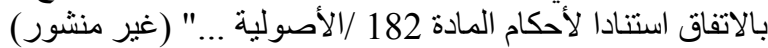

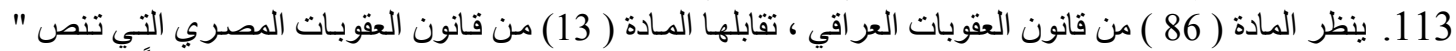

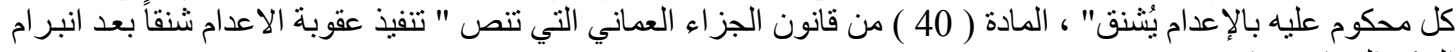

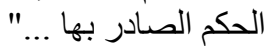

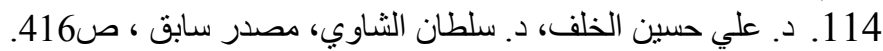

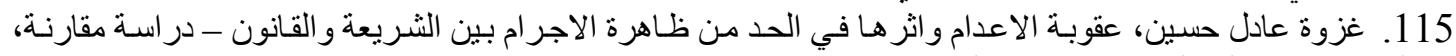

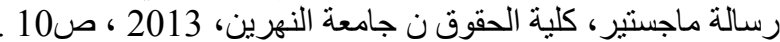

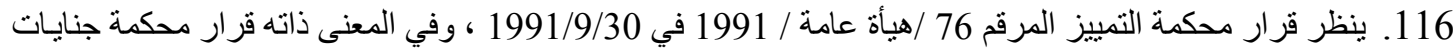

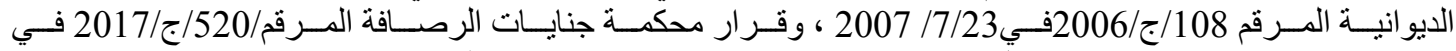

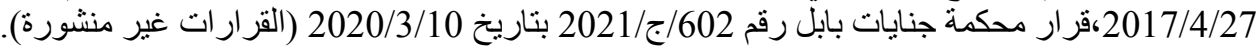

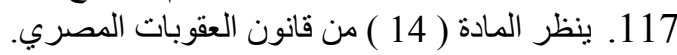

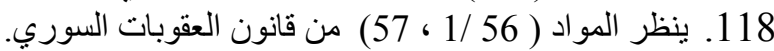

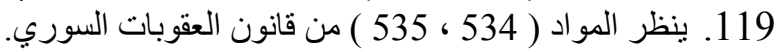

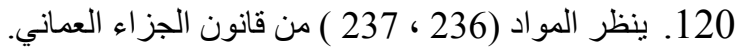

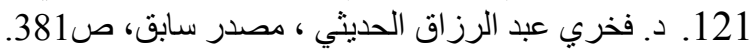
122. تنص المادة (95) من قانون العقوبات العر اقي "العقوبات التبعية هي التي تلدق المحكوم عليه بحكم القانون دون

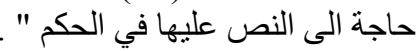

123. (د. محمود نجيب حسني، شرح قانون العقوبات_القسم العام، ط9،دار النهضة العربية، القاهرة، 1595،صائ329

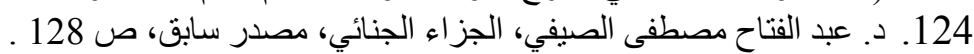
125. د. ددحت محمد عبد العزيز، النظريـة العامـة للعقوبـة والتدابير الاحترازي، دار النهضئة العربية، القاهرة، 2002 219، 


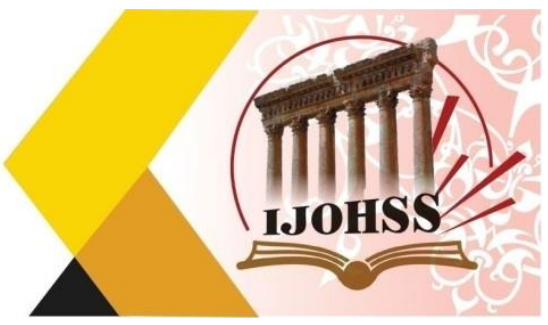

126. د. محمد الرازقي، الدفاع الاجتماعي الجديد، ط1، دار الكتب الجديدة المتحدة، بيروت،

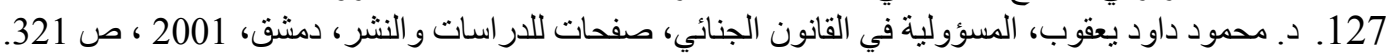

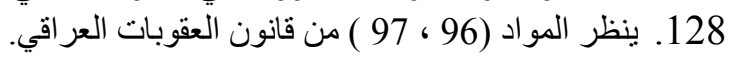
129. ينظر المادة (99) من قانون العقوبات العر اقي.

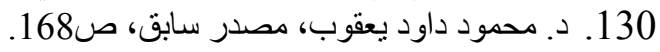

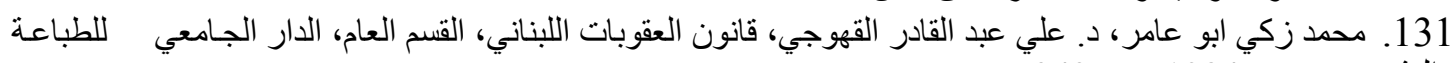

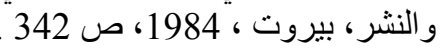

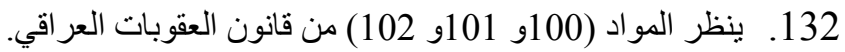

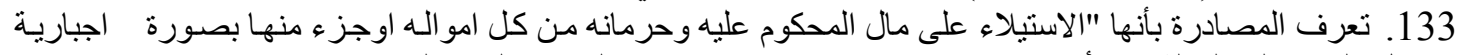

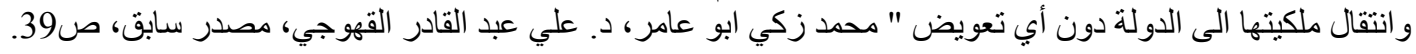

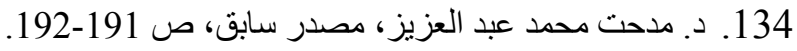

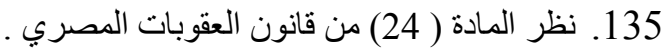
136. 135 ينظر المادة (26) من قانون العقوبات المصري.

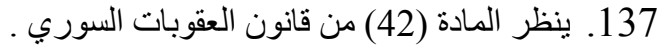

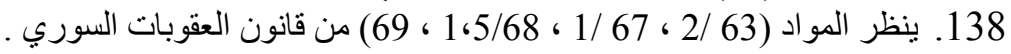
139. ينظر المادة (46) من قانون الجز اء العماني.

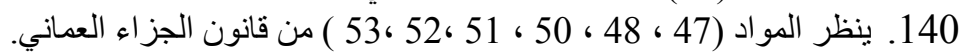
141. ينظر المواد ( 55) من قانون الجزاء العماني . القاًان : المعاجيم 1. الفيروز أبادي مجد الدين بن يعقوب، القاموس المحيط، ج1 ، نوبلس للطباعة و النشر ، بيروت ، 2006 ، 2002.

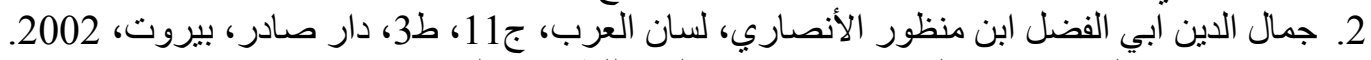

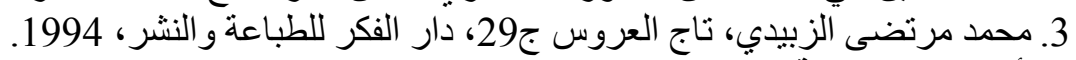
ثانيا:_-الكتب القانونية الزية

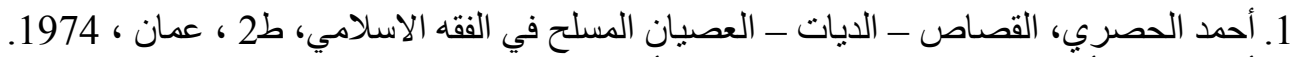

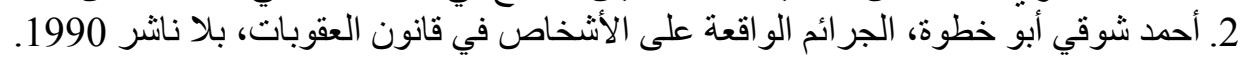

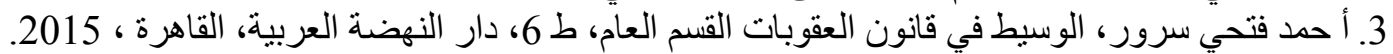

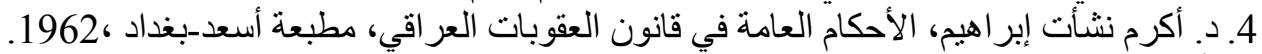

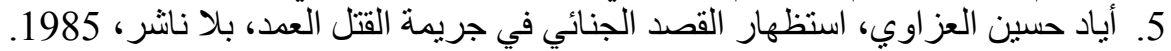

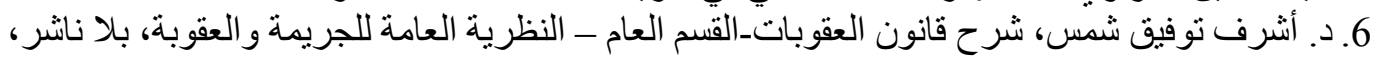
2012 7. تامر احمد عزات، الحماية الجنائية لا من الدولة الداخلي، ط2، دار النائه النهضة العربية، القاهرة، 2007.

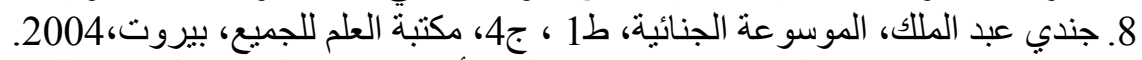

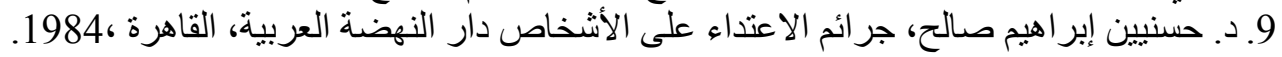

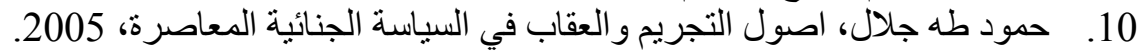

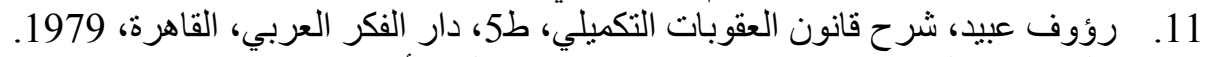

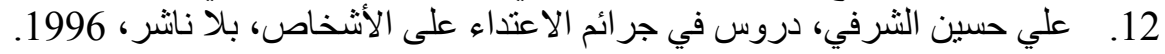

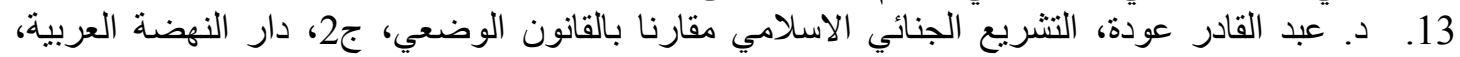

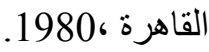
14. د. علي حسين الخلف، د. سلطان الثاوي، المبادي العامة في قانون العقوبات، ط2 القاهره،2010 . 


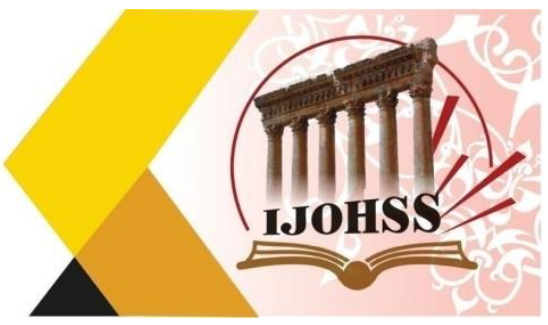

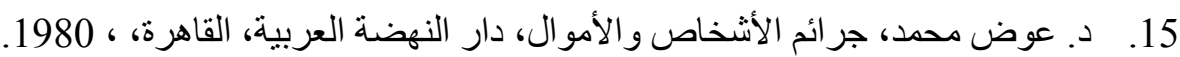
16. 1985 عبد المجيد الذبياني، المسؤولية في الفقه الجنائي الإسلامي، ط1، الدار الإنية الجماهيرية للنشر والتوزيع .1985 ،

17. فخري عبد الرزاق الحديثي، شرح قانون العقوبات ـ القسم الخاص، بغداد، مطبعة الزمان، 1996.

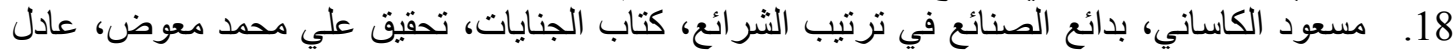

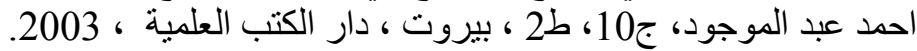

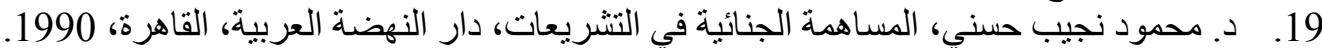

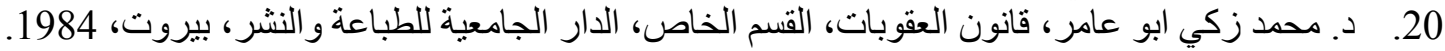

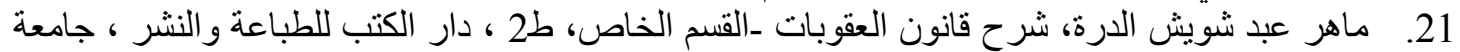

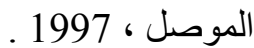

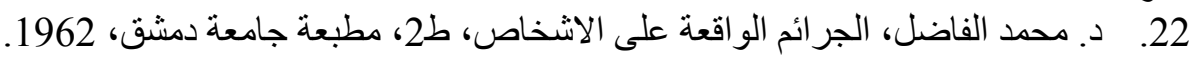

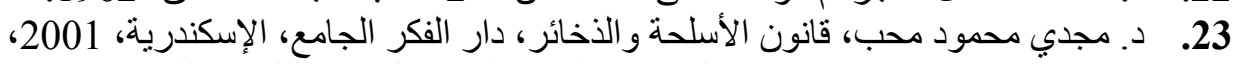

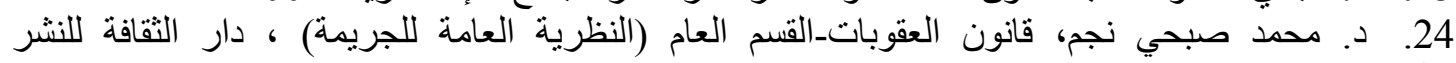

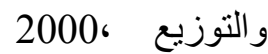

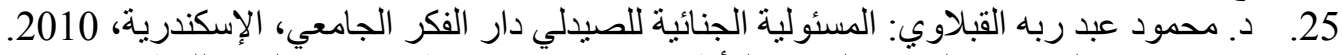

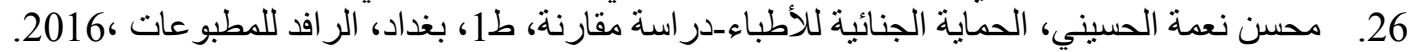

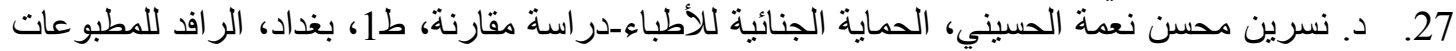
.2016 ،

28. د هثام عبد الحميد فرج، جر ائم القتل و الاصابة باستخدام الأسلحة النارية، بلا ناشر ،2014.

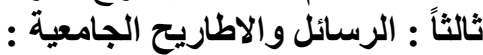

1. أحمد هادي السعدوني ،الحماية الجنائية للادوية الطبية ،در اسة مقارنة ،رسالة ماجستير ، جامعة بابل ، كلية القانون ، .2014

2. غزوة عادل حسين، عقوبة الاعدام و اثر ها في الحد من ظاهرة الاجر ام بين الثريعة و القانون - در اسة

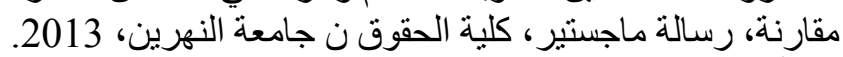

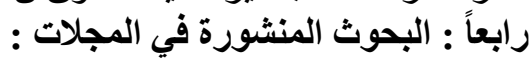

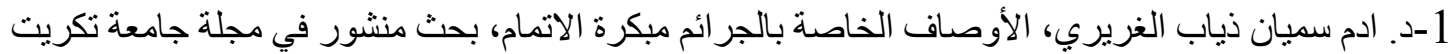

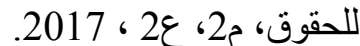

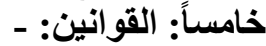

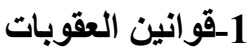
01.قانون العقوبات المصريات العري رقم 58 لسنة 1937.

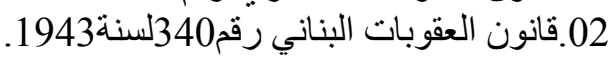

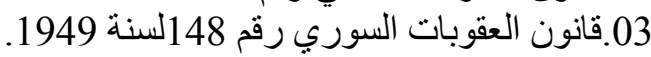

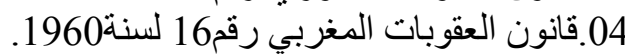

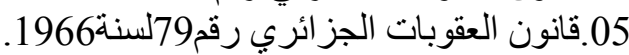

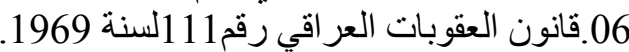
07.قانون الجزاء العماني رقمات العين لسنة 1974.

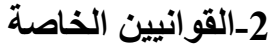

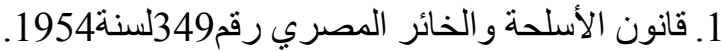

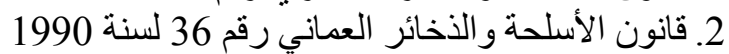

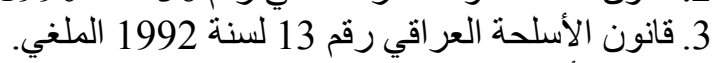
4. قانون الأسلحة لإقليم كردستان رقم 16 لسنة الإنة 1993. 5. قانون الأسلحة و الأخائر السورئرئر رقم 51 لسنة 2001. 


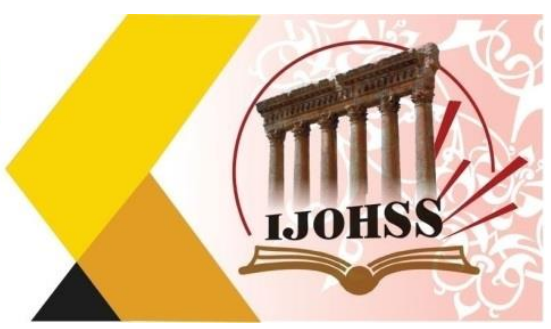

6. امر سلطة الائتلاف المؤقتة المنحلة رقم3 لسنة 2003 الخاص بالسيطرة على الأسلحة الملغي.

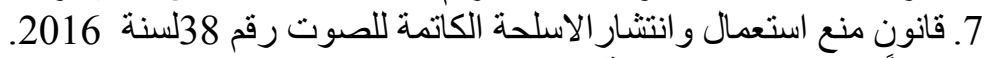
سادساً : المواقع الاكترونية : . http://ar.m.wikipedia.org .01 02. سيف صالح العكيلي، الضرورة والتناسب في القاعدة الجنائية، بحث منشور على الموقع الالكثروني الاتي .hhttps://www.iasj.net : https: Ilwww.stl-tsl.org .03

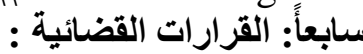

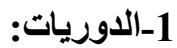

1. مجمو عة الاحكام العدلية، يصدر ها قسم الاعلام القانوني في وزارة العدل العر اقية، ع3، س6 ،1975.

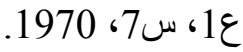

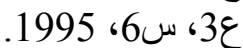

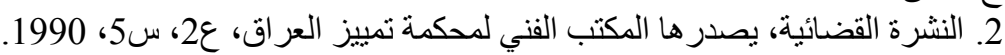

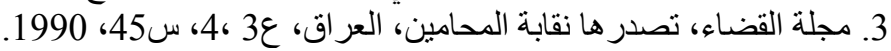

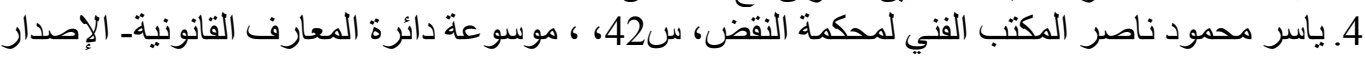

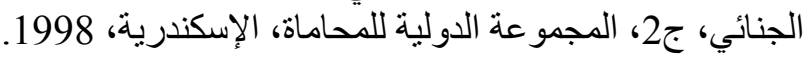
5. سلمان عبيد عبد الله، المختار من قضاء محكمة التمبيز الاتحادية، القسم الجنائي ج2 ، بغداد ، 2009.

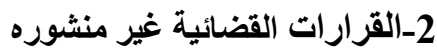

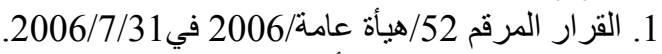

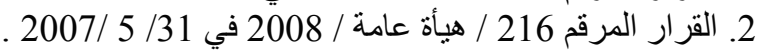

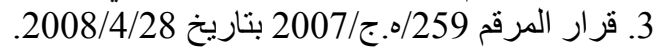

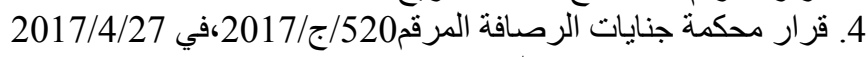

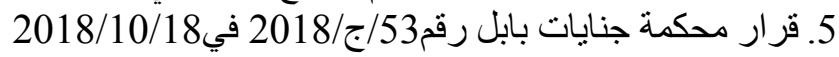

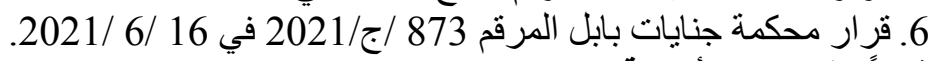

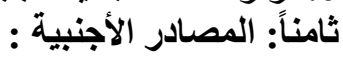

(1) Juliusz Piwowarski, Janusz Gierszewsk Security Dimensions, International natlonalstudles. 